\title{
The Economic Impact of Education Spending: Evidence from Self-Employed Households
}

\author{
By
}

Olivia S. Kim

B.A. Economics

Smith College, 2011

SUBMITTED TO THE SLOAN SCHOOL OF MANAGEMENT IN PARTIAL

FULFILLMENT OF THE REQUIREMENTS FOR THE DEGREE OF

MASTER OF SCIENCE IN MANAGEMENT RESEARCH

at the

MASSACHUSETTS INSTITUTE OF TECHNOLOGY

MAY 2020

(C)2020 Massachusetts Institute of Technology. All rights reserved.

Signature of Author:

Department of Management

February 4, 2020

Certified by:

Jonathan Parker

Professor of Finance

Thesis Supervisor

Accepted by:

Catherine Tucker

Sloan Distinguished Professor of Management

Professor, Marketing Faculty Chair, MIT Sloan PhD Program 


\title{
The Economic Impact of Education Spending: Evidence from Self-Employed Households
}

\author{
By
}

Olivia S. Kim

\begin{abstract}
SUBMITTED TO THE SLOAN SCHOOL OF MANAGEMENT ON FEBRUARY 4, 2020 IN PARTIAL FULFILLMENT OF THE REQUIREMENTS FOR THE DEGREE OF MASTER OF SCIENCE IN MANAGEMENT RESEARCH
\end{abstract}

\begin{abstract}
I examine the consumption and labor decisions of self-employed households when a child goes to college using unique financial transactions data from the linked accounts of small businesses and their owners. Households respond to the increase in education spending by downsizing business production and exiting self-employment. They increase medical and restaurant expenditures and cut back on mortgage payments. While education spending hampers business survival, self-employed parents become wage-earners or enter the gig economy after exiting to meet the financial obligations of sending kids to college.
\end{abstract}

Thesis Supervisor: Jonathan Parker

Title: Professor of Finance 


\section{Introduction}

Paying for college has become a growing financial burden for American households, amid rising tuition costs and student debt. There is an active policy debate on easing this financial burden by making college more affordable and forgiving student debt (Farrell et al., 2019). However, despite recent work on the effect of student debt, there has been relatively little research on the broader economic consequences of out-of-pocket education spending on households. ${ }^{1}$ Understanding the impact of education spending on households that may have limited downside insurance against income risks is a first-order question given the well-established evidence that households lack adequate financial buffer and exhibit "excess sensitivity" of consumption to income shocks (see, for example, Parker et al. (2013)). Are education costs large enough to affect the standard of living of families? And which economic margins are impacted?

Self-employed households provide a unique opportunity to understand the implications of education spending for several reasons. First, self-employed households have a choice between continue running a business and transitioning to wage-earning households. Thus, tracing the response of self-employed households provides an opportunity to examine the job transition channel behind consumption smoothing patterns, an important aspect that has been underresearched in the household finance literature despite the critical role that job mobility plays in life-cycle earnings dynamics (Altonji et al., 2013). Second, these households face higher income volatility and have limited insurance against downside risks relative to wage-earning households (Hombert et al., 2016) as most small business owners are not eligible to collect unemployment benefits upon exiting self-employment. Focusing on this population can show how families that are most predisposed to being impacted by high education costs due to uncertain income streams smooth consumption. Lastly, anecdotal evidence points to small business owner households with student debt being less likely to hire workers and apply for business loans (Headd, 2014). This study can shed light on the broader implication of education spending on business dynamism when a child enters college.

In this paper, I examine the effect of household financial burden from education spending on

\footnotetext{
${ }^{1}$ A notable exception is Souleles (2000) who finds that households do a good job at smoothing consumption. I discuss this paper's contribution relative to Souleles (2000) at the end of this section.
} 
consumption and labor decisions of 150,000 self-employed households. Using unique financial transaction data linking small business checking and credit card accounts to personal checking and credit card accounts of self-employed households, I investigate whether households adjust their labor decisions in response to education spending. Specifically, I document novel stylized facts on how business size and exit rates evolve over a child's age profile, and estimate the elasticity of business spending with respect to the changes in college expenditure to capture the magnitude of this response. I find that education spending has meaningful impact on households along several economically important margins. In particular, households downsize business production, exit self-employment, and change household consumption patterns when a child enters college. Small business owners transition from self-employment to wage-earning or gig economy jobs after exiting self-employment, indicating that households may incur loss in non-pecuniary benefits of small business ownership.

Testing the economic impact of education-born financial burden is challenging due to data limitations that complicate measurement. To address this challenge, I collaborate with a large U.S. financial institution - henceforth referred to as my financial services company- to construct a de-identified panel dataset of self-employed households with children. My financial services company provides numerous retail products to small businesses and consumers, including checking accounts and credit cards. I exploit my financial services company's large network of retail clients to identify small business owners who hold both business and personal checking accounts. I link business owners to their family members to recover demographic and financial information, and restrict the sample to relatively comparable self-employed households with children aged between 14 and 25 . This data provide a granular view of the spending patterns of the business owners and their family members.

I document several novel facts using this data. First, the average quarterly spending on education jumps sharply when a child becomes 18 years old, reaches its peak at 21 , and declines past the 21 year-old age mark. The conditional mean of education spending constitutes over $20 \%$ of households' non-durable consumption at its peak. Second, business expenses, revenues, and investment in machinery decline dramatically when a child turns 18 years old, and exit probability from self-employment rises over a child's age profile. These results indicate 
that self-employed households' business performance and career choice are tightly linked to the timing of when households are most likely to incur high education spending. One interpretation of this pattern is that households may be smoothing education expenses by downsizing their business, or by transitioning to more stable wage-earning jobs. I test this hypothesis by estimating the elasticity of business performance and household consumption with respect to the changes in education expenditure.

My identification strategy exploits two institutional features about the U.S. schooling system. First, I exploit the norm that the typical college entering age is 18 and 19; and second, that households are billed their first tuition payments in the second to third quarter transition in the year that a child turns 18-19 because academic terms begin in the fall. I combine these features and use a child turning 18-19 interacted with quarter-transition dummies as instruments for a sudden increase in the propensity to spend on a child's education. I employ two-stage least squares (2SLS) to estimate the elasticity of business spending and household consumption (outcome) with respect to the changes in education spending (endogenous variable). To make comparison across similar households, I limit the sample to households with college-entering dependents (18-19 year olds) and to those with near college-entering dependents (15-17 year olds). Given that my instruments are pre-determined institutional features that are orthogonal to potential business outcomes, and to the extent that households with near college-entering dependents serve as a valid control group as they likely undergo similar business and life-cycle dynamics as those with college-entering dependents, my instruments can estimate the local average treatment effect of education spending. I run several 2SLS diagnostic tests to confirm the validity of my instruments.

I show evidence that households scale down business production and exit self-employment in response to increased education spending. I find that education spending of treated households with 18 or 19 year-old dependents increases by 41 log points relative to control households with 15-17 year-old dependents. Treated households cut back on business expenses and generate lower revenues by $4 \log$ points, and have 0.2 percentage points higher probability of exiting in a given quarter. The elasticity of business spending with respect to education spending is $-8 \log$ points, which implies that a standard deviation increase in the instrumented 
education spending leads to 4 percent decline in business expenses and revenues annually. I find that businesses cut spending on machinery and office supplies the most and utilities the least, indicating that businesses are more likely to cut back on variable expenses relative to fixed costs of operating a business. Overall, self-employed households exhibit economically meaningful intensive (expenses and revenues) and extensive margin (exit) responses to increased spending on a child's education.

I find that households do a good job at smoothing consumption when a child becomes college-going age, and they do so by adjusting the composition of household spending. Household consumption net of education spending increases by 4 log points for treated relative to control group households. Analyzing detailed consumption categories, I find that households increase medical and restaurant expenses, but they reduce spending on groceries and mortgage payments relative to control households. This intratemporal substitution patterns imply that households incur high non-tuition related discretionary spending associated with a child entering college. While households appear to target a fixed consumption budget by reducing some expense categories while increasing others, the net consumption increases during a child's enrollment spell.

I analyze whether business and consumption effects vary by baseline business growth propensities. Given that the timing of a child's college attendance is predictable, self-employed households may strategically adjust firm growth in advance of a child entering college in order to smooth college expenses. I find evidence that self-employed households downsize their business production during a child's college enrollment spell regardless of their baseline growth rates. Therefore, while households may plan for a child's college expense to some degree, I find limited evidence of sufficient pre-planning to smooth education expenses. I analyze heterogeneity in business and consumption effects by comparing households that remain in self-employment relative to those that eventually exit self-employment. I find that consumption smoothing is largely driven by households that remain in self-employment. Both types of households downsize business production, but the magnitude is more pronounced for exiting households.

These findings raise the question of whether the economic well-being of households that 
are induced to exit self-employment worsen after exiting. Households can experience financial difficulty if they're unable to transition to wage-earning jobs quickly, or they may actually be better off if they can earn stable income. I track the financial accounts of households after they exit self-employment and find that household consumption and labor income increase dramatically as soon as they exit. Households also earn side income by participating in the gig economy. Thus, while households respond to the increase in education spending by exiting self-employment, it does not translate into negative consumption impact as they can quickly switch jobs and earn side income.

Overall, these results have several implications. First, inferring economic well-being of the self-employed solely based on consumption patterns may mistakenly lead to a conclusion that the financial burden from education spending is not high enough to affect households because (non-tuition related) consumption can mechanically increase when a child enters college. Given that self-employed households adjust labor margins when a child enters college, it is important to take into account other economic margins that are impacted by education spending. Second, despite the muted impact that education spending has on consumption, downsizing a business or switching jobs can generate loss in non-pecuniary benefits of small business ownership (Hurst and Pugsley, 2011) or disutility from job search. Moreover, whether self-employed households can transition to utility-maximizing wage-earning jobs is an open question. Given that most small business owners are not eligible to collect unemployment benefits, they may not have the financial flexibility to search for an optimal outside option.

This study contributes to two main strands of the household finance literature. First, a growing literature documents that household credit access and financial wealth matter for students' educational outcomes (see for example, Sun and Yannelis (2016); Fos, Liberman and Yannelis (2017); Goodman, Isen and Yannelis (2018)) $)^{2}$. Recent studies capture the cost of education that students face more directly by analyzing the implications of risk-based vs. uniform student loan pricing (Bachas, 2017), or student debt and debt repayment burden (Di Maggio, Kalda

\footnotetext{
${ }^{2}$ See also the following studies in the economics of education literature on the link between credit constraints and students' educational, financial, household formation, marriage market, and occupational outcomes - Keane and Wolpin (2001); Carneiro and Heckman (2002); Belley and Lochner (2007); Lochner and Monge-Naranjo (2011); Lovenheim (2011); Lovenheim and Reynolds (2013); Cooper and Luengo-Prado (2015); Gicheva (2013); Rothstein and Rouse (2011).
} 
and Yao, 2019; Herbst, 2019; Mueller and Yannelis, 2019). Relative to the existing studies that focus on the impact of education costs on student outcomes, this paper examines broader labor market, business outcomes, and consumption behavior at the household-level for the families that bear the cost of education. My results are complementary to those of existing literature, as they indicate that the economic impact of education spending goes beyond the individuals that attend college. ${ }^{3}$

Second, existing studies in household finance examine households' ability to smooth their consumption past transitory income shocks to test the Life-Cycle Permanent Income Hypothesis (LC-PIH) theory. These studies exploit randomized timing of disbursement of economic stimulus (Parker et al., 2013; Broda and Parker, 2014), tax refunds or rebates (Johnson et al., 2006; Baugh et al., 2018; Caldwell et al., 2018), household income or liquidity shocks (Gross and Souleles, 2002; Blundell et al., 2008, 2016; Baker, 2018), or unemployment insurance (Ganong and Noel, 2018), and find that households exhibit excess sensitivity (Hall and Mishkin, 1982) of consumption to transitory income shocks. I contribute to this literature by focusing on the consumption smoothing behavior of self-employed households. Despite the fact that nearly $20 \%$ of the families in the U.S. derive income from self-employment ${ }^{4}$, research on their consumption behavior is limited. Understanding the behavior of these households is crucially important because they are predisposed to being affected by transitory income shocks due to more uncertain and irregular income streams than typical wage-earning households. To my knowledge, this is the first paper to shed light on the consumption smoothing behavior of the self-employed.

The most related study to this paper is Souleles (2000), who uses the Consumer Expenditure Survey and document that households are able to maintain their standard of living (i.e, consumption) as they pay for college. This finding is at odds with a large body of studies that find violation of the LC-PIH. One possible explanation behind this perfect consumption smoothing pattern is that education spending may not have been as burdensome for households

\footnotetext{
${ }^{3}$ Recent papers that examine the link between student debt burden and entrepreneurship document a negative correlation between student debt burden and entry into entrepreneurship (Baum, 2015; Ambrose et al., 2015; Krishnan and Wang, 2018). I complement these studies by showing that the family structure of the self-employed - specifically, having a college-going child - explains business growth and exit.

${ }^{4}$ According to the FRB (2019), 16-24 percent of households received income from self-employment and occasional side jobs in 2018.
} 
as it is now in the time period that Souleles (2000) examines (1980-1993). ${ }^{5}$ Alternatively, families may be adjusting other non-consumption margins to meet the financial obligations for their child's human capital investment. This paper tests these hypotheses by analyzing data from more recent time period when the cost of education rose dramatically, and by examining economic margins beyond consumption. By exploiting the unique feature of financial transactions data from the linked accounts of small businesses and their owners, my findings provide a novel perspective that despite the relatively muted consumption response, there is an economically important impact of educational spending on households via labor margins.

The remainder of this paper is organized as follows. Section 2 discusses data and sample construction steps for this study. Section 3 describes the identification strategy for estimating the impact of education spending on business spending and household consumption. Section 4 presents the elasticity estimates and explores heterogeneous response by baseline firm growth rates and households' decision to exit self-employment. Section 5 explores the economic wellbeing of households that exit self-employment. Section 6 concludes.

\section{Data and Stylized Facts}

I use de-identified financial accounts data provided by a large U.S. financial institution to construct a panel dataset of self-employed households with children. The final dataset provides a granular view of the business and personal checking account transactions of the business owners and their family members, along with some basic demographic information about the businesses and households. Section 2.1 describes the data construction and the sample selection steps. Section 2.2 discusses how I measure education spending and business performance.

\footnotetext{
${ }^{5}$ The perfect consumption smoothing can also be explained by the fact that the federal student loan program does not ration borrowers based on the students' credit worthiness. Therefore, easier access to credit might allow households to smooth consumption. However, student loans did not constitute a significant share of household balance sheet in the sample period that Souleles (2000) examines, and thus it is unlikely to be the main explanation for this result.
} 


\subsection{Data and Sample Construction}

The starting point of the sample construction is a universe of 1.3 million small businesses with active checking accounts at my financial services company with at least $\$ 500$ in outflows and 10 transactions for 3 out of 12 consecutive months between October 2012 and April 2018. From this universe, I identify businesses whose owners also have a personal checking account at my financial services company. I use my financial services company's record of de-identified account linkages to link businesses to their owners, where a link is established when an individual has multiple accounts with my financial services company. This process reduces the sample to roughly 550,000 small businesses where both business and its owner's personal account transactions can be tracked. Given that my sampled business owners bank both business and personal accounts at my financial services company, my dataset likely provides a comprehensive view of their financial activity.

Next, I identify other members in the household using my financial services company's record of personal account linkages. This de-identified record connects all household members who also have an account at my financial services company and assigns a unique household identifier. Once the members are identified, I obtain checking and credit card account information of all family members in the household. This allows me to capture total education spending that a given household incurs regardless of which member in the household makes the payment. I aggregate the account-transaction level data into a quarterly firm-household level data that captures the total cash flows into and out of the household's combined accounts. I also obtain basic firm and household characteristics, such as the industry in which a business operates, state of residence, the age of the business, and the age of each family member.

A critical step is obtaining the age of the dependents. One challenge with this is that my financial services company does not provide any information on minors who are younger than 19 years old, which makes identifying households with children difficult. I address this challenge by applying the following rule: when a 19 year old's account is linked to a household for the first time in the data, I recover the dependent's birth year to calculate her age for all years that a business is in operation. This method allows me to capture households with children younger than 19 years old without obtaining additional information on the minors. I restrict 
the sample to households with the oldest dependents' age between 14 to 25 years, and to those with no more than 5 family members. This leads to a sample of roughly 150,000 self-employed households with children, which serves as the primary sample for analysis.

Table 1 reports the descriptive statistics of household and business characteristics for selfemployed households with children. The top panel reports statistics for all sample and the bottom panel restricts the sample to households with children aged between 15 and 19 years old. The former sample is used for most of the analysis in this paper, and the latter sample is used for estimating the elasticities. Self-employed households in my sample has on average 3 family members and 1 dependent. The average age of the oldest member of the household is 52 years old, and the oldest dependent's age is 21 . Businesses in professional services, other services, and construction industries represent $38 \%$ of all businesses, and $50 \%$ of all businesses operate in California, New York, and Texas. The descriptive statistics for self-employed households with near college-entering dependents look very similar to the overall sample.

\subsection{Measurement}

I use the transaction-level data to construct measures of household and business spending. I construct three main business performance measures: operating expenses, revenues, and exit. To construct operating expenses and revenues, I first calculate the total cash flows out of and into business checking accounts for each firm and quarter. If a business has multiple checking accounts, they are rolled-up to the firm-level. From these totals, I subtract any financial transactions that are unlikely to represent the actual costs or revenues from running a business. These transactions include transfers between accounts, interest, or fee payments. I identify these transactions using my financial services company's categorization of transaction channels (e.g., "Fees" or "Transfers") and confirm its validity using the identity of the counter party in a transaction. I consider the remaining inflows and outflows to be my operating expenses and revenues.

My financial services company provides several categorization variables that tag transactions based on the counter party. I use these variables to categorize operating expenses into finer spending groups: auto maintenance, office supplies/tools, machinery, or utilities. Auto 
maintenance captures spending at automobile services, repair, or body shops. Office supplies capture spending at home improvement or office supply shops, which likely represents variable input costs for operating a business. Machinery expenses include spending on electronic appliances or industrial equipment. Utility expenses include cable, electric, gas, water, sewer, and other utility services. Finally, I infer exit from the closure of a business checking account or an account's inactivity. Accounts with less than 10 transactions and $\$ 500$ in outflows for three consecutive months (i.e., inactive) are automatically dropped from the sample. Thus, if a firm drops out from my sample before the end of the period, I consider the last quarter that a firm was active as the exiting quarter. ${ }^{6}$

Household consumption aggregates any durable and non-durable spending from personal checking and credit card accounts of all members in a household. This consumption measure can be broken out into goods (e.g., groceries, fuel, home improvement, etc), services (e.g., restaurants, medical spending, air fares, etc), uncategorizable bill payments using PayPal or wire transfers, utilities (e.g., phone bills, internet, and cable, etc), rent, housing debt (e.g., HELOC, mortgages) or non-housing debt payments (e.g., auto, personal, and student loans, etc), or credit card payments. For all of the consumption analysis in this paper, I use consumption net of education spending by subtracting any expenses categorized as education spending in order to track changes in non-tuition related household expenditures.

To construct total spending on education, I validate both personal and business account transactions that my financial services company pre-categorized as education spending based on the transaction descriptions by verifying the channels (e.g., wire, $\mathrm{ACH}$, etc) and counter parties of transactions. The final measure captures any payments to post-secondary institutions (tuition, fees, room and board), testing service agencies such as the ETS, transfers to the 529 plans since tuitions are typically paid directly from the 529 accounts, and student loan payments to student loan servicing and lending institutions such as Sallie Mae, Navient, Nelnet, etc. ${ }^{7}$ My measure does not capture room and board expenses if a student lives off-campus, spending

\footnotetext{
${ }^{6}$ I do not artificially impose business expenses and revenues to be 0 in the exiting quarter, but cash flows of exiting firms tend to be very small (median expenses and revenues of less than \$100).

${ }^{7}$ Since my financial services company heavily redacts checking account transaction descriptions to protect anonymity, finer categorization into tuition, fees, room and board is not feasible. Thus, I aggregate spending as a broader "education spending".
} 
on a child's health or dental insurance, and other discretionary financial support that a family provides when a child enters college. It also does not capture any off-the-book borrowing from friends or family, and education spending made using paper checks.

My education spending measure likely underestimates the actual spending that a household incurs when sending kids to college because it captures narrowly defined out-of-pocket education costs associated with tuitions, and because it does not include any payments made in checks even if a payment satisfies my definition of education spending. However, I argue that my measure is nevertheless a useful proxy for capturing the magnitude of financial burden that arises from sending kids to college for two reasons. First, any results using this conservative measure can be interpreted as a lower-bound of the economic impact of education spending. Second, majority of tuition payments occur through wire transfers in the time period I analyze, and thus, it is unlikely that the exclusion of paper checks will alter the narrative of my findings. To verify this, I contacted a mid-sized research university in the Northeast, and the institution shared data on the breakdown of tuition payment types. Table A.1 shows the breakdown of payment types for the fiscal years 2013 and 2018. This table verifies that roughly $80 \%$ of all payments in terms of dollar amounts are made through wire transfers, which assuages the concern that check payments capture a significant fraction of total education spending.

Table 2 reports descriptive statistics of quarterly education spending for self-employed households with children. Panel A and B compare the average education spending incurred by self-employed households with children aged between 15-17 years old (e.g., Near CollegeEntering Sample) to those with 18-19 years old (e.g., College-Entering Sample). Panels C and D compare the statistics for households with children aged between 18-22 years old (e.g., College-Going Sample) to those with 23-25 years old (College Graduating Sample). In each panel, I report unconditional and conditional statistics of education spending. Top panel shows that the average out-of-pocket quarterly spending on education for households with near-college dependents is around $\$ 321$, but it increases by $85 \%$ for households with college-entering age. Average spending on education remains high while a child is enrolled in school, but it decreases to $\$ 356$ when a child becomes graduating age. A detailed breakdown of education spending 
shows that the average 529 drawdowns increase when a child become college-entering age ${ }^{8}$, and families make student loan payments even during a child's college-enrollment period. Note that the positive student outflows for near college-entering households capture the parents paying for their own student debt.

\section{Empirical Strategy and Stylized Facts}

Section 3.1 presents the identification strategy for estimating the elasticity of business and household spending responses to education spending. Section 3.2 presents stylized facts on the self-employed households' education spending and business outcomes over a child's age profile to motivate the labor margin consideration when examining the economic impact of education spending.

\subsection{Identification}

A simple reduced-form model of the economic impact of education spending is:

$$
Y_{h, t}=\alpha+\sum_{t=1}^{4} \gamma_{t} \mathbb{1}(Q=t)+\beta E_{h, t}+\mathbf{X}_{h, t}^{\prime} \Theta+\eta_{h, t}
$$

where I regress the business outcome $Y_{h, t}$ of a self-employed household $h$ in quarter $t$ on total education-related spending $E_{h, t}$ that the same self-employed household incurs, controlling for time trends using quarter dummies $\mathbb{1}(Q=t)$ with $t=1,2,3,4$ and a vector of baseline business and household covariates, $\mathbf{X}_{h, t}$. These covariates include the age of the business and its owner, the number of dependents in a household, employer status of the business, and a vector of business industry and state of residence indicators. The estimated coefficient $\beta$ then captures the average effect of education spending on business performance.

A concern with this specification is that $\beta$ may be subject to selection bias if potential outcomes and education spending are correlated. Let $\left\{Y_{h, t}^{1}, Y_{h, t}^{0}\right\}$ denote potential outcomes$Y_{h, t}^{1}$ is the business outcome that a self-employed household $h$ would obtain after spending on

\footnotetext{
${ }^{8}$ Roughly 4 percent of my sampled households have a 529 account, slightly higher than the national average of 3 percent (Sager, 2012).
} 
a child's college education, and $Y_{h, t}^{0}$ is the outcome that would have prevailed in the absence of a child attending college. $D_{h, t}$ is a binary variable that indicates whether a child attends college, and the observed outcome $-Y_{h, t}=Y_{h, t}^{0}+\left(Y_{h, t}^{1}-Y_{h, t}^{0}\right) D_{h, t}$ - additively captures the causal impact of education spending on potential outcomes, $\left(Y_{h, t}^{1}-Y_{h, t}^{0}\right) D_{h, t} \cdot{ }^{9}$ Since potential outcomes for any one household is not observed, a naive regression 1 that estimates the average difference between households that do or don't spend on education may be subject to selection bias if, for example, high ability self-employed households are more likely than the low ability households to spend more on education. Such ex-ante sorting may lead to over-estimation of $\beta$ because high ability self-employed households have better potential outcomes, $Y_{h, t}^{0}$.

An ideal strategy to address this concern is the one where college spending is not correlated with potential business outcomes, such that the conditional independence assumption holds - i.e., $\left\{Y_{h, t}^{1}, Y_{h, t}^{0}\right\} \Perp D_{h, t} \mid X_{h}$. While it is unlikely to find a setting where households are randomly assigned to send their kids to college, I exploit two institutional features about the U.S. schooling system that provides a setting akin to this ideal experiment. First, I exploit the fact that the typical college entering age in the U.S. is between 18 and 19 years old. Panel A of figure A.1 plots the age distribution of first-year students who enrolled in the 2015-2016 academic year. 18-19 year olds make up over $96 \%$ of the total first-year enrollment while younger individuals make up less than $2 \%$. While there are no laws requiring students to reach a specific age at the timing of college enrollment, this pattern may in part be explained by the U.S. compulsory schooling laws that prevents students from dropping out of school until they reach 16-18. ${ }^{10}$ Therefore, if a student enrolls in a college within a year or two of her high school graduation, she would most likely be 18 or 19 years old. Second, I exploit the fact that the academic calendar runs from early fall. Since the academic billing cycle starts a few months before the beginning of the academic year, this implies that households are billed their first tuition payment between the second and third calendar quarters.

I combine these features and use a child turning 18-19 interacted with quarter-transition dummies as instruments for a sudden increase in the propensity to spend on a child's educa-

\footnotetext{
${ }^{9}$ Since I do not directly observe a child's college enrollment, I proxy for college attendance with college spending.

${ }^{10}$ While the legal dropout age varies by state, the compulsory schooling age is 18 in roughly half of the U.S. states.
} 
tion. Specifically, this strategy compares self-employed households with college-entering aged dependents (18-19) to otherwise similar self-employed households with near college-entering aged dependents (15-17) in each quarter-to-quarter transition cell. ${ }^{11}$ This strategy allows for examining the impact of education spending on business outcomes for several reasons. First, the academic billing cycle and the norm of entering college at age 18-19 are pre-determined institutional features that are orthogonal to business cycles, industry trends, or other factors that may be correlated with firm performance. Thus, it is unlikely that my instruments are correlated with potential business outcomes. Second, the instruments have clear and monotonic impact on education spending. Households either increase or do not spend on education when a child becomes college-going age, but it is unlikely that they would reduce spending on education. Thus, by comparing similar households with dependents that are close in age, but with one group of households having exogenously higher propensity to spend on education due to U.S. schooling norms, I can estimate the effect of education spending on business performance that is not confounded by selection bias.

Despite the fact that the conditional independence assumption $\left\{Y_{h, t}^{1}, Y_{h, t}^{0}\right\} \Perp D_{h, t} \mid X_{h}$ likely holds in this setting, households may be able to predict the cost and timing of their dependents' college enrollment well in advance. Given that sending kids to college is a major financial event for many households, it is plausible that self-employed parents prepare for their child's college education in various ways through saving, adjusting labor supply, or reducing consumption in advance. While some degree of ex-ante college planning is expected, whether households can perfectly plan for this highly anticipated negative income shock is unclear given that a child's college admission decisions and expenditures are not known until a few months before a child enters college when the acceptance letters are sent out and the financial aid packages are revealed. And even if households have perfect foresight, the extent to which they are able to smooth this financial shock is ultimately an empirical question. If households do not respond to short-term transitory shocks (LC-PIH) or can perfectly plan for college costs, this will bias against finding an impact. ${ }^{12}$ On the other hand, if households cannot perfectly plan for college

\footnotetext{
${ }^{11}$ This strategy is akin to Angrist and Krueger (1991) who used quarter-of-birth instruments to estimate the returns to schooling.

${ }^{12}$ Pre-planning can bias my estimates upward if a self-employed household grows its business more aggressively prior to a child turning college-entering age. However, figure 2 shows that there is no systematic business
} 
costs, a sudden increase in the propensity to spend on education can lead to meaningful impact on households' economic well-being.

Figure 4 provides a graphical motivation of this identification strategy. This figure plots the average education spending against calendar time for self-employed households with collegeentering dependents - i.e., treated households with 18-19 year olds- and that for otherwise similar households with near college-entering dependents - i.e., control households with 15-17 year olds. Three features are notable. First, treated households spend more on education relative to control households at any given time. Second, treated households have large spending spikes between the second and third quarters, consistent with the fact that treated households experience a large education spending burden just before the fall enrollment due to academic billing cycle. Lastly, control households have relatively flat education spending spending path over time with small spending spikes around fourth quarter each year, which may reflect the costs associated with college applications. Overall, the figure highlights that a child becoming college-entering age coupled with academic billing calendar can generate a strong first-stage response.

I apply this logic to the following Two-Stage Least Squares (2SLS) model:

$$
\begin{aligned}
& E_{h, t}=\alpha_{h}+\sum_{t=1}^{4} \gamma_{t}^{F S} \mathbb{1}(Q=t)+\sum_{t=1}^{4} \beta_{t} \mathbb{1}(Q=t) \times \mathbb{1}\left(A g e_{h, t} \in 18,19\right)+\mathbf{X}_{h, t}^{\prime} \Theta^{F S}+\eta_{h, t} \\
& Y_{h, t}=\alpha_{h}+\sum_{t=1}^{4} \gamma_{t}^{S S} \mathbb{1}(Q=t)+\rho \widehat{E_{h, t}}+\mathbf{X}_{h, t}^{\prime} \Theta^{S S}+\varepsilon_{h, t}
\end{aligned}
$$

where the first stage and second stage (reduced form) outcomes are logarithmic of total education spending and business performance measure of self-employed household $h$, respectively. $\mathbb{1}(Q=t)$ and $\mathbf{X}_{h, t}$ are the same as in specification 1 , and $\mathbb{1}(Q=t) \times \mathbb{1}\left(A g e_{h, t} \in 18,19\right)$ are the instruments that interact quarter dummies with a binary indicator for whether the oldest child in a household $h$ is 18 or 19 years old. I include household fixed-effects, $\alpha_{h}$, to control for the time-invariant differences across households. This 2SLS-IV model allows me to interpret the coefficient $\rho$ as the average impact of education spending on business performance that is expansion before a child turns college-entering age. Thus, it is unlikely that anticipation leads to an upward bias. 
not confounded by selection bias. Standard errors are clustered at the household-level.

I apply two sample restrictions for these regressions. First, as mentioned above, the regression sample restricts self-employed households to those with college-entering aged dependents and with near college-entering aged dependents. This restriction is applied because it allows for apples-to-apples comparison across households. The identifying assumption is that households with younger dependents that are close in age to college-entering dependents serve as a valid control group as they likely undergo similar business and household life-cycle dynamics as treated households, conditional on covariates. Table A.2 reports the average characteristics of the self-employed households with near-college entering dependents (15-17 year olds) and those with college-entering dependents (18-19 year olds). Consistent with the identifying assumption, this table shows that the two groups are very similar in terms of their family and business characteristics, with the main noticeable difference being the age of the dependents and the head of the household being older for the latter group. Second, I exclude any selfemployed households that operated a business for less than 1 year. This restriction is made because including new entrants may lead to selection bias if a child being college-age is correlated with the parents' decision to become self-employed. Therefore, I only consider self-employed households that have operated a business for at least one year in my regression analysis.

Several features of the 2SLS equation 2 are noteworthy. First, using logarithmic of outcome variables allows me to interpret $\rho$ as the elasticity of household outcome $Y_{h, t}$ with respect to the predicted education spending $\widehat{E_{h, t}}$. It also has the additional benefit of attenuating the influence of outliers. ${ }^{13}$ Second, using firms fixed-effects allows me to interpret $\beta_{t}$ as the change in education spending between quarter-to-quarter transitions. For example, $\beta_{3}$ captures the household response between second to third quarter rather than the average effect of the third quarter. Thus, flexibly fitting quarter-to-quarter transitions reveal differential magnitude of education spending induced by the academic billing cycle. Finally, the excluded instruments from the second stage equation 3 are the four quarter-transition dummies interacted with an indicator that equals 1 if a child is college-entry age. Since quarter-transition dummies are also included in this equation, the effect of education spending is identified by variation in spending across

\footnotetext{
${ }^{13}$ Measuring outcomes in logarithmic of scaled measure is a conventional approach used to control for baseline differences in the outcomes across units of observations. See, for example, Autor et al. (2013).
} 
similar households with varying children's age within each quarter-transition cell. In other words, the estimated effect picks up the differential business response for households with 1819 year olds relative to other households with younger dependents (i.e., $15 \leq$ age $\leq 17$ ) within each $t$. In summary, the proposed 2SLS specification considers a child being college-entering age as the intention-to-treat instrument based on the institutional feature that the typical college entering age in the U.S. is between 18 and 19.

\subsection{Stylized Facts}

I provide several novel stylized facts on how education spending and business outcomes evolve over a child's age profile. Throughout the rest of the paper, only the age of the oldest dependent is considered when a household has multiple dependents. I focus on the age of the oldest dependents because their college entrance likely constitutes more salient life and financial events for families compared to sending younger dependents to college. Moreover, using the age of the younger child may bias the results upward if households with multiple college-going children have higher education spending.

Figure 1 provides a visual presentation of how self-employed households' education spending evolves over a child's age profile. Panel A plots conditional (dashed) and unconditional (solid) average quarterly spending on education for all self-employed households with children. The shaded gray area represents the age profile when a dependent is most likely to be enrolled in college. The figure shows a striking pattern of a sudden and large increase in spending around dependents' 18 year-old age mark and persistence in high levels of spending. The conditional averages are higher across all ages cells compared to unconditional averages, and this gap widens particularly during the dependent's college-enrollment period.

Panel B plots the education spending as a share of household's non-durable consumption, where non-durable consumption includes household spending on non-durable goods, services, and utilities net of education spending. Both panels A and B show that education spendingeither in levels or as a share of consumption - rises steeply when a child becomes 18 , continues to rise, and reaches its peak when a child becomes 21 years old. This is consistent with the feature cost of college attendance tends to rise as students persist through college. The conditional 
average of education spending represents around $20 \%$ of non-durable consumption at its peak, implying that out-of-pocket spending on education is economically meaningful.

To motivate the self-employed households' labor margin consideration for examining the economic impact of education spending, I document how business outcomes evolve over a child's age profile. If a child's college-going behavior does not affect how self-employed parents operate their businesses or their decision to switch jobs, there would be no detectible pattern of business outcomes over a child's age profile. Figure 2 plots the average business expenses, revenues, investments, and exit rates over a child's age profile. This figure shows that business operating expenses, revenue, and investment spending decline monotonically, whereas exit rates steeply rise when a child becomes college-going age.

To better account for differences in household and business characteristics in examining the relationship between business outcomes over a child's age profile, I run the following regressions:

$$
Y_{h, t}=\alpha+\beta_{a} \sum_{a=18}^{25} \mathbb{1}(\text { Child's Age }=a)+\mathbf{X}_{h, t}^{\prime} \Theta+\eta_{h, t}
$$

where $Y_{h, t}$ denotes quarterly business outcomes scaled by the household $(h)$-specific baseline average of the outcome, where the baseline period is before a child becomes 18 years old. ${ }^{14}$ The household-specific scaling factor allows for comparison across different business size. $\mathbf{X}_{h, t}$ includes household and business characteristics, such as business industries, state of residence, and the age of the oldest member in a household. Therefore, the estimate vector $\beta_{a}$ captures the average effect of self-employed households having $a$-year old dependents, and it's identified by both cross-sectional and within variations of households by comparing business outcomes when a child is $a$ years old relative to when a child is younger than 18 .

Figure 3 plots the estimated $\beta_{a}$ against the dependent's age profile. The estimates are also reported in table A.3. Similar to figure 2, self-employed households' operating expenses, revenues, and investment spending declines, whereas the probability of exit rises when a child becomes college-entering age relative to when a child is younger. Specifically, self-employed households spend 1 cent less in operating expense per dollar of baseline average when a child

\footnotetext{
${ }^{14}$ For households that do not have pre- (i.e., child is always older than 18) or post-period (i.e., child is always younger than 18 in the sample), I use the household-specific sample mean of the outcome as a scaling factor.
} 
is 18 years old, and this number declines to roughly 4 cents per baseline dollar when a child is 25 years old. Given that the baseline mean of expense is around $\$ 66,000$, these estimates correspond to roughly $\$ 6,600$ to $\$ 26,400$ decline in quarterly expenses in levels, which is as large as a full quartile of the distribution of business expenses. Households also earn 1 cent less per dollar of baseline average and exit probabilities rise by $0.1-0.5 \%$ when a child is college-entering age relative to pre-18 averages.

Overall, these stylized facts provide descriptive evidence that self-employed households' business performance is tightly linked to their dependent's age profile. Over the same age profile during which households incur large education spending for sending kids to college, business performance declines and exit rates from self-employment rises. One interpretation of this evidence is that self-employed households downsize their business production either willingly by choice or unwillingly due to education spending burden that arises from sending kids to college. I examine this labor margin response of the self-employed households in the remaining sections.

\section{Main Results}

This section presents the estimation results. Sections 4.1 and 4.2 presents the business spending and household consumption elasticity estimates from the 2SLS model described in section 3.1. Section 4.3 explores heterogenous business and consumption effects by baseline firm growth rates to test whether self-employed households plan for a child's education spending by adjusting firm growth rates prior to a child a child entering college. 4.4 highlights the link between career choice and consumption more directly by comparing business spending and consumption patterns of households that continue to run business to those that exit from selfemployment.

\subsection{The Effect of Education Spending on Business Outcomes}

Table 3 reports the estimates of the 2SLS-IV model described in section 3. Column 1 reports the control mean of each outcome in levels. Columns 2 to 5 report $\beta_{t}$ from the first stage and 
reduced form equations that regress log transformed education spending (endogenous variable) and business outcomes (reduced form outcome) on a set of quarter transition dummies interacted with a college-entry indicator that equals 1 if a child is 18 or 19 years old. Column 6 reports the 2SLS estimate $\rho$ from the second stage equation 3. All regressions control for the age of the business and its owner, employer status of the business, industries and state of residence, number of dependents in a household, and employer status of the business. Standard errors are clustered at the household-level.

The first stage estimate in column 2 shows that education spending of self-employed households with college-entering dependents increases by $24 \log$ points compared to other similar households with younger dependents in the same first to second quarter transition cell. Columns 3 and 4 show that the estimated effects increase to 41 and $33 \log$ points in the second to third and the third to fourth quarter transition cells, respectively. The increase in spending in the second half of the year reflects the norm that post-secondary institutions bill incoming students just before the semester starts. Converting the first stage effect into an implied dollar magnitude, I find that a $41 \log$ point increase translate into $\$ 162$, or $46 \% \approx \frac{\$ 162}{\$ 354}$ of the sample mean. ${ }^{15}$ Therefore, the the first stage impact is economically meaningful.

The reduced form estimates show that households with college-entering dependents cut back on business expenses, generate lower revenues, and have higher probability of exit. Columns 2 to 5 report that business operating expenses and revenues decline by 2 to $4 \log$ points for the treated relative to control. These estimates correspond to reductions of $\$ 2,732$ in expenses and $\$ 2,598$ in revenues, or reductions of $15-20 \%$ of median expense and revenue, respectively. Since the control mean of log transformed expenses (revenues) is $-0.10(-0.14)$, the treatment effect in a given quarter is one fifth in size relative to the sample means. The probability of exit increases by 0.2 percentage points for treated relative to control group in each quarter, or roughly $22 \%$ of the sample mean. Figure 5 illustrates these results graphically. This figure plots $\beta_{t}$ from the first stage and reduced form regressions for each quarter-transition cell.

The detailed breakdown of operating expenses explores heterogeneous intratemporal substi-

\footnotetext{
${ }^{15}$ Note that the estimated effect $\beta_{t}$ picks up the average difference in the log transformed outcome between treated and control. Thus, treatment effects in log points can be transformed into the same unit as the outcome by raising $e$ to the $\beta_{t}$ power and subtracting 1 (i.e., $e^{\beta_{t}}-1$ ). To obtain the implied dollar terms, I multiply this number with the sample average of each outcome.
} 
tution margins. Specifically, the magnitude of the treatment effect indicates whether businesses cut expenses equally across various spending categories or whether there are margins they cut by more relative to others. For households with college-entering dependents, business spending on office supplies/tools and machineries decline by roughly 6 log points. However, there is no differential spending response on utilities for treated relative to control households, implying that businesses differentially cut back on margins that are easier to adjust. ${ }^{16}$

Column 6 reports the 2SLS elasticity of business spending to education spending. The results indicate that an increase in instrumented spending on education by a log point leads to a reduction in business expenses and revenues by $7-8 \log$ points. Since one standard deviation of instrumented education spending is 0.13 , these estimates imply that a one standard deviation increase in the instrumented education spending leads to a one percentage point $(.13 \times-.08 \approx$ -.0104) decline in business expenses and revenues per quarter, or roughly 4 percentage points annually. The extensive margin estimate for exit probability is 0.3 percentage points, which is about as large as $33 \%$ of the sample mean. Figure 6 illustrates these results graphically. Overall, education spending induced by a child's college-entry age generates economically meaningful intensive and extensive margin responses for small businesses.

\subsection{The Effect of Education Spending on Household Consumption}

Table 4 reports the elasticity of consumption to changes in education spending. To capture how non-education related consumption responds to increased education spending, my consumption measure aggregates spending incurred by each member of a household through their personal checking and/or credit card accounts net of education spending. I estimates the elasticity using this net consumption measure as well as several sub-categories of consumption, such as spending on non-durable goods, durable goods, services, utility, and mortgage. The variable description table A.6 reports details on the spending types that each sub-category captures. Note that the total consumption measure includes more categories than those reported in table

\footnotetext{
${ }^{16}$ In my sample, only 15 percent of small businesses in my sample are employer firms that have regular payroll expenses. Thus, I use the employer status of the firm as a baseline covariate instead of examining change in payroll expense as an outcome.
} 


\section{$4 .{ }^{17}$}

Columns 2 to 5 show that consumption net of education expenditure increases by 2 to $4 \log$ points in a given quarter for the self-employed households with college-entering dependents relative to those with younger dependents. Examining the detailed consumption sub-categories, I find that spending on non-durables - particularly on groceries-and mortgage payments decline by 4 to $8 \log$ points for treated relative to the control group. On the other hand, spending on durable goods and services - particularly medical and restaurant expenses - rise by 2 and 8 $\log$ points, respectively, for treated relative to the control households. I find that there is no differential spending patterns for treated relative to control households on utilities. Column 6 reports that the elasticity of consumption to education spending is 8.5.

Figures 7 and 8 illustrates these results graphically. In both figures, panel A reports reduced form estimates that regress household consumption outcomes on a set of quarter transition dummies interacted with treatment status that equals 1 if a child is 18 or 19 years old, and panel B reports the 2SLS-IV estimates. These figures show that while the estimated effect on net consumption is positive in every quarter-transition cells, there is substantial heterogeneity in the spending response by detailed categories.

There are several ways to interpret the consumption results. Households may be cutting back some margins in order to increase the discretionary spending associated with a child entering college that is not directly captured by tuition costs, or self-employed parents may change spending patterns due to adjustments in consumption-leisure tradeoff after sending kids to school. For example, the increase in medical spending may capture the costs associated with increasing doctor's visits in order to provide a proof of physical examination and vaccine receipts, as mandated by many colleges in the U.S. It is also reasonable to interpret this as selfemployed parents increasing doctor's visits because they have more time in hand. Similarly, the increased restaurant spending and decreased spending on groceries may reflect reduction in home production due to a child leaving home or parents dining out more. While both of these hypotheses likely contribute to the changes in consumption patterns, the next section presents results that show that the former hypothesis - households adjust consumption in order to in-

\footnotetext{
${ }^{17}$ For example, other categories include credit card payments, non-housing debt payments, HELOC, taxes, and other miscellaneous online payments.
} 
vest in a child's human capital - is likely to be the primary driver of the changes in household consumption.

\subsection{Strategic Planning}

Do self-employed households plan for a child's college entry by adjusting their firm size prior to a child entering college? If households strategically downsize the firm before a child turns 18 in order to smooth college expenses, such strategic planning will reveal that businesses with lower baseline growth rates fare better with college expenses. On the other hand, it is plausible that self-employed households with high baseline firm growth rates smooth education spending shocks better relative to households that operate low growth firms. To explore these hypotheses, I calculate firm-specific year-over-year average sales growth before a child turns 18 among selfemployed households with college-entering dependents. I then group firms into quartile bins, where bin 1 includes firms with the lowest pre-18 average growth rates and bin 4 the highest. For each growth bin, I estimate equation 4 to examine how $\beta_{a}$ evolves over a child's college enrollment spell.

Figure 9 plots $\beta_{a}$ against a child's age for each subgroup of firms with varying baseline growth propensities. The estimated coefficients capture the effect of self-employed households having an $a$-year old dependent on business expenses and revenues. This figure shows that the lowest growth firms show the largest business response when a child turns 18 while the highest growth firms show the smallest response. However, business response in all growth groups converge over a child's enrollment spell- expenses and revenues decline when a child enters college, but they bounce back once a child reaches graduation age for all growth bins. This spending pattern is consistent with self-employed households reducing spending during a child's college enrollment. Appendix figure A.2 reports the results for spending on machinery and exit probabilities, and show that firms in the lowest growth bin cut back on machinery the most and are most likely to exit when a child enters college.

Figure 10 explores household consumption response net of education spending by baseline growth bins. For all growth bins, net consumption increases during a child's college enrollment spell and declines once a child reaches 21 . This spending pattern is consistent with households 
temporarily increasing non-tuition related discretionary spending associated with sending kids to college rather than self-employed parents permanently changing their consumption behavior due to a child leaving home. If the adjustment in consumption-leisure associated with a child leaving home is the primary driver behind the changes in consumption patterns, these patterns would remain the same after a child reaches graduation age. Consistent with figure 9, the lowest growth bin increases net consumption the least while they cut back on non-durable goods spending the most. Appendix figure A.3 reports the results for spending on durable goods and services.

Overall, these figures highlight several takeaways. First, it is unlikely that self-employed households can perfectly plan for a child's college spending by strategically growing or downsizing the firm in advance because businesses in all growth bins cut back expenses when a child enters college. Second, there is substantial heterogeneity in the magnitude and timing of business effects when a child enters college by baseline growth propensities. High growth firms tend to cut back on business spending less and later relative to low growth firms, and they are more likely to increase net consumption. Lastly, there is less heterogeneity in household consumption response relative to business effects across growth bins. This implies that examining household consumption may not be sufficient to understand the overall welfare implication of self-employed households. Even if self-employed households of all business growth types increase net consumption, there is substantial variation in the degree to which education spending affects labor decisions.

\subsection{The Link between Career Choice and Consumption}

So far, the results indicate that while education spending leads to increase in non-education related household consumption, it induces self-employed households to downsize their business production and exit from self-employment. One interpretation of this pattern is that selfemployed households are adjusting their labor margins in order to meet the financial obligation of investing in a child's human capital. This section explores this link between career choice and consumption more directly by comparing business and consumption response of households that continue to be self-employed relative to those that ultimately exit from self- 
employment. In order to track the outcome paths by subgroups, I return to employing the reduced-form model 4 , which estimates the treatment effect at each age $a \geq 18$ relative to the pre-18 baseline average.

Table 5 reports education and business spending responses for self-employed households that continue to remain in self-employment ("stay") to those that switch their career to wageearning employment ("exit"). To be specific, the "exit" sample contains self-employed households that eventually exit at some point during my sample period (2012Q4 to 2018Q2), whereas the "stay" sample contain households that never exit. Therefore, the outcomes for the "exit" sample reflect the spending dynamics before the owners exit self-employment. Comparing columns 2 through 4 to 6 through 8 , I find that the business response is larger for exit relative to stayer sample at each of dependent's age profile $a$, whereas columns 1 and 5 show that stayer households spend more on education than those that exit. This result not surprising given that businesses that ultimately exit would be expected to downsize their production before they exit. However, this result is not a simple mechanical artifact purely driven by exiting households because the stayer households also downsize their business production. Figure A. 4 provides a visual guidance of these results.

Table 6 compares the consumption response for households that stay and exit. As before, the consumption outcomes for the "exit" sample reflect the consumption path before the business owner exits self-employment. Comparing columns 1 to 5, I find that the increase in total consumption net of education expenditure is larger for households that remain in selfemployment relative to those that eventually exit. Exiting households cut back on groceries by more than those that remain in self-employment, whereas the increase in restaurant and medical spending is mainly driven by households that remain in self-employment. Overall, both exiting and stayer households do a good job at smoothing consumption, but households that remain in self-employment appear to smooth consumption better relative to those that exit eventually. Figure A.5 provides a visual guidance of these results.

To recap, the main goal of this section is to explore whether self-employed households adjust their labor margins by downsizing business production or switching careers in order to smooth consumption. I find that households that remain in self-employment increase both ed- 
ucation spending and non-education related consumption more than those that eventually exit from self-employment, even though they scale back on business production less. One interpretation of this result is that exiting households are being forced to return to wage-earning employment in order to smooth consumption from transitory education spending shocks. Otherwise - if exit decisions are voluntary and unrelated to a child's education spending - we would not expect to see any heterogeneous response in household consumption by the self-employed parents' career choice decisions.

To better understand whether exit rates are linked to the child's college-going behavior, figure A.6 presents the share of households that exit from self-employment over a child's age profile (top panel) and the cumulative exit rates over a child's age profile conditional on exiting (bottom panel). Two features are notable. First, the share of businesses that exit increases as the child gets older. Second, conditional on exiting, most households exit when the child is likely to be enrolled in college. The cumulative exit rates indicate that less than $20 \%$ of firms have exited when the dependent is younger than 18 years old, but more than $80 \%$ of the firms have exited by the time the dependent reaches the graduating age. Therefore, the descriptive evidence is consistent with the hypothesis that a child's college-going behavior is linked to the self-employed households' career choice decisions.

These findings raise the question of whether the economic well-being of households that are induced to exit from self-employment worsen after exiting. These households can experience economic difficulty if they're unable to transition to wage-earning jobs quickly, or they may actually be better off if they can quickly earn stable income. The next section addresses these questions by tracking the financial accounts of households after they exit self-employment.

\section{Post-Exit Response}

This section explores the household consumption and income paths after self-employed households exit from self-employment. Subsection 5.1 provides reduced form evidence of how consumption and income paths evolve after exiting. Subsection 5.2 investigates variation in these effects by the timing of exit. 


\subsection{Consumption and Income Paths}

I track consumption and income paths of households that exit from self-employment by estimating the following equation:

$$
Y_{h, t}=\sum_{s=1}^{8} \beta_{s} \mathbb{1}\left(\text { Exit }_{t+s}\right)+\mathbf{X}_{h, t}^{\prime} \Theta+\eta_{h, t}
$$

where $Y_{h, t}$ denotes quarterly consumption or income scaled by its pre-exit average for selfemployed household, $h$. The household-specific scaling factor allows for comparison across different households with varying levels of pre-exit non-business income. $\mathbf{X}_{h, t}$ includes the same household and business covariates used in the previous section. The estimate vector $\beta_{a}$ captures the average effect of post-exit response on the outcome $s$ periods after exiting from self-employment. Standard errors are clustered at the household level.

Table 7 reports the consumption and income paths after a household exits self-employment. I track the results for 2 years (or 8 quarters) after they exit from self-employment. Column 1 shows that households that exit from self-employment immediately increase consumption relative to the pre-exit mean. In the first quarter after exiting, households increase consumption by 11 cents per dollar of pre-exit consumption mean, and this number increases to 19 cents 2 years after exiting. Column 2 shows that households experience more than $100 \%$ increase in the labor income as soon as they exit from self-employment as they earn \$1.12 per dollar of pre-exit mean of labor income, and this number increases to $\$ 2.52$ after 2 years. Column 3 shows that households also earn side income by participating in the gig economy after they exit, and continue to earn more gig income in the periods following exit even though labor income also goes up. It is worth noting that the share of households that receive unemployment benefits does not change after exiting self-employment. This result is expected given that non-employer small business owners are not typically eligible to collect unemployment benefits.

Overall, I find that households that exit from self-employment do a good job at smoothing consumption even after exiting and that they transition to wage-earning jobs quickly. A natural interpretation of these results is that the self-employed parents become wage-earners in order to smooth consumption, or to meet the financial obligations of investing in a child's human 
capital. Under this interpretation, high education costs may have implications for welfare even if households do a good job at smoothing consumption because households may incur significant loss of non-pecuniary benefits of small business ownership (Hurst and Pugsley, 2011) or derive disutility from switching careers. Moreover, the fact that the business owners have limited downside insurance may play a role in self-employed owners quickly transitioning to wage-earning jobs or entering the gig economy. However, whether this transition is optimal is unclear given that the limited downside insurance may force people to take worse jobs than they would otherwise take if they are eligible for unemployment benefits and have the flexibility to search for jobs longer.

\subsection{Heterogeneity by Exit Timing}

One implication of the result that households can quickly transition to wage-earning jobs is that they may have timed their exit from self-employment. In particular, it is plausible that households that exit before a child reaches college-entering age may be forward-looking households that exited preemptively in order to smooth consumption, whereas those that exit after a child becomes 18 may be those that are induced to exit due to high spending burden. Thus, to the extent that exit timing captures financial constraint that a household experiences, we would expect to see that households that are forced to exit earn more labor and gig economy incomes to smooth the financial shock.

Figure 11 investigates post-exit consumption and income responses for households that exit before a child becomes 18 (blue) and those that exit after (red). Consistent with the results in table 7, I find that both consumption and income increase immediately after households exit self-employment. However, the consumption response is lower while the labor income and gig-economy income responses are higher for households that exit after a child is 18 relative to households that exit before a child is 18 . This result is consistent with the hypothesis that exit timing may capture the financial burden that households may experience from sending a child to college. 


\section{Concluding Remarks}

This paper studies the economic implications of education spending for self-employed households. When a child goes to college, households downsize business production and exit selfemployment. While they do a good job at smoothing consumption, they change the composition of spending by reducing debt payments and groceries and increasing medical and restaurant spending. This result is consistent with households adjusting intratemporal consumption margins to smooth costs associated with sending kids to college. Despite the fact that high college costs induce households to exit self-employment, this does not lead to a permanent decline in consumption even after they exit because they can quickly transition to wage-earning employment and make side income from entering the gig economy. These results suggest that when a child enters college, consumption smoothing may come at the expense non-pecuniary benefits of small business ownership.

This paper provides several policy implications. First, I find that education-related financial burden extends beyond the individuals who attend college and has broader impact on the families that share the education spending burden. Policy-makers must take the financial health of families into account to better assess the implications of rising education costs. Second, this paper finds that the ability to participate in the gig economy plays a crucial role for household consumption smoothing. Thus, policies promoting alternative labor market opportunities can help families meet the financial obligations of investing in a child's human capital. Lastly, policies aimed at fostering entrepreneurial activity must consider the family structure of the business owner. To the extent that paying for college constitutes a financial hindrance for operating a business, policies that provide subsidies or tax breaks when business owners have to pay for a child's education may revitalize business dynamism in the U.S.

There are many promising directions for future research. One is examining the householdlevel response beyond student outcomes to study the broader economic implications of rising education costs. Another direction is to examine how wage-earning households adjust their labor supply in order to smooth consumption when a child attends college. Finally, there is a dearth of credible evidence on the financial health of self-employed households. To the extent that these households face different income risks relative to typical wage-earning households, 
studying this population can broaden our understanding of their financial behavior and decision making. 


\section{References}

Altonji, Joseph G., Anthony A. Smith JR., and Ivan Vidangos, "Modeling Earnings Dynamics," Econometrica, 2013, 81 (4), 1395-1454.

Ambrose, Brent W., Lawrence Cordell, and Shuwei Ma, "The Impact of Student Loan Debt on Small Business Formation,” Working paper, 2015.

Angrist, Josh D. and Alan B. Krueger, "Does Compulsory Schooling Attendance Affect Schooling and Earnings?," Quarterly Journal of Economics, 1991, 106 (4), 979-1014.

Autor, David H., David Dorn, and Gordon H. Hanson, “The China Syndrome: Local Labor Market Effects of Import Competition in the United States," American Economic Review, 2013, 103 (6), 2121-2168.

Bachas, Natalie, "Pricing, Selection, and Welfare in the Student Loan Market: Evidence from Borrower Repayment Decisions,” Working paper, 2017.

Baker, Scott, "Debt and the Response to Household Income Shocks: Validation and Application of Linked Financial Account Data," Journal of Political Economy, 2018, 126 (4), 1504-1557.

Baugh, Brian, Itzhak Ben-David, Hoonsuk Park, and Jonathan A. Parker, "Asymmetric Consumption Response of Households to Positive and Negative Anticipated Cash Flows," Working paper, 2018.

Baum, Sandy, "Does Increasing Reliance on Student Debt Explain Declines in Entrepreneurial Activity?," Research Report. Washington: Urban Institute, 2015.

Belley, Philippe and Lance J. Lochner, "The Changing Role of Family Income and Ability in Determining Educational Achievement," Journal of Human Capital, 2007, 1 (1), 37-89.

Blundell, Richard, Luigi Pistaferri, and Ian Preston, "Consumption Inequality and Partial Insurance," American Economic Review, 2008, 98 (5), 1887-1921.

$\ldots, \ldots$, and Itay Saporta-Eksten, "Consumption Inequality and Family Labor Supply," American Economic Review, 2016, 106 (2).

Broda, Christian and Jonathan A. Parker, "The Economic Stimulus Payments of 2008 and the Aggregate Demand for Consumption," Journal of Monetary Economics, 2014, 68.

Caldwell, Sydnee, Scott Nelson, and Daniel Waldinger, "Tax Refund Expectations and Financial Behavior," working paper, 2018. 
Carneiro, Pedro and James Heckman, "The Evidence on Credit Constraints in Post-Secondary Schooling," The Economic Journal, October 2002, 112, 989-1018.

Cooper, Daniel and Maria José Luengo-Prado, "House Price Growth when Children are Teenagers: A Path to Higher Earnings?," Journal of Urban Economics, 2015, 86, 54-72.

Eagan, Kevin, Ellen B. Stolzenberg, Joseph J. Ramirez, Melissa C. Aragon, Maria R. Suchard, and Cecilia Rios-Aguilar, "The American Freshman: Fifty-Year Trends, 1966-2015,” Technical Report, Los Angeles: Higher Education Research Institute, UCLA 2016.

Evans, David S. and Boyan Jovanovic, "An Estimated Model of Entrepreneurial Choice under Liquidity Constraints," Journal of Political Economy, 1989, 97 (4), 808-827.

Farrell, Diana, Fiona Greig, and Erica Deadman, "Student Loan Payments: Evidence from 4 Million Families," JP Morgan Chase Institute, 2019.

Fos, Vyacheslav, Andres Liberman, and Constantine Yannelis, "Debt and Human Capital: Evidence from Student Loans," Working paper, 2017.

FRB, Federal Reserve Board, "Report on the Economic Well-Being of U.S. Households in 2017 - May 2018," Survey of Household Economics and Decision Making (SHED) May 2019.

Ganong, Peter and Pascal Noel, "Consumer Spending During Unemployment: Positive and Normative Implications," forthcoming in American Economic Review, 2018.

Gicheva, Dora, "In Debt and Alone? The Causal Link between Student Loans and Marriage," working paper, 2013.

Goodman, Sarena, Adam Isen, and Constantine Yannelis, "A Day Late and a Dollar Short: Liquidity and Household Formation amond Student Borrowers," working paper, 2018.

Gross, David B. and Nicholas S. Souleles, "Do Liquidity Constraints and Interest Rates Matter for Consumer Behavior? Evidence from Credit Card Data," Quarterly Journal of Economics, 2002, 117 (1), 149-185.

Hall, Robert and Frederic Mishkin, "The Sensitivity of Consumption to Transitory Income: Estimates from Panel Data on Households," Econometrica, 1982, 50 (2), 461-81.

Headd, Brian, "Small Business Facts: Student Debt Among Young Entrepreneurs," SBA Office of Advocacy November 2014.

Herbst, Daniel, "Liquidity and Insurance in Student Loan Contracts: The Effects of Income-Driven Repayment on Borrower Outcomes," Working paper, 2019. 
Holtz-Eakin, Douglas, David Joulfaian, and Harvey S. Rosen, "Sticking it Out: Entrepreneurial Survival and Liquidity Constraints," Journal of Political Economy, 1994, 102 (1), 53-75.

Hombert, Johan, Antoinette Schoar, David Sraer, and David Thesmar, "Can Unemployment Insurance Spur Entrepreneurial Activity? Evidence from France," working paper, 2016.

Hurst, Erik and Benjamin Wild Pugsley, "What Do Small Businesses Do?," Brookings Papers on Economic Activity, 2011, (2), 73-142.

Johnson, David S., Jonathan A. Parker, and Nicholas Souleles, "Household Expenditure and the Income Tax Rebates of 2001," American Economic Review, 2006, 96 (5), 1589-1610.

Keane, Michael P. and Kenneth I. Wolpin, "The Effect of Parental Transfers and Borrowing Constraints on Educational Attainment," International Economic Review, 2001, 42 (4), 1051-1103.

Krishnan, Karthik and Pinshuo Wang, "The Cost of Financing Education: Can Student Debt Hinder Entrepreneurship?," Management Science, 2018, Forthcoming.

Lochner, Lance J. and Alexander Monge-Naranjo, "The Nature of Credit Constraints and Human Capital," American Economic Review, 2011, 101 (6), 2487-2529.

Lovenheim, Michael F., "The Effect of Liquid Housing Wealth on College Enrollment," Journal of Labor Economics, 2011, 29 (4), 741-771.

_ and C. Lockwood Reynolds, "The Effect of Housing Wealth on College Choice: Evidence from the Housing Boom," Journal of Human Resources, 2013, 48 (1), 1-35.

Maggio, Marco Di, Ankit Kalda, and Vincent Yao, "Second Chance: Life without Student Debt," NBEr Working Paper 25810, 2019.

Mueller, Holger M. and Constantine Yannelis, "Reducing Barriers to Enrollment in Federal Student Loan Repayment Plans: Evidence from the Navient Field Experiment,” Working paper, 2019.

Parker, Jonathan A., Nicholas Souleles, David S. Johnson, and Robert McClelland, "Consumer Spending and the Economic Stimulus Payments of 2008," American Economic Review, 2013, 103 (6), 2530-53.

Rothstein, Jesse and Cecilia Elena Rouse, "Constrained after college: Student loans and early-career occupational choices," Journal of Public Economics, February 2011, 95 (1-2), 149-163.

Sager, Michelle, "Higher Education: A Small Percentage of Families Save in 529 Plans," Technical Report GAO-13-64, General Accountability Office December 2012.

Souleles, Nicholas, "College Tuition and Household Savings and Consumption," Journal of Public Economics, 2000, 77, 185-207. 
Sun, Stephen Teng and Constantine Yannelis, "Credit Constraints and Demand for Higher Education: Evidence from Financial Deregulation," Review of Economics and Statistics, March 2016, 98 (1), $12-24$ 


\section{Figure 1: Average Spending on Education over a Child's Age Profile}

Notes: This figure plots the average quarterly education spending by the age profile of the oldest dependent in a household. Panel A reports the unconditional (solid) and unconditional (dotted) averages in spending, and panel B reports the average spending as a share of self-employed households' non-durable consumption. The shaded area in grey indicates the period in which the dependents are most likely to be enrolled in college (1823). Total education spending captures payments to post-secondary institutions (tuition, fees, room and board), testing service agencies (e.g., ETS), and student loan payments to student loan servicing and lending institutions (e.g., Sallie Mae, Navient, Nelnet, etc). Non-durable consumption includes household spending on non-durable goods and services excluding a child's education spending.

A. Average Quarterly Spending on Education

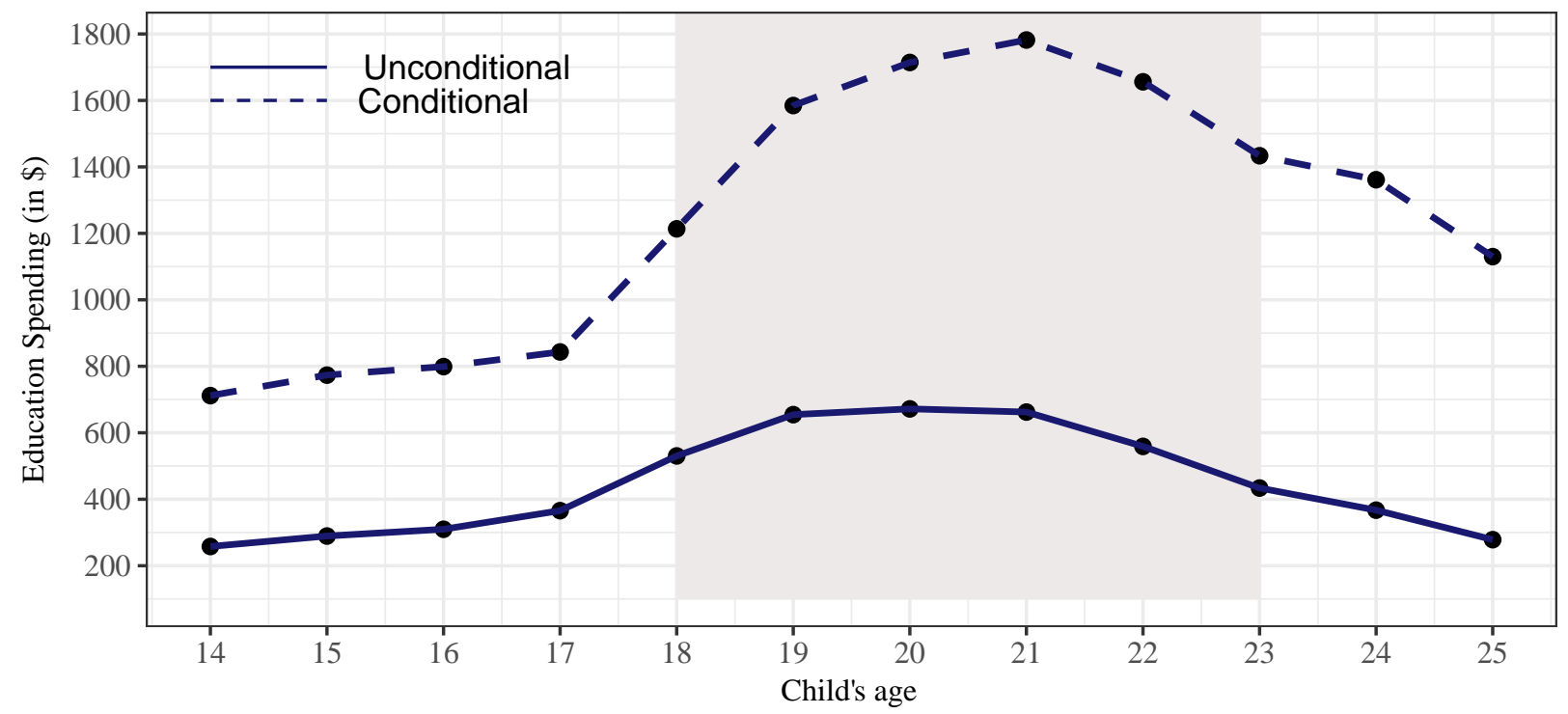

B. Share of Non-Durable Consumption

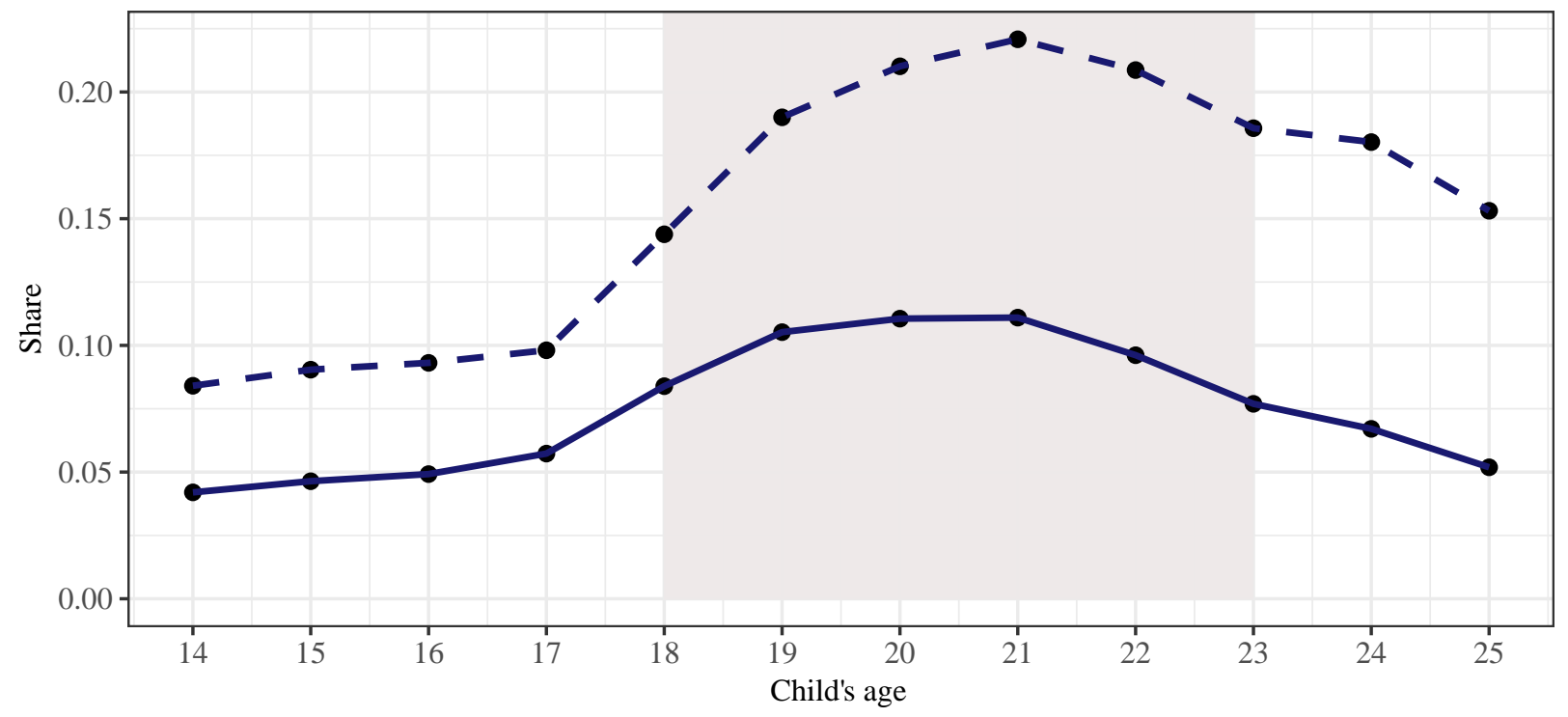


Figure 2: Average Business Outcomes over a Child's Age Profile

Notes: This figure plots the unconditional average of quarterly business outcomes by the age profile of the oldest dependent in a household. The shaded area in grey indicates the period in which the dependents are most likely to be enrolled in college (18-23).

\section{A. Expenses}

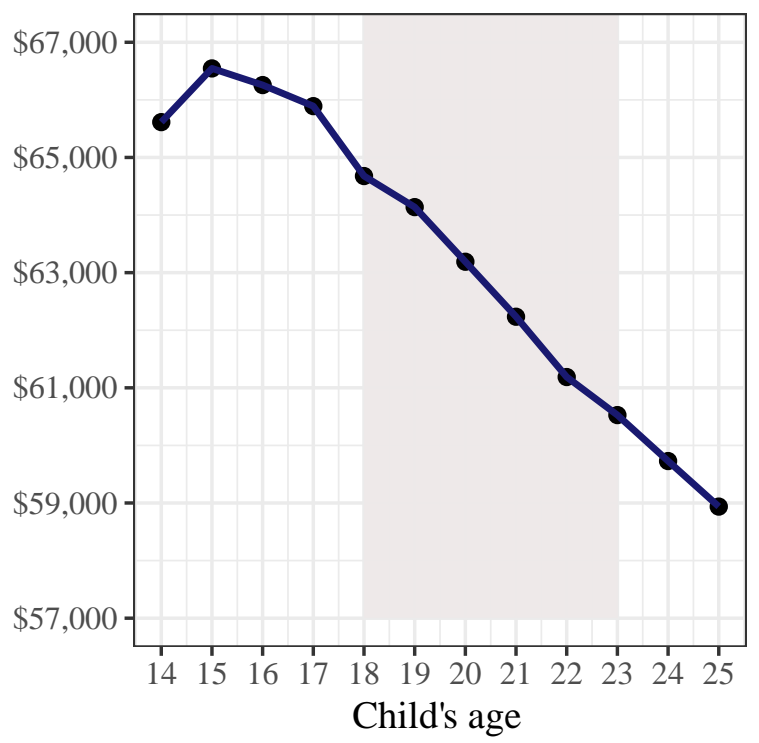

C. Machinery

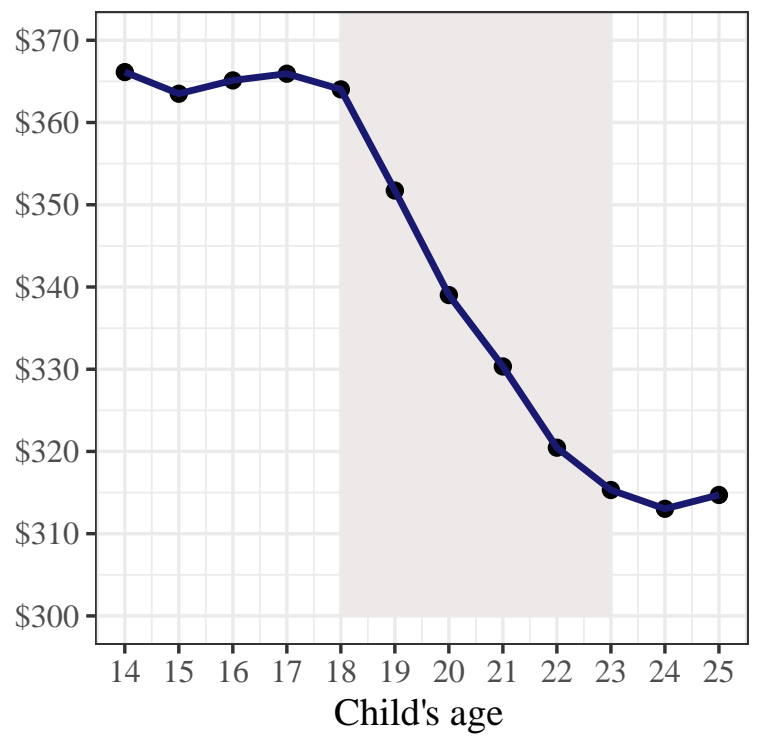

B. Revenues

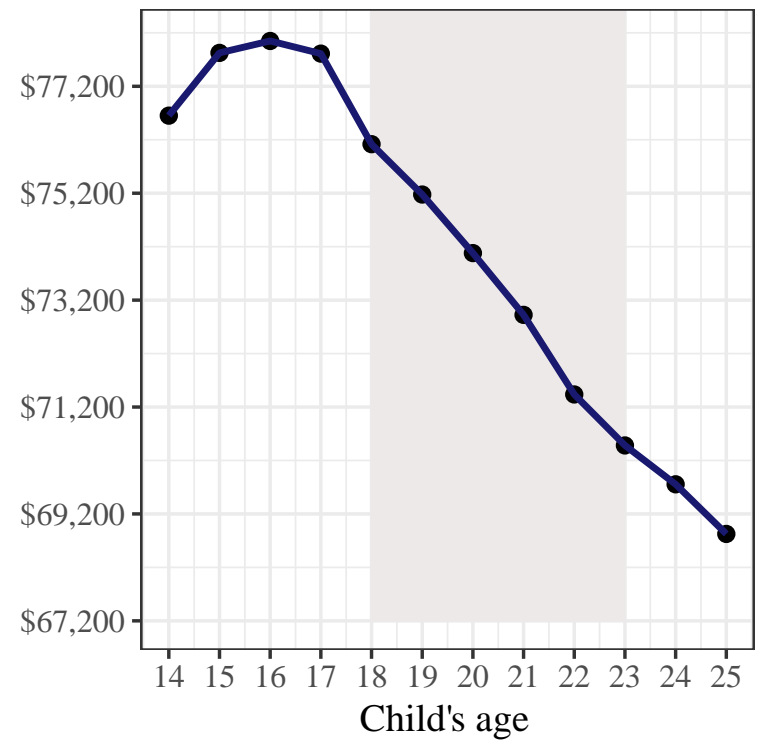

D. Exit Rates

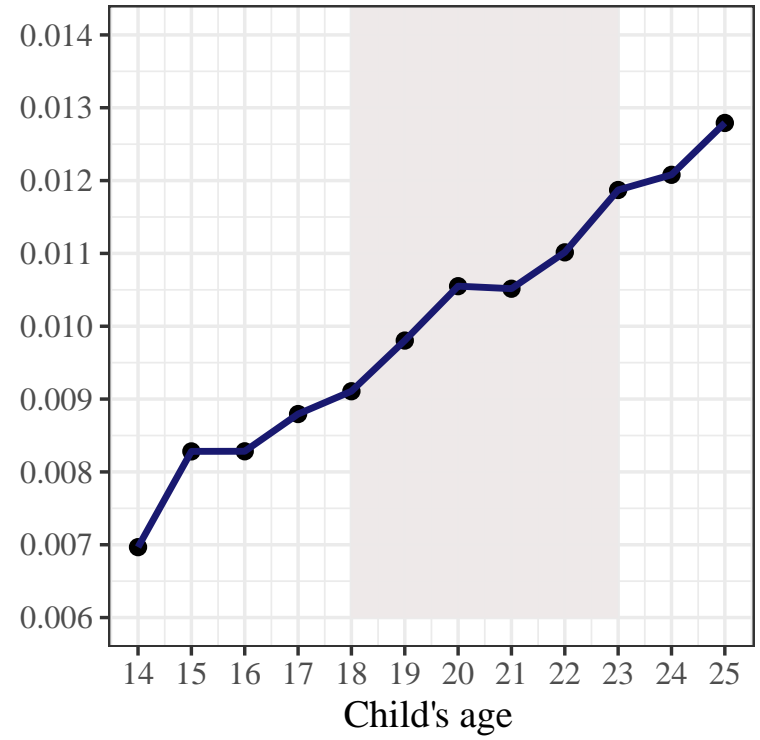




\section{Figure 3: Reduced Form Effects on Business Outcomes}

Notes: This figure plots $\beta_{a}$ of equation 4, which captures the average effect of self-employed households having an $a$-year old dependent. The outcomes are scaled by household-specific baseline average, where the baseline period denotes the period before a child becomes 18 years old. The baseline period is the entire sample range for households that have dependents but do not have 18-19 year olds during the sample period I analyze. All regressions control for the age of the business owner, the number of dependents in a household, business industry and location, and employer status of a business. Whiskers show 95\% confidence intervals. Solid fitted lines are estimated from local regressions.

A. Expenses

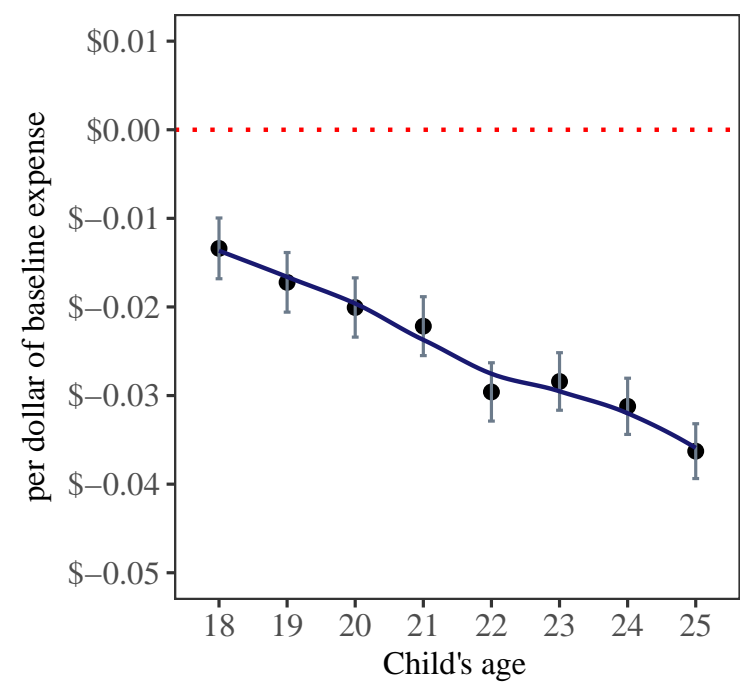

C. Machinery

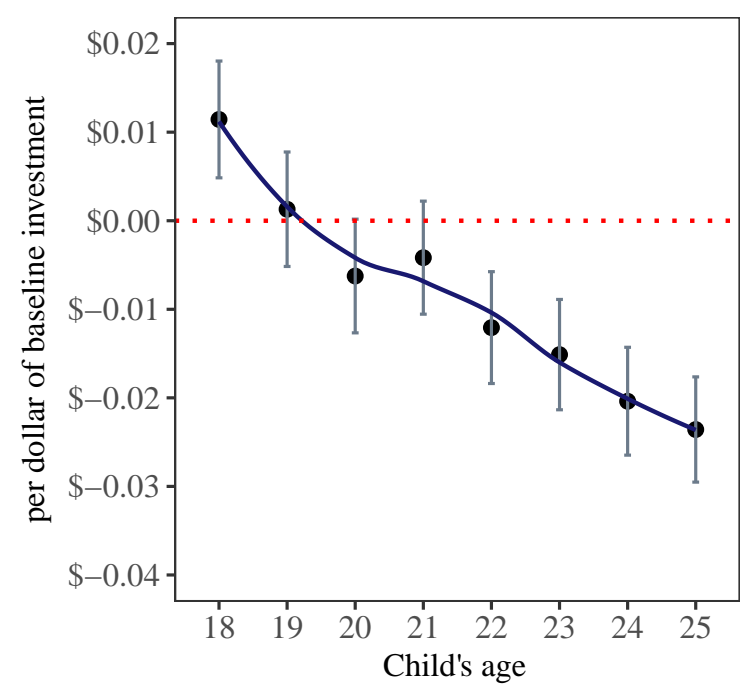

B. Revenues

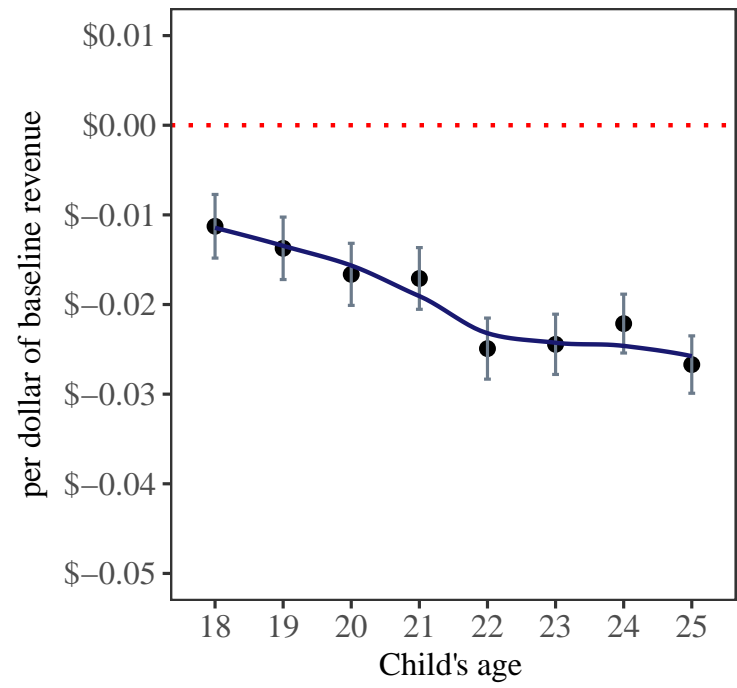

D. Exit rates

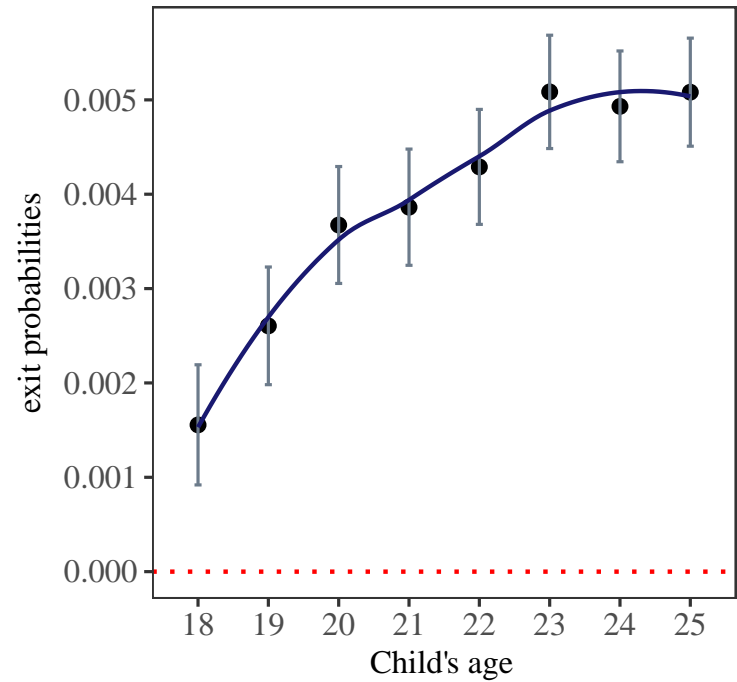




\section{Figure 4: Education Spending Patterns of Treated and Control Households}

Notes: This figure plots quarterly education spending patterns against calendar time for self-employed households with college-entering dependents ("treated" group with 18-19 year olds) and those with near collegeentering dependents ("control" group with 15-17 year olds). Dotted vertical lines mark the third quarter of each calendar year to show that seasonal spikes in education spending coincides with the academic billing cycle. This figure illustrates the motivation behind using the age of a child interacted with quarter-dummies as instruments for education spending.

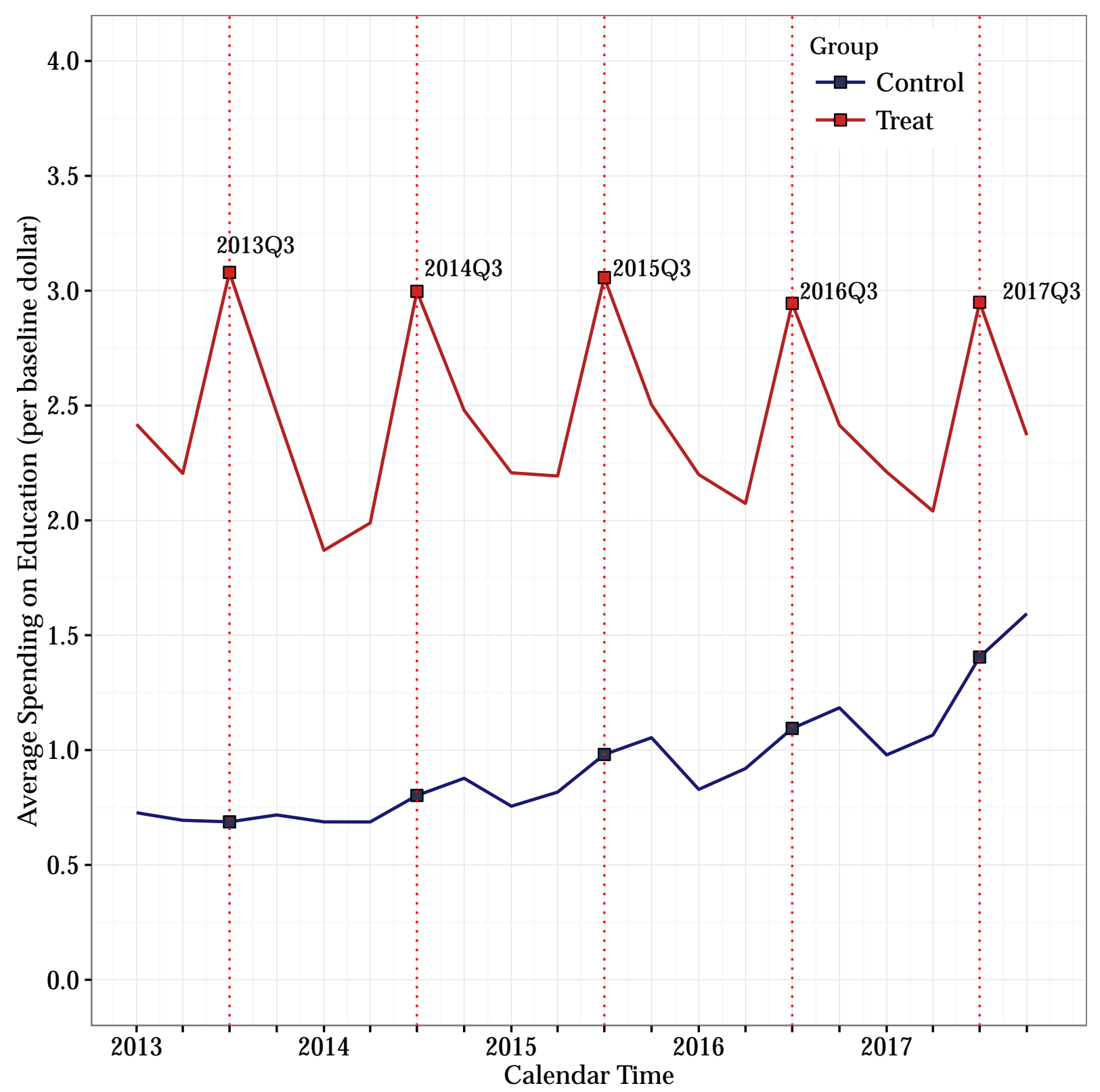




\section{Figure 5: The Effect of Education Spending on Business Performance}

Notes: This figure plots the first stage and reduced form estimates $\beta_{t}$ from equation 2, which capture the effect of a dependent becoming college-entering age on education spending and business outcomes for each quarterto-quarter transition. The sample is restricted to self-employed households with dependents aged between 15 and 19, where households with younger than 18 year olds are in the control group and those with 18 or 19 year olds are in the treated. The IV estimates $-\rho$ - from equation 3 , which capture the business effects induced by increased education spending, are annotated in panel B. All regressions control for the age of the business and its owner, the number of dependents in a household, business industry, state of residence, and employer status of a business. The estimates are also reported in table 3. Whiskers show $95 \%$ confidence intervals and standard errors are clustered at the household-level.

\section{A. First Stage}

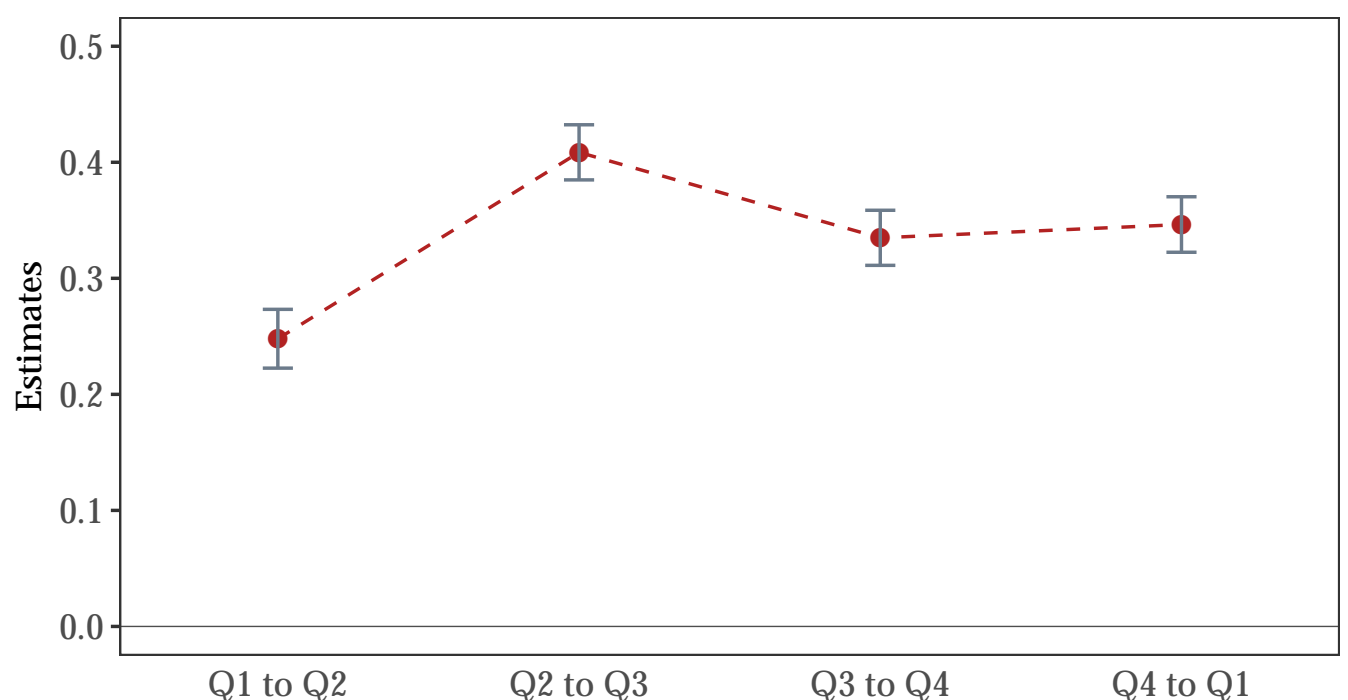

B. Reduced Form

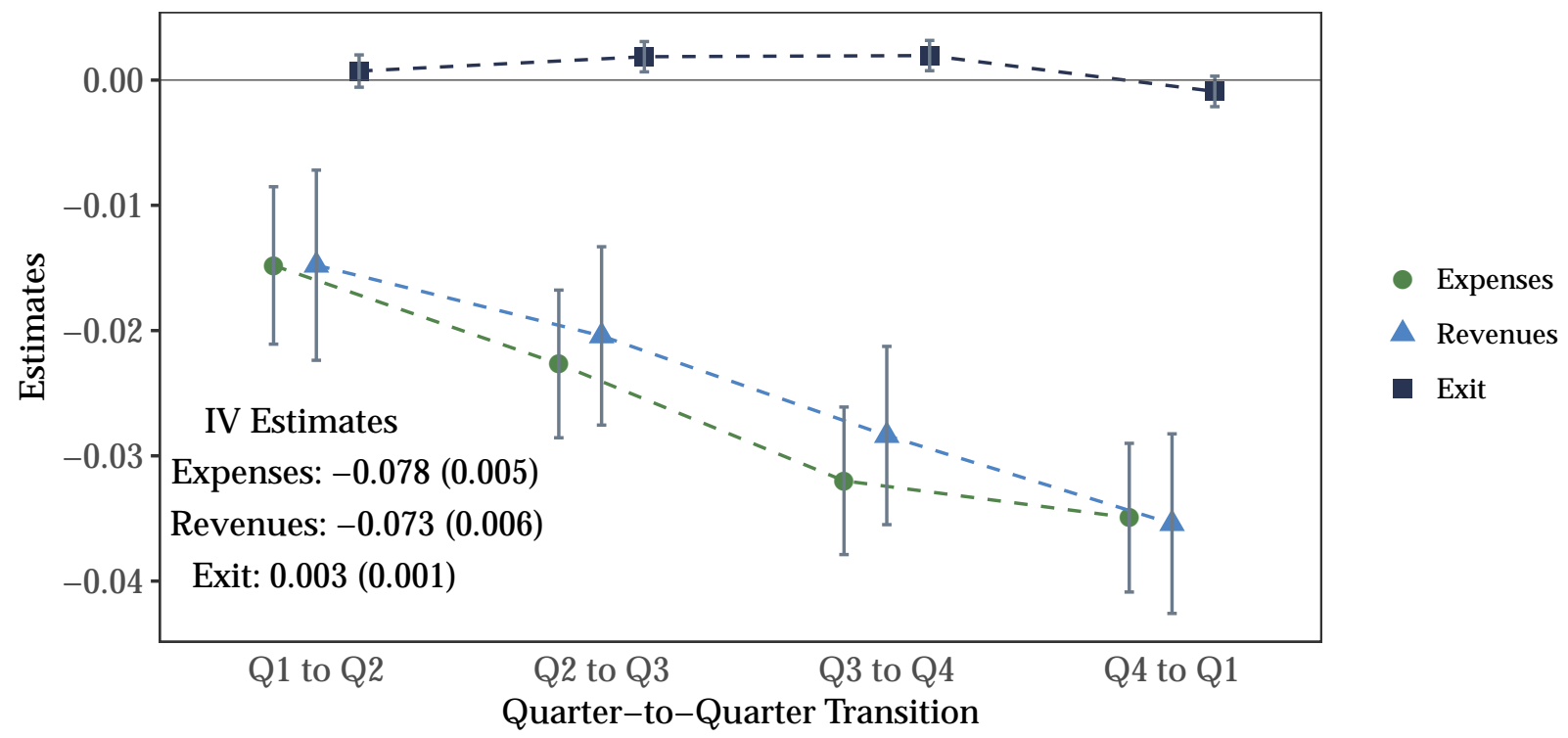




\section{Figure 6: The Effect of Education Spending on Business Expenditures}

Notes: This figure plots the reduced form and IV estimates of the effect of education spending on various business expenditures. The sample is restricted to self-employed households with dependents aged between 15 and 19 , where households with younger than 18 year olds are in the control group and those with 18 or 19 year olds are in the treated. Panel A plots the reduced form estimates $\beta_{t}$, which capture the effect of a dependent becoming college-entering age on various business expenditures for each quarter-to-quarter transition. Panel B plots the IV estimates $-\rho$ - from equation 3 , which capture the business spending effects induced by increased education spending. Auto maintenance includes spending at auto repair shops. Home improvement includes spending on office furnitures, restoration services, or upholstery. Machinery includes spending on industrial equipments, durable appliances, or expenditures at auto dealerships. Utilities include cable, electric, gas, telecommunications, or water. All regressions control for the age of the business and its owner, the number of dependents in a household, business industry, state of residence, and employer status of a business. The estimates are also reported in table 3 . Whiskers show $95 \%$ confidence intervals and standard errors are clustered at the householdlevel.

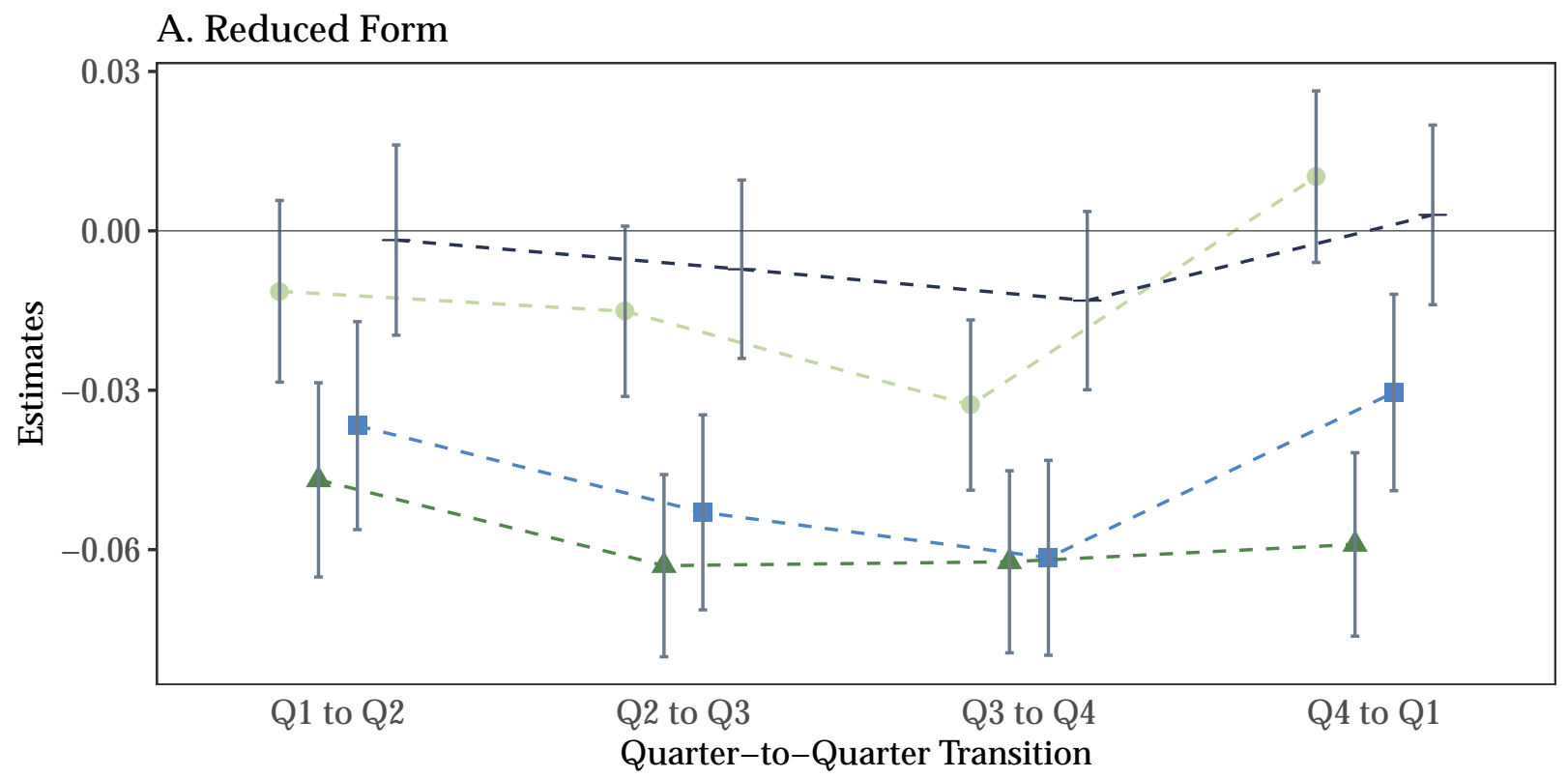

B. IV Estimates

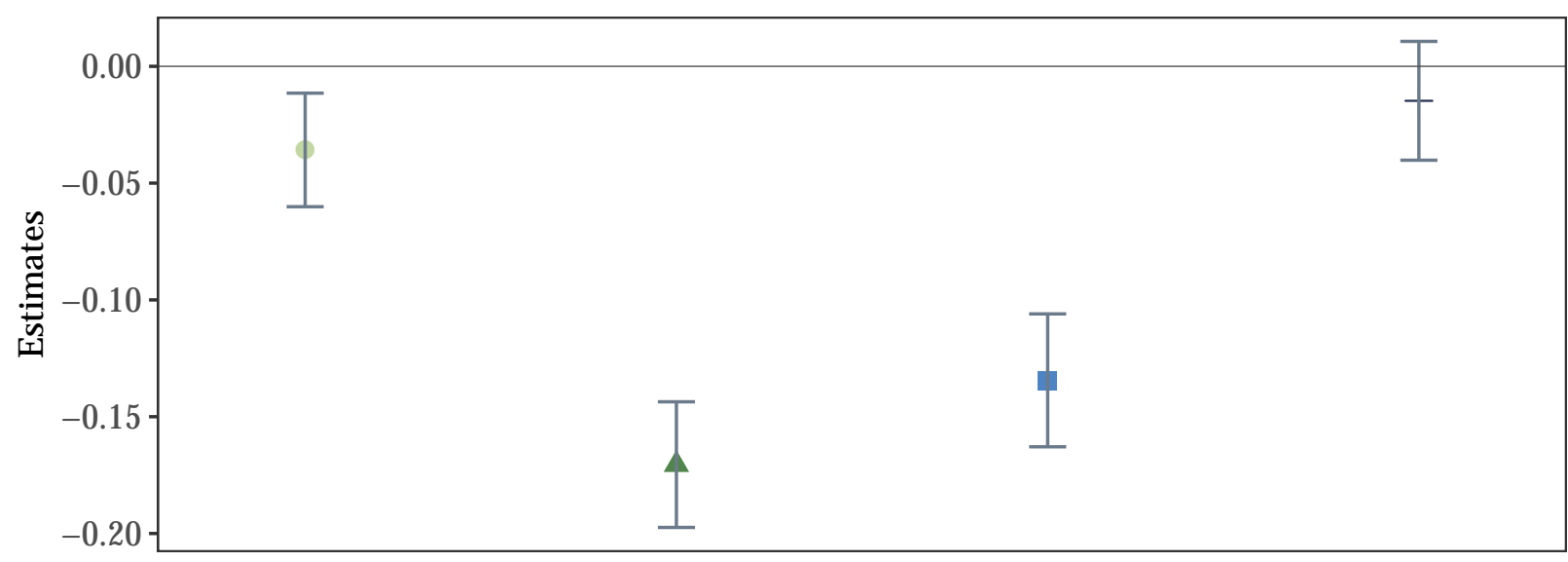




\section{Figure 7: The Effect of Education Spending on Household Consumption}

Notes: This figure plots the reduced form and IV estimates of the effect of education spending on household consumption net of education spending. The sample is restricted to self-employed households with dependents aged between 15 and 19, where households with younger than 18 year olds are in the control group and those with 18 or 19 year olds are in the treated. Panel A plots the reduced form estimates $\beta_{t}$, which capture the effect of a dependent becoming college-entering age on household consumption for each quarter-to-quarter transition. Panel B plots the IV estimates $-\rho$ - from equation 3, which capture the consumption effects induced by increased education spending. Detailed information on consumption categories are available in table A.6. All regressions control for the age of the business and its owner, the number of dependents in a household, business industry, state of residence, and employer status of a business. The estimates are also reported in table 4. Whiskers show $95 \%$ confidence intervals and standard errors are clustered at the household-level.

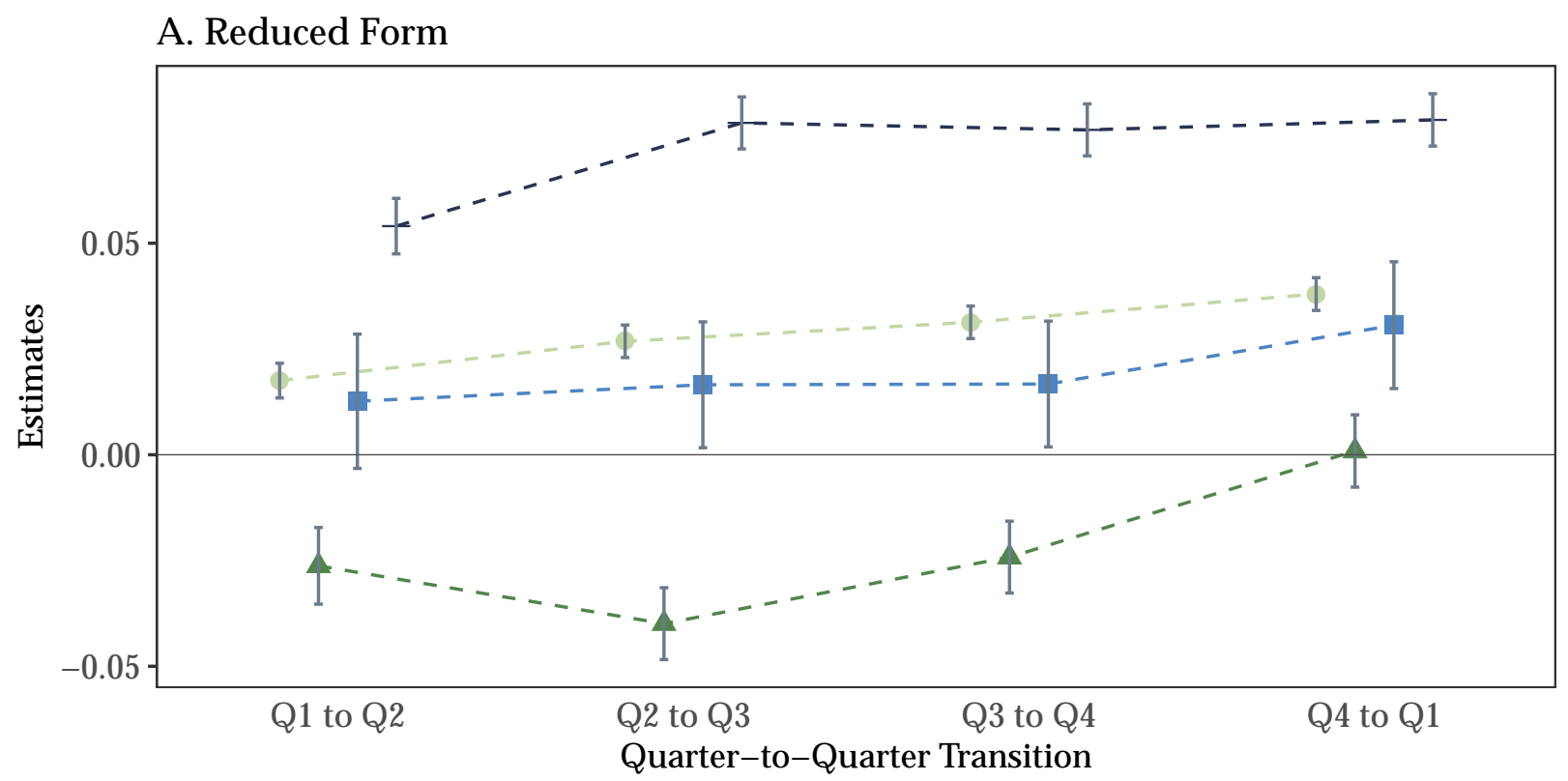

B. IV Estimates

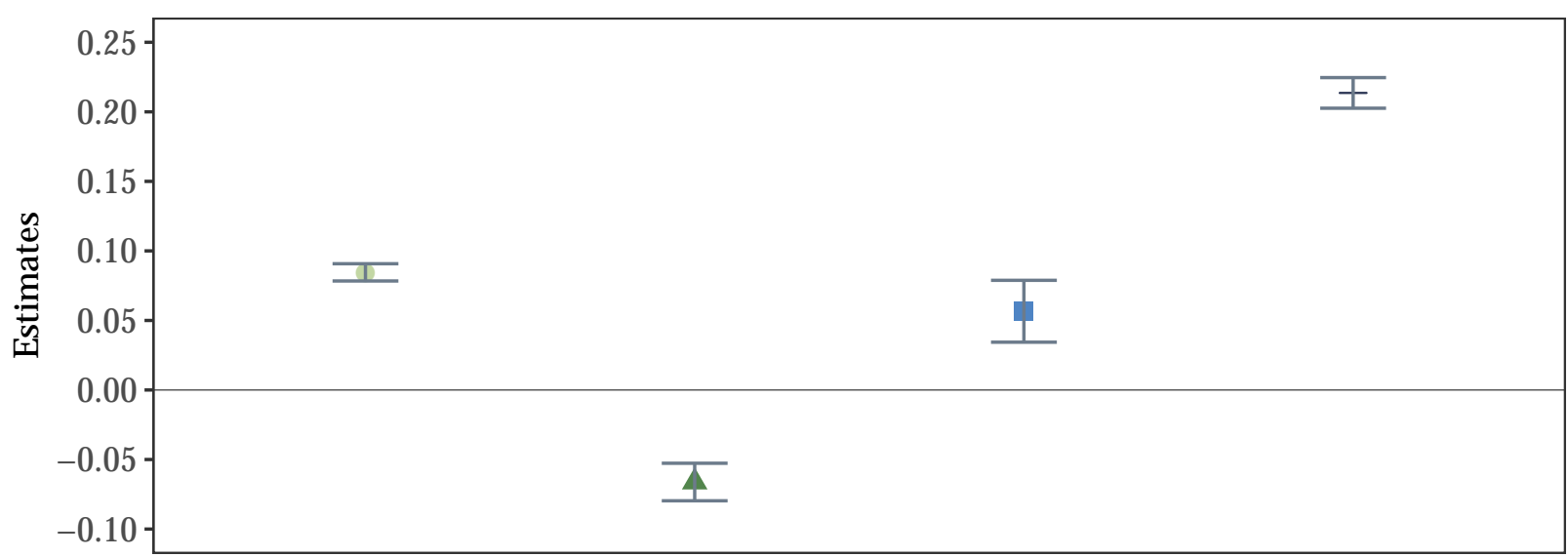

Consumption (net) $\Delta$ Non-durable Goods D Durable Goods + Services (net) 


\section{Figure 8: The Effect of Education Spending on Consumption Composition}

Notes: This figure plots the reduced form and IV estimates of the effect of education spending on household consumption net of education spending. The sample is restricted to self-employed households with dependents aged between 15 and 19, where households with younger than 18 year olds are in the control group and those with 18 or 19 year olds are in the treated. Panel A plots the reduced form estimates $\beta_{t}$, which capture the effect of a dependent becoming college-entering age on household consumption for each quarter-to-quarter transition. Panel B plots the IV estimates $-\rho$ - from equation 3, which capture the consumption effects induced by increased education spending. Groceries include spending at grocery stores or supermarkets. Restaurants include spending at restaurants, fast food chains, coffee shops, or bakeries. Medical expenses include dentist, doctor, or health practitioner visits. Utilities include cable, electric, gas, telecommunications, or water. Mortgage indicates mortgage payments. All regressions control for the age of the business and its owner, the number of dependents in a household, business industry, state of residence, and employer status of a business. The estimates are also reported in table 4 . Whiskers show $95 \%$ confidence intervals and standard errors are clustered at the household-level.

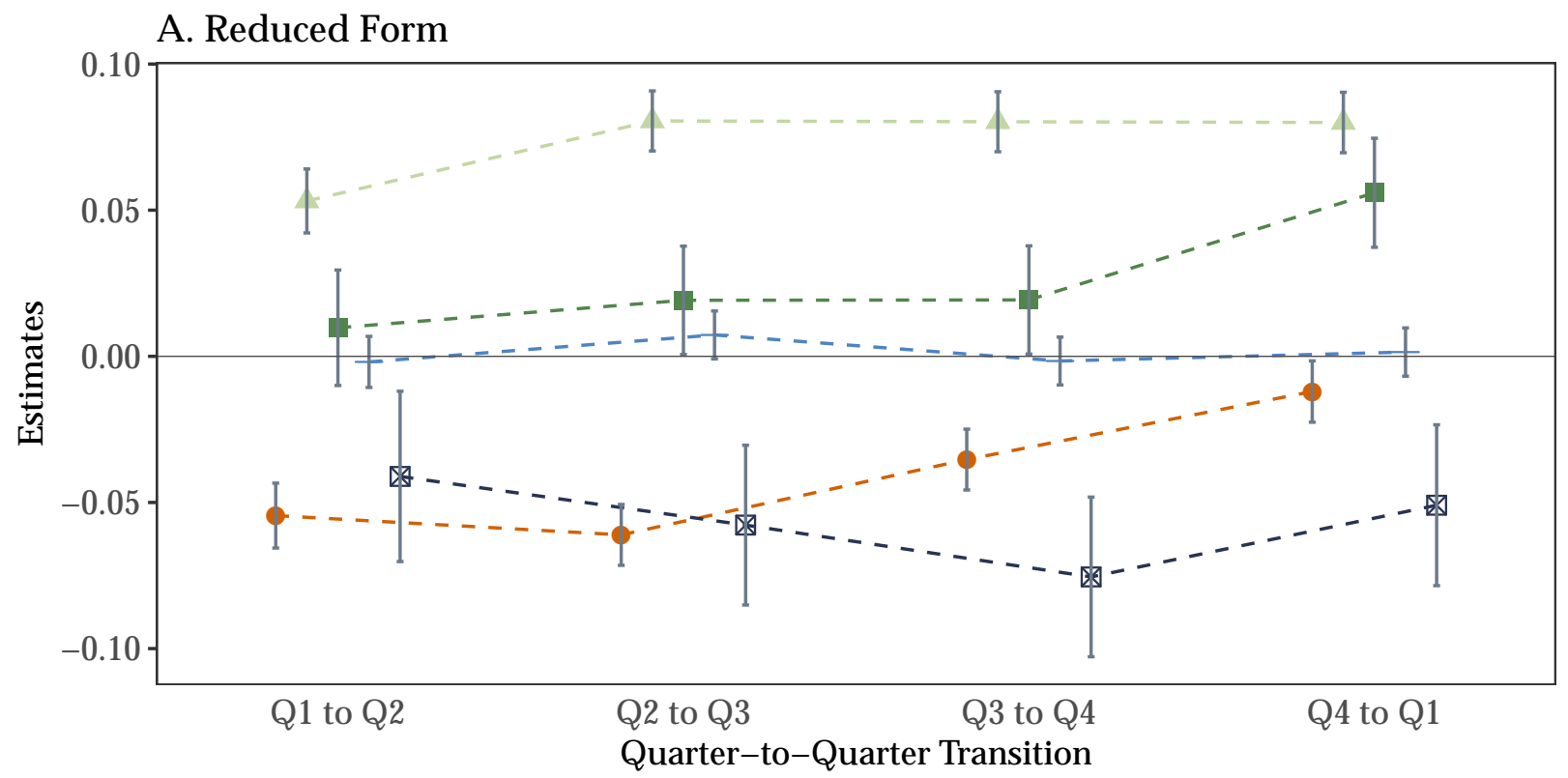

B. IV Estimates

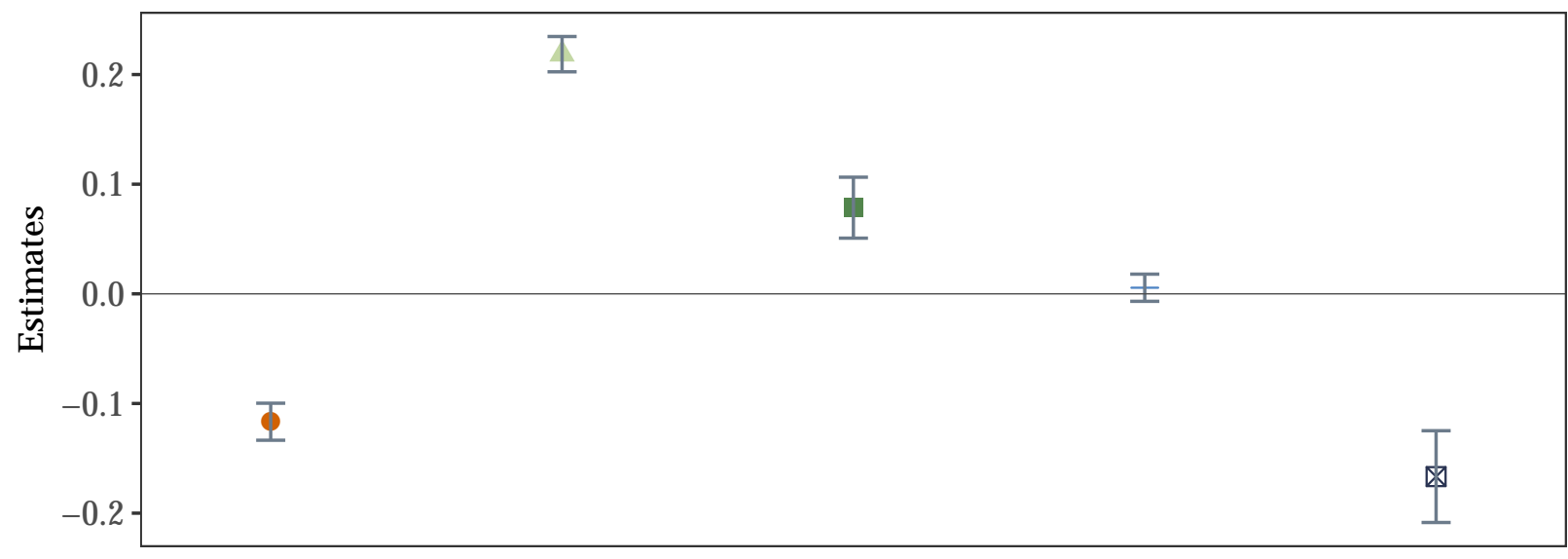

- Groceries $\Delta$ Restaurants $\square$ Medical + Utility $\otimes$ Mortgage 


\section{Figure 9: Business Effects by Average Growth Rates}

Notes: This figure plots $\beta_{a}$ of equation 4, which captures the effect of self-employed households having an $a$ year old dependent on business expenses and revenues by businesses with different business growth propensities. Business growth rates are calculated as the average year-over-year revenue growth before a child turns 18 years old. Self-employed households are grouped into quartile bins by average growth rates. Bin 1 includes firms with the lowest pre-18 average growth rates and bin 4 includes those with the highest pre-18 growth rates. The sample is restricted to self-employed households that ever had 18 or 19 year olds during the sample period I analyze. All regressions control for the age of the business and its owner, the number of dependents in a household, business industry, state of residence, and employer status of a business. Whiskers show $95 \%$ confidence intervals and standard errors are clustered at the household-level.

\section{A. Expenses}

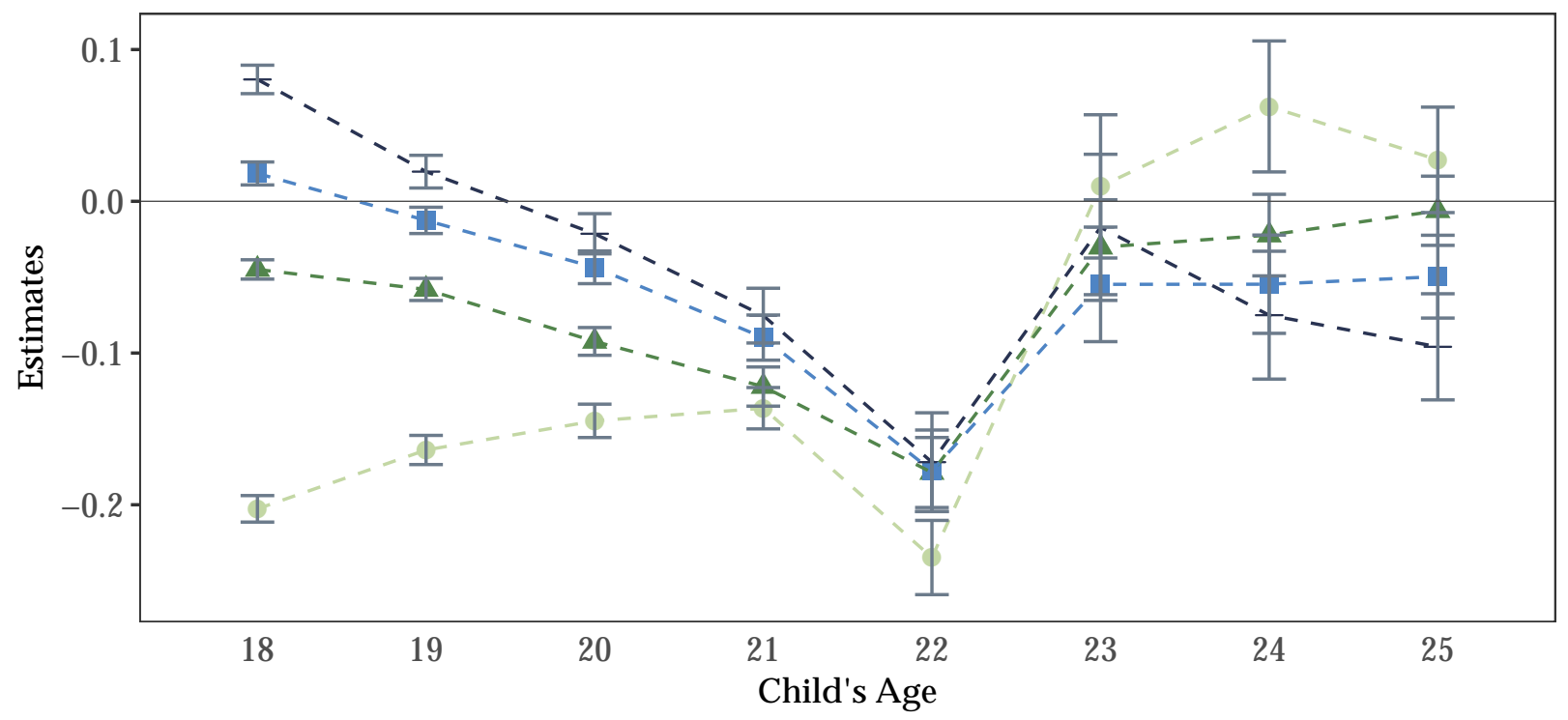

B. Revenues

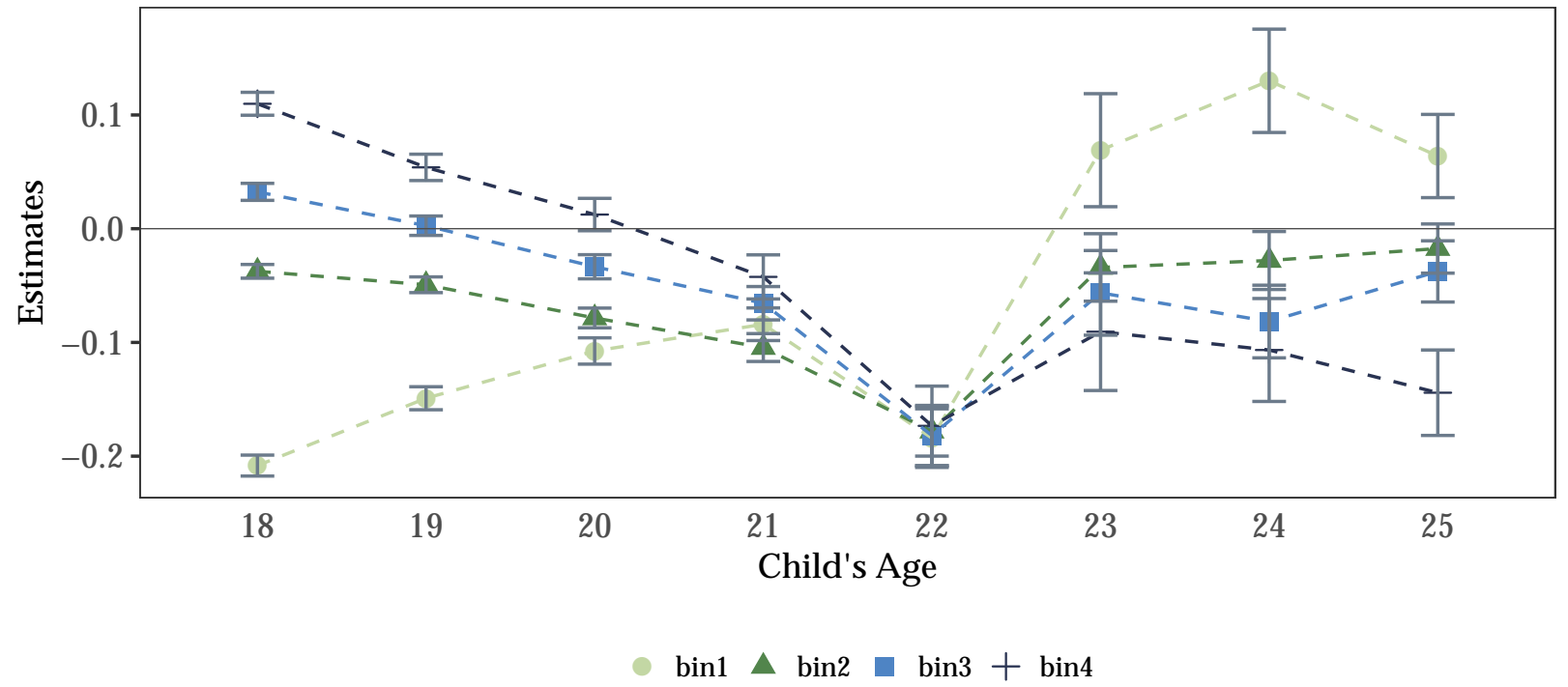




\section{Figure 10: Household Consumption Effects by Average Growth Rates}

Notes: This figure plots $\beta_{a}$ of equation 4, which captures the effect of self-employed households having an $a$ year old dependent on household consumption net of education expenditure by businesses with different business growth propensities. Business growth rates are calculated as the average year-over-year revenue growth before a child turns 18 years old. Self-employed households are grouped into quartile bins by average growth rates. Bin 1 includes firms that has the lowest pre-18 average growth rates and bin 4 includes those with the highest pre-18 growth rates. The sample is restricted to self-employed households that ever had 18 or 19 year olds during the sample period. All regressions control for the age of the business and its owner, the number of dependents in a household, business industry, state of residence, and employer status of a business. Whiskers show $95 \%$ confidence intervals and standard errors are clustered at the household-level.

\section{A. Consumption}

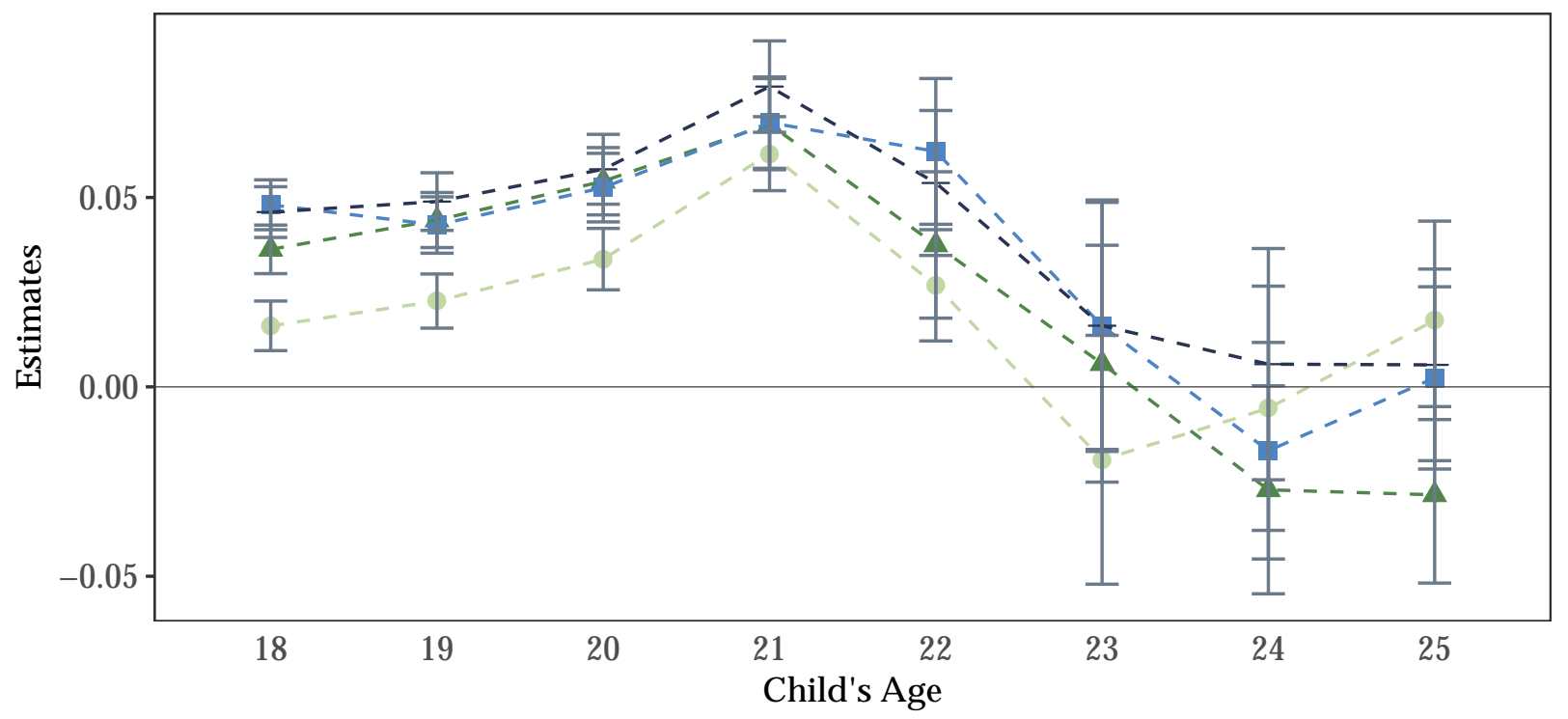

\section{B. Non-durable Goods}

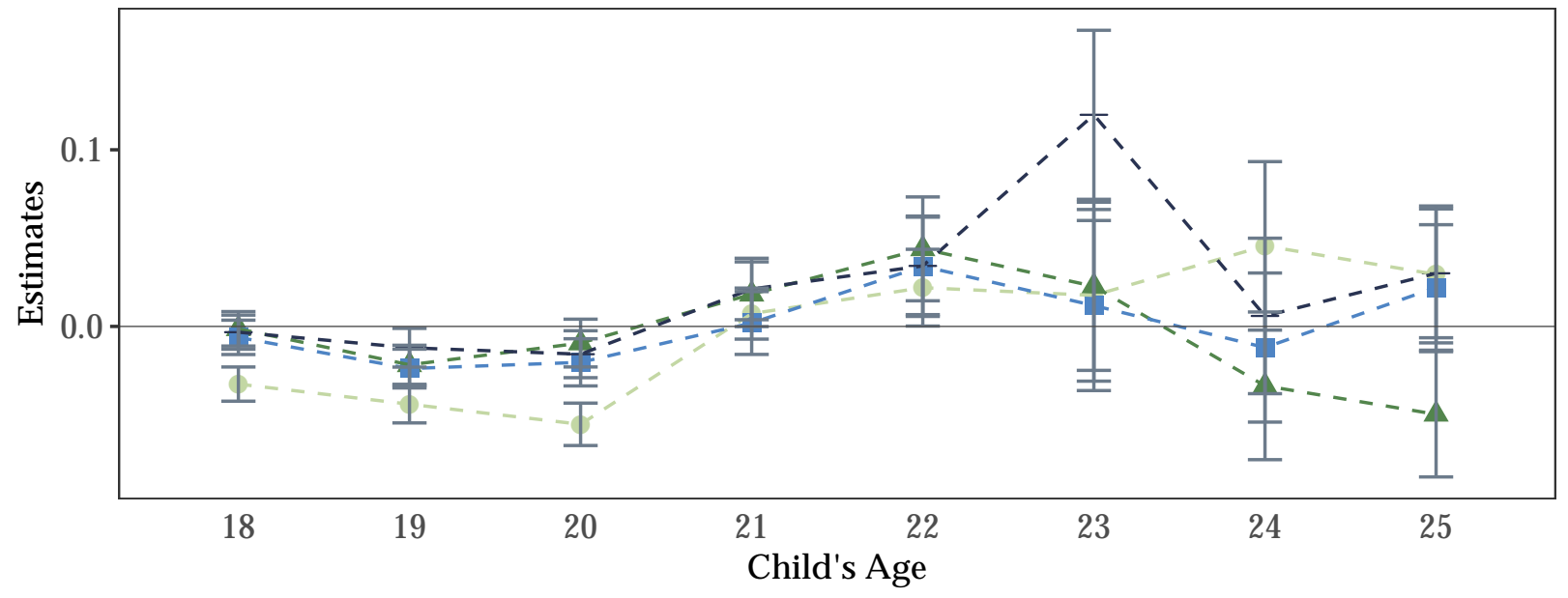

$\operatorname{bin} 1 \Delta \operatorname{bin} 2 \square \operatorname{bin} 3+\operatorname{bin} 4$ 


\section{Figure 11: Heterogeneity in Post-Exit Response}

Notes: This figure plots $\beta_{s}$ from equation 5 by subgroups of households that exit before a child is 18 years old and those that exit after. The exit timing may capture the degree of financial constraint that a households experiences- households that exit before a child reaches college-entering age may be forward-looking households whereas those that exit after may have been induced to exit due to high spending burden. Consumption captures total household consumption net of education spending. Nondurable goods capture household spending on nondurable goods. Labor income refers to any direct deposits and payroll income from employer or payroll processor companies. Gig income refers to any income derived from participating in the online platform economy (labor, capital non-transport, and leasing platforms). Solid fitted lines are estimated from local regressions, and $95 \%$ confidence bands of the fitted lines are shown in grey. All regressions control for the age of the business owner, the number of dependents in a household, business industry and location, and employer status of a business.

A. Consumption

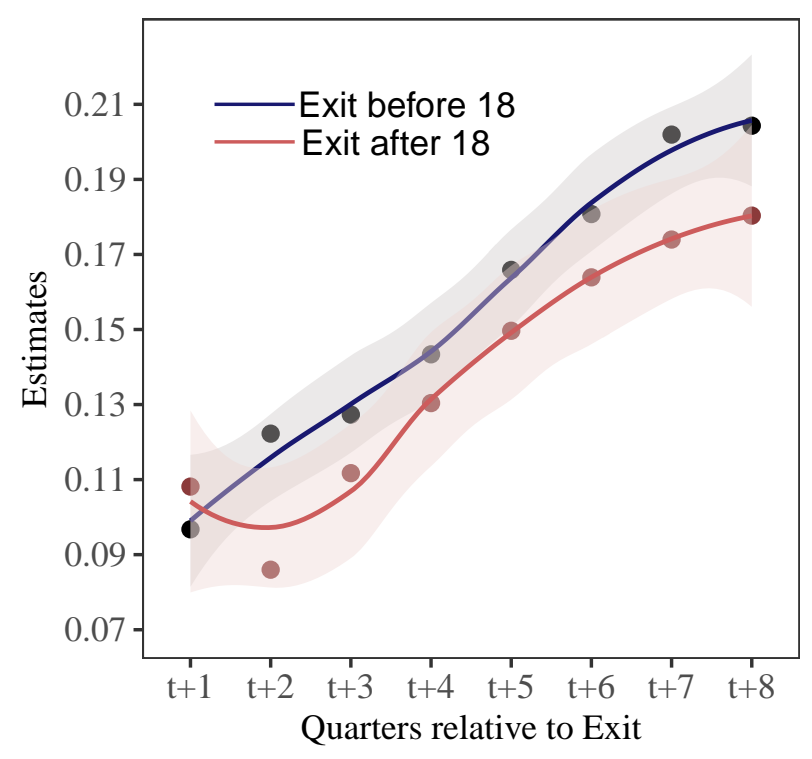

C. Labor Income

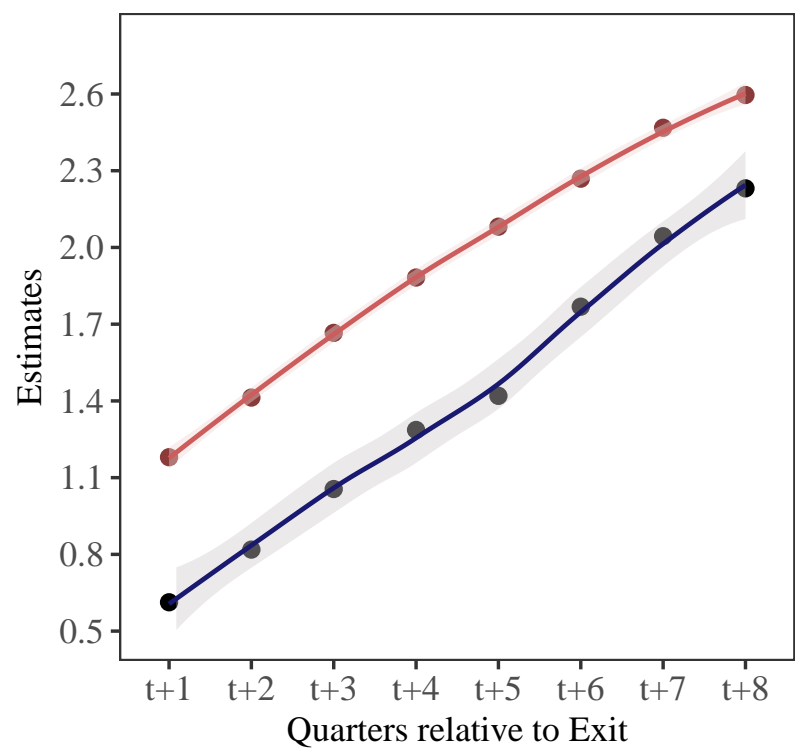

\section{B. Nondurable Goods}

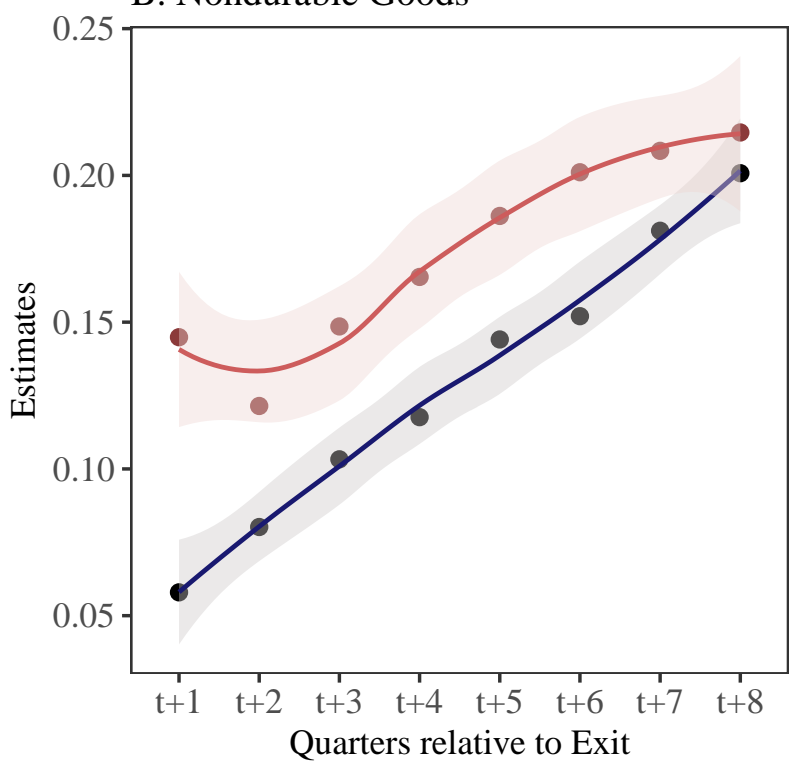

D. Gig Economy Income

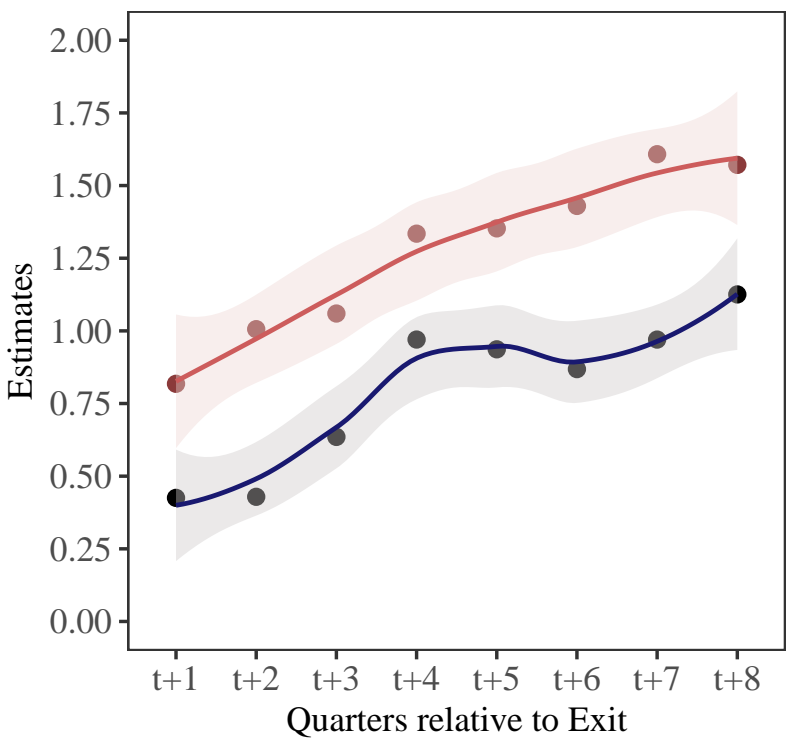




\section{Table 1: Descriptive Statistics}

Notes: This table reports descriptive statistics for household and business characteristics. Business outcomes are reported at the quarterly frequency in USD. To preserve anonymity, statistics are presented as means of ten observations in the $p^{\text {th }}$ percentiles. The top panel reports descriptive statistics of all self-employed households with children of age between 14 and 25. The bottom panel restricts the sample size to the baseline regression sample with children of age between 15 and 19. Parent's age corresponds to the age of the oldest member in a household, and the child's age corresponds to the age of the oldest dependent in a household. Sample ranges from 2012 Q4 to 2018 Q2.

\begin{tabular}{cccccc}
\hline Mean & SD & $\mathrm{p} 25$ & $\mathrm{p} 50$ & $\mathrm{p} 75$ \\
& $(1)$ & $(2)$ & $(3)$ & $(4)$ & $(5)$ \\
\hline
\end{tabular}

\section{All Sample}

Number of family members

Number of dependents

Parent's age

A. Household Characteristics

Child's age

$\begin{array}{ccccc}3 & 1 & 3 & 3 & 4 \\ 1 & 0.6 & 1 & 1 & 2 \\ 52 & 11 & 47 & 52 & 58 \\ 21 & 3 & 18 & 21 & 23\end{array}$

Business years in operation

Business revenue

B. Business Characterisristics

$\begin{array}{ccccc}6 & 6 & 2 & 5 & 8 \\ 73,165 & 115,810 & 5,303 & 23,344 & 78,581 \\ 62,472 & 103,755 & 4,029 & 16,967 & 63,700\end{array}$

Business expense

$$
62,472 \quad 103,755
$$

4,029

63,700

Professional Services

C. Share of firms in top 3 industry and location

Other Services (exc. Public Services)

$\begin{array}{lll}0.16 & \text { California } & 0.18 \\ 0.12 & \text { New York } & 0.17 \\ 0.10 & \text { Texas } & 0.15\end{array}$

Construction

0.10 Texas

0.15

Number of households $148,275 \quad 148,275$

148,275

$148,275 \quad 148,275$

\section{Regression Sample}

A. Household Characteristics

Number of family members

Number of dependents

Parent's age

$3 \quad 1$

1

0.5

51

0.5

$\begin{array}{ccc}3 & 3 & 4 \\ 1 & 1 & 1 \\ 45 & 49 & 55 \\ 16 & 17 & 19\end{array}$

$51 \quad 10$

$\begin{array}{ccc}3 & 3 & 4 \\ 1 & 1 & 1 \\ 45 & 49 & 55 \\ 16 & 17 & 19\end{array}$

$17 \quad 1.5$

$\begin{array}{ccc}3 & 3 & 4 \\ 1 & 1 & 1 \\ 45 & 49 & 55 \\ 16 & 17 & 19\end{array}$

B. Business Characteristics

Business years in operation

$$
6 \quad 6
$$

2

$\begin{array}{ll}4 & 8\end{array}$

Business revenue

$76,726 \quad 118,482$

5,894

25,324

84,395

Business expense

$65,278 \quad 106,097$

4,383

18,260

67,986

C. Share of firms in top 3 industry and location

Professional Services

$\begin{array}{lll}0.17 & \text { California } & 0.17 \\ 0.11 & \text { Texas } & 0.16 \\ 0.11 & \text { New York } & 0.15\end{array}$

Construction

0.11 New York

0.15

Number of households

$61,684 \quad 61,684 \quad 61,684$

61,684

61,684 


\section{Table 2: Quarterly Spending in Education}

Notes: This table reports mean and standard deviation of quarterly education spending for self-employed households with children. Panels A and B compare statistics for households with 15-17 year olds ("Near College-Entering Sample") and those with 18-19 year olds ("College-Entering Sample"). Panels C and D compare statistics for households with 18-22 year olds ("College-Going Sample") and those with 23-25 year olds ("College-Graduating Sample"). Each panel reports unconditional and conditional statistics where unconditional statistics pool households with dependents of referenced age group, and conditional statistics pool those with positive education spending. Total education spending includes any payments to post-secondary institutions, testing service agencies, student loan servicing companies, and savings to 529 accounts. 529 drawdowns and savings are defined by transfers between 529 accounts and personal or business accounts.

\begin{tabular}{|c|c|c|c|c|c|c|c|c|}
\hline Outcomes $(\$)$ & $\begin{array}{c}\text { Mean } \\
\text { (1) }\end{array}$ & $\begin{array}{l}\text { SD } \\
(2)\end{array}$ & $\begin{array}{c}\text { Mean } \\
\text { (3) }\end{array}$ & $\begin{array}{l}\text { SD } \\
(4)\end{array}$ & $\begin{array}{c}\text { Mean } \\
(5)\end{array}$ & $\begin{array}{l}\text { SD } \\
(6)\end{array}$ & $\begin{array}{l}\text { Mean } \\
(7)\end{array}$ & $\begin{array}{l}\text { SD } \\
(8)\end{array}$ \\
\hline & \multicolumn{4}{|c|}{ A. Near College-Entering Sample } & \multicolumn{4}{|c|}{ B.College-Entering Sample } \\
\hline & \multicolumn{2}{|c|}{ Unconditional } & \multicolumn{2}{|c|}{ Conditional } & \multicolumn{2}{|c|}{ Unconditional } & \multicolumn{2}{|c|}{ Conditional } \\
\hline Total Education Spending & 321 & 1,690 & 803 & 2,597 & 595 & 3,114 & 1,401 & 4,650 \\
\hline 529 Drawdowns & 5 & 509 & 11,037 & 20,075 & 26 & 847 & 11,103 & 13,523 \\
\hline 529 Savings & 26 & 572 & 2,199 & 4,763 & 26 & 676 & 2,590 & 6,207 \\
\hline \multirow[t]{3}{*}{ Student Loan Payments } & 125 & 3,567 & 1,216 & 11,056 & 203 & 15,485 & 1,762 & 45,648 \\
\hline & \multicolumn{4}{|c|}{ C. College-Going Sample } & \multicolumn{4}{|c|}{ D.College Graduating Sample } \\
\hline & \multicolumn{2}{|c|}{ Unconditional } & \multicolumn{2}{|c|}{ Conditional } & \multicolumn{2}{|c|}{ Unconditional } & \multicolumn{2}{|c|}{ Conditional } \\
\hline Total Education Spending & 617 & 2,951 & 1,588 & 4,563 & 356 & 3,052 & 1,311 & 5,741 \\
\hline 529 Drawdowns & 26 & 803 & 10,485 & 12,385 & 12 & 467 & 8,537 & 9,205 \\
\hline 529 Savings & 21 & 525 & 2,536 & 5,247 & 9 & 285 & 2,149 & 3,822 \\
\hline Student Loan Payments & 253 & 22,825 & 1,971 & 63,699 & 255 & 2,003 & 1,480 & 4,634 \\
\hline
\end{tabular}




\section{Table 3: The Effect of Education Spending on Business Outcomes}

Notes: This table reports first stage, reduced form, and 2SLS estimates of business response of sending kids to college using the college-entering sample that compares business outcomes of self-employed households with near college-entry age children (15-17 year-olds, or "control") to that of households with college-going age (18-19 year-olds, or "treatment") children. Column 1 reports control mean in levels. Columns 2 - 5 report $\beta_{t}$ from respective first stage or reduced form regressions. The first row reports the estimates from the first stage equation 2, and the bottom rows report the reduced form estimates. Column 6 reports the TSLS-IV estimate $\rho$ from equation 3. All regressions control for the age of the business and its owner, the number of dependents in a household, business industry, state of residence of a household, and employer status of a business. Standard errors are clustered at the household-level and reported in parentheses. $* * * \mathrm{p}<0.01, * * \mathrm{p}<0.05, * \mathrm{p}<0.10$

\begin{tabular}{|c|c|c|c|c|c|c|c|c|c|c|c|}
\hline \multirow{2}{*}{$\begin{array}{l}\text { Outcome } \\
\text { Variables }\end{array}$} & \multirow{2}{*}{$\begin{array}{c}\text { Control } \\
\text { Mean } \\
\text { (1) }\end{array}$} & \multicolumn{7}{|c|}{ Quarter Transitions $\times \mathbb{1}($ College-entering age $)$} & \multicolumn{3}{|c|}{$\begin{array}{c}\text { TSLS } \\
\text { Estimates }\end{array}$} \\
\hline & & $\begin{array}{l}\text { I to II } \\
\text { (2) }\end{array}$ & & $\begin{array}{l}\text { II to III } \\
\text { (3) }\end{array}$ & & $\begin{array}{l}\text { III to IV } \\
\text { (4) }\end{array}$ & & $\begin{array}{l}\text { IV to I } \\
\text { (5) }\end{array}$ & & $(6)$ & \\
\hline \multicolumn{12}{|c|}{ First Stage } \\
\hline Education Spending & $\$ 354$ & $\begin{array}{l}0.248 \\
(.013)\end{array}$ & $* * *$ & $\begin{array}{l}0.409 \\
(.012) \\
\text { Reduc }\end{array}$ & $\begin{array}{l}* * * \\
\text { Form }\end{array}$ & $\begin{array}{l}0.335 \\
(.012)\end{array}$ & $* * *$ & $\begin{array}{l}0.346 \\
(.012)\end{array}$ & $* * *$ & & \\
\hline Business Expenses & $\$ 67,822$ & $\begin{array}{l}-0.015 \\
(.003)\end{array}$ & $* * *$ & $\begin{array}{l}-0.023 \\
(.003)\end{array}$ & $* * *$ & $\begin{array}{l}-0.032 \\
(.003)\end{array}$ & $* * *$ & $\begin{array}{r}-0.035 \\
(.003)\end{array}$ & $* * *$ & $\begin{array}{l}-0.078 \\
(.005)\end{array}$ & $* * *$ \\
\hline Auto maintenance & $\$ 155$ & $\begin{array}{l}-0.011 \\
(.009)\end{array}$ & & $\begin{array}{l}-0.015 \\
(.008)\end{array}$ & $*$ & $\begin{array}{l}-0.033 \\
(.008)\end{array}$ & $* * *$ & $\begin{array}{l}0.010 \\
(.008)\end{array}$ & & $\begin{array}{l}-0.036 \\
(.012)\end{array}$ & $* * *$ \\
\hline Office supplies/tools & $\$ 735$ & $\begin{array}{l}-0.047 \\
(.009)\end{array}$ & $* * *$ & $\begin{array}{l}-0.053 \\
(.009)\end{array}$ & $* * *$ & $\begin{array}{l}-0.062 \\
(.009)\end{array}$ & $* * *$ & $\begin{array}{l}-0.059 \\
(.009)\end{array}$ & $* * *$ & $\begin{array}{l}-0.171 \\
(.016)\end{array}$ & $* * *$ \\
\hline Machinery & $\$ 375$ & $\begin{array}{c}-0.037 \\
(.01)\end{array}$ & $* * *$ & $\begin{array}{l}-0.053 \\
(.009)\end{array}$ & $* * *$ & $\begin{array}{l}-0.062 \\
(.009)\end{array}$ & $* * *$ & $\begin{array}{l}-0.030 \\
(.009)\end{array}$ & $* * *$ & $\begin{array}{l}-0.134 \\
(.015)\end{array}$ & $* * *$ \\
\hline Utilities & $\$ 854$ & $\begin{array}{l}-0.002 \\
(.009)\end{array}$ & & $\begin{array}{l}-0.007 \\
(.009)\end{array}$ & & $\begin{array}{l}-0.013 \\
(.009)\end{array}$ & & $\begin{array}{l}0.003 \\
(.009)\end{array}$ & & $\begin{array}{l}-0.015 \\
(.013)\end{array}$ & \\
\hline Business Revenues & $\$ 80,557$ & $\begin{array}{l}-0.015 \\
(.004)\end{array}$ & $* * *$ & $\begin{array}{l}-0.020 \\
(.004)\end{array}$ & $* * *$ & $\begin{array}{l}-0.028 \\
(.004)\end{array}$ & $* * *$ & $\begin{array}{l}-0.035 \\
(.004)\end{array}$ & $* * *$ & $\begin{array}{l}-0.073 \\
(.006)\end{array}$ & $* * *$ \\
\hline Exit & 0.009 & $\begin{array}{l}0.001 \\
(.001)\end{array}$ & & $\begin{array}{l}0.002 \\
(.001)\end{array}$ & $* * *$ & $\begin{array}{l}0.002 \\
(.001)\end{array}$ & $* * *$ & $\begin{array}{l}-0.001 \\
(.001)\end{array}$ & & $\begin{array}{l}0.003 \\
(.001)\end{array}$ & $* * *$ \\
\hline Number of Observations & 382,063 & 382,063 & & 382,063 & & 382,063 & & 382,063 & & 382,063 & \\
\hline
\end{tabular}




\section{Table 4: The Effect of Education Spending on Household Consumption}

Notes: This table reports first stage, reduced form, and 2SLS estimates of household spending using the college-entering sample that compares business outcomes of self-employed households with near college-entry age children (15-17 year olds, or "control") to that of households with college-going age (18-19 year olds, or "treatment") children. Household consumption Standard errors are clustered at the household-level and reported in parentheses. $* * * \mathrm{p}<0.01, * * \mathrm{p}<0.05, * \mathrm{p}<0.10$

\begin{tabular}{|c|c|c|c|c|c|c|c|c|c|c|c|}
\hline \multirow{2}{*}{$\begin{array}{l}\text { Outcome } \\
\text { Variables }\end{array}$} & \multirow{2}{*}{$\begin{array}{c}\text { Control } \\
\text { Mean } \\
(1)\end{array}$} & \multicolumn{7}{|c|}{ Quarter Transitions $\times \mathbb{1}($ College-going age $)$} & \multicolumn{3}{|c|}{$\begin{array}{c}\text { TSLS } \\
\text { Estimates }\end{array}$} \\
\hline & & $\begin{array}{l}\text { I to II } \\
\text { (2) }\end{array}$ & & $\begin{array}{l}\text { II to III } \\
\text { (3) }\end{array}$ & & $\begin{array}{l}\text { III to IV } \\
\text { (4) }\end{array}$ & & $\begin{array}{l}\text { IV to I } \\
\text { (5) }\end{array}$ & & (6) & \\
\hline \multicolumn{12}{|c|}{ First Stage } \\
\hline Education Spending & $\$ 354$ & $\begin{array}{l}0.248 \\
(.013)\end{array}$ & $* * *$ & $\begin{array}{l}0.409 \\
(.012)\end{array}$ & $* * *$ & $\begin{array}{l}0.335 \\
(.012)\end{array}$ & $* * *$ & $\begin{array}{l}0.346 \\
.012)\end{array}$ & & & \\
\hline \multicolumn{12}{|c|}{ Reduced Form } \\
\hline Consumption & $\$ 17,462$ & $\begin{array}{l}0.018 \\
(.002)\end{array}$ & $* * *$ & $\begin{array}{l}0.027 \\
(.002)\end{array}$ & $* * *$ & $\begin{array}{l}0.031 \\
(.002)\end{array}$ & $* * *$ & $\begin{array}{l}0.038 \\
(.002)\end{array}$ & $* * *$ & $\begin{array}{l}0.085 \\
(.003)\end{array}$ & $* * *$ \\
\hline Nondurable goods & $\$ 2,435$ & $\begin{array}{l}-0.026 \\
(.005)\end{array}$ & $* * *$ & $\begin{array}{l}-0.040 \\
(.004)\end{array}$ & $* * *$ & $\begin{array}{l}-0.024 \\
(.004)\end{array}$ & $* * *$ & $\begin{array}{l}0.001 \\
(.004)\end{array}$ & & $\begin{array}{l}-0.066 \\
(.007)\end{array}$ & $* * *$ \\
\hline Groceries & $\$ 967$ & $\begin{array}{l}-0.054 \\
(.006)\end{array}$ & $* * *$ & $\begin{array}{l}-0.061 \\
(.005)\end{array}$ & $* * *$ & $\begin{array}{l}-0.035 \\
(.005)\end{array}$ & $* * *$ & $\begin{array}{l}-0.012 \\
(.005)\end{array}$ & $* *$ & $\begin{array}{l}-0.117 \\
(.009)\end{array}$ & $* * *$ \\
\hline Durable goods & $\$ 615$ & $\begin{array}{l}0.013 \\
(.008)\end{array}$ & & $\begin{array}{l}0.017 \\
(.008)\end{array}$ & $* *$ & $\begin{array}{l}0.017 \\
(.008)\end{array}$ & $* *$ & $\begin{array}{l}0.031 \\
(.008)\end{array}$ & $* * *$ & $\begin{array}{l}0.057 \\
(.011)\end{array}$ & $* * *$ \\
\hline Services & $\$ 2,886$ & $\begin{array}{l}0.054 \\
(.003)\end{array}$ & $* * *$ & $\begin{array}{l}0.078 \\
(.003)\end{array}$ & $* * *$ & $\begin{array}{l}0.077 \\
(.003)\end{array}$ & $* * *$ & $\begin{array}{l}0.079 \\
(.003)\end{array}$ & $* * *$ & $\begin{array}{l}0.214 \\
(.006)\end{array}$ & $* * *$ \\
\hline Restaurant & $\$ 656$ & $\begin{array}{l}0.053 \\
(.006)\end{array}$ & $* * *$ & $\begin{array}{l}0.081 \\
(.005)\end{array}$ & $* *$ & $\begin{array}{l}0.080 \\
(.005)\end{array}$ & $* * *$ & $\begin{array}{l}0.080 \\
(.005)\end{array}$ & $* * *$ & $\begin{array}{l}0.219 \\
(.01)\end{array}$ & $* * *$ \\
\hline Medical & $\$ 183$ & $\begin{array}{l}0.010 \\
(.01)\end{array}$ & & $\begin{array}{l}0.019 \\
(.009)\end{array}$ & $* *$ & $\begin{array}{l}0.019 \\
(.009)\end{array}$ & $* *$ & $\begin{array}{l}0.056 \\
(.009)\end{array}$ & $* * *$ & $\begin{array}{l}0.079 \\
(.014)\end{array}$ & $* * *$ \\
\hline Utility & $\$ 1,183$ & $\begin{array}{l}-0.002 \\
(.004)\end{array}$ & & $\begin{array}{l}0.007 \\
(.004)\end{array}$ & $*$ & $\begin{array}{l}-0.002 \\
(.004)\end{array}$ & & $\begin{array}{l}0.001 \\
(.004)\end{array}$ & & $\begin{array}{l}0.006 \\
(.006)\end{array}$ & \\
\hline Mortgage & $\$ 2,270$ & $\begin{array}{l}-0.041 \\
(.015)\end{array}$ & $* * *$ & $\begin{array}{l}-0.058 \\
(.014)\end{array}$ & $* * *$ & $\begin{array}{l}-0.075 \\
(.014)\end{array}$ & $* * *$ & $\begin{array}{l}-0.051 \\
(.014)\end{array}$ & $* * *$ & $\begin{array}{l}-0.167 \\
(.021)\end{array}$ & $* * *$ \\
\hline Number of Observations & 382,063 & 382,063 & & 382,063 & & 382,063 & & 382,063 & & 382,063 & \\
\hline
\end{tabular}


Table 5: Business Effects by Exit Decisions

Notes: This table reports the business spending response over a dependent's age profile by subsample of firms that do and don't exit from self-employement. The left panel ("Stay") sample contains households that remain self-employed, and the right panel ("Exit") sample contains households that exit from self-employment at some point during my sample period. Thus, the outcomes for the "exit" sample reflect the business response before the owners exit. Standard errors are clustered at the household level and reported in parentheses. $* * * \mathrm{p}<0.01, * * \mathrm{p}<0.05, * \mathrm{p}<0.10$

\begin{tabular}{|c|c|c|c|c|c|c|c|c|c|c|c|c|c|c|c|c|}
\hline \multirow[b]{2}{*}{ Child's Age } & \multicolumn{7}{|c|}{ Stay } & \multicolumn{9}{|c|}{ Exit } \\
\hline & $\begin{array}{c}\text { Education } \\
\text { Spending } \\
\text { (1) }\end{array}$ & & $\begin{array}{c}\text { Business } \\
\text { Expenses } \\
\text { (2) }\end{array}$ & & $\begin{array}{c}\text { Business } \\
\text { Revenues } \\
\text { (3) }\end{array}$ & & $\begin{array}{c}\text { Machinery } \\
\text { (4) }\end{array}$ & & $\begin{array}{c}\text { Education } \\
\text { Spending } \\
\quad(5)\end{array}$ & & $\begin{array}{c}\text { Business } \\
\text { Expenses } \\
\text { (6) }\end{array}$ & & $\begin{array}{c}\text { Business } \\
\text { Revenues } \\
\text { (7) }\end{array}$ & & $\begin{array}{c}\text { Machinery } \\
\text { (8) }\end{array}$ & \\
\hline 18 & $\begin{array}{l}0.196 \\
(.007)\end{array}$ & $* * *$ & $\begin{array}{l}-0.010 \\
(.002)\end{array}$ & $* * *$ & $\begin{array}{l}-0.006 \\
(.002)\end{array}$ & $* * *$ & $\begin{array}{l}0.017 \\
(.004)\end{array}$ & $* * *$ & $\begin{array}{l}0.131 \\
(.020)\end{array}$ & $* * *$ & $\begin{array}{l}-0.050 \\
(.007)\end{array}$ & $* * *$ & $\begin{array}{l}-0.062 \\
(.007)\end{array}$ & $* * *$ & $\begin{array}{l}-0.047 \\
(.011)\end{array}$ & $* * *$ \\
\hline 19 & $\begin{array}{l}0.155 \\
(.006)\end{array}$ & $* * *$ & $\begin{array}{l}-0.013 \\
(.002)\end{array}$ & $* * *$ & $\begin{array}{l}-0.008 \\
(.002)\end{array}$ & $* * *$ & $\begin{array}{l}0.007 \\
(.003)\end{array}$ & $* *$ & $\begin{array}{l}0.073 \\
(.019)\end{array}$ & $* * *$ & $\begin{array}{l}-0.058 \\
(.007)\end{array}$ & $* * *$ & $\begin{array}{l}-0.068 \\
(.007)\end{array}$ & $* * *$ & $\begin{array}{l}-0.056 \\
(.011)\end{array}$ & $* * *$ \\
\hline 20 & $\begin{array}{l}0.106 \\
(.006)\end{array}$ & $* * *$ & $\begin{array}{l}-0.015 \\
(.002)\end{array}$ & $* * *$ & $\begin{array}{l}-0.008 \\
(.002)\end{array}$ & $* * *$ & $\begin{array}{l}-0.001 \\
(.003)\end{array}$ & & $\begin{array}{l}-0.005 \\
(.018)\end{array}$ & & $\begin{array}{l}-0.062 \\
(.007)\end{array}$ & $* * *$ & $\begin{array}{l}-0.071 \\
(.007)\end{array}$ & $* * *$ & $\begin{array}{l}-0.058 \\
(.011)\end{array}$ & $* * *$ \\
\hline 21 & $\begin{array}{l}0.090 \\
(.006)\end{array}$ & $* * *$ & $\begin{array}{l}-0.018 \\
(.002)\end{array}$ & $* * *$ & $\begin{array}{l}-0.011 \\
(.002)\end{array}$ & $* * *$ & $\begin{array}{l}0.002 \\
(.003)\end{array}$ & & $\begin{array}{l}0.005 \\
(.018)\end{array}$ & & $\begin{array}{l}-0.056 \\
(.007)\end{array}$ & $* * *$ & $\begin{array}{l}-0.068 \\
(.007)\end{array}$ & $* * *$ & $\begin{array}{l}-0.061 \\
(.011)\end{array}$ & $* * *$ \\
\hline 22 & $\begin{array}{l}0.039 \\
(.006)\end{array}$ & $* * *$ & $\begin{array}{l}-0.026 \\
(.002)\end{array}$ & $* * *$ & $\begin{array}{l}-0.019 \\
(.002)\end{array}$ & $* * *$ & $\begin{array}{l}-0.007 \\
(.003)\end{array}$ & $* *$ & $\begin{array}{l}-0.070 \\
(.018)\end{array}$ & $* * *$ & $\begin{array}{l}-0.063 \\
(.007)\end{array}$ & $* * *$ & $\begin{array}{l}-0.075 \\
(.007)\end{array}$ & $* * *$ & $\begin{array}{l}-0.061 \\
(.011)\end{array}$ & $* * *$ \\
\hline 23 & $\begin{array}{l}-0.024 \\
(.006)\end{array}$ & $* * *$ & $\begin{array}{l}-0.023 \\
(.002)\end{array}$ & $* * *$ & $\begin{array}{l}-0.017 \\
(.002)\end{array}$ & $* * *$ & $\begin{array}{l}-0.010 \\
(.003)\end{array}$ & $* * *$ & $\begin{array}{l}-0.097 \\
(.017)\end{array}$ & $* * *$ & $\begin{array}{l}-0.074 \\
(.007)\end{array}$ & $* * *$ & $\begin{array}{l}-0.091 \\
(.007)\end{array}$ & $* * *$ & $\begin{array}{l}-0.064 \\
(.010)\end{array}$ & $* * *$ \\
\hline 24 & $\begin{array}{l}-0.087 \\
(.006)\end{array}$ & $* * *$ & $\begin{array}{l}-0.026 \\
(.002)\end{array}$ & $* * *$ & $\begin{array}{l}-0.014 \\
(.002)\end{array}$ & $* * *$ & $\begin{array}{l}-0.015 \\
(.003)\end{array}$ & $* * *$ & $\begin{array}{l}-0.133 \\
(.017)\end{array}$ & $* * *$ & $\begin{array}{l}-0.082 \\
(.007)\end{array}$ & $* * *$ & $\begin{array}{l}-0.095 \\
(.007)\end{array}$ & $* * *$ & $\begin{array}{l}-0.069 \\
(.010)\end{array}$ & $* * *$ \\
\hline 25 & $\begin{array}{l}-0.139 \\
(.005)\end{array}$ & $* * *$ & $\begin{array}{l}-0.029 \\
(.002)\end{array}$ & $* * *$ & $\begin{array}{l}-0.018 \\
(.002)\end{array}$ & $* * *$ & $\begin{array}{l}-0.015 \\
(.003)\end{array}$ & $* * *$ & $\begin{array}{c}-0.178 \\
(.015)\end{array}$ & $* * *$ & $\begin{array}{c}-0.102 \\
(.006)\end{array}$ & $* * *$ & $\begin{array}{c}-0.106 \\
(.006)\end{array}$ & $* * *$ & $\begin{array}{l}-0.097 \\
(.010)\end{array}$ & $* * *$ \\
\hline $\begin{array}{l}\text { Number of } \\
\text { Observations }\end{array}$ & $1,557,267$ & & $1,481,397$ & & $1,481,397$ & & $1,557,267$ & & 167,762 & & 167,733 & & 167,733 & & 167,762 & \\
\hline
\end{tabular}




\section{Table 6: Consumption Effects by Exit Decisions}

Notes: This table reports the consumption response over a dependent's age profile by subsample of firms that do and don't exit from self-employement. The left panel ("Stay") sample contains households that remain self-employed, and the right panel ("Exit") sample contains households that exit from self-employment at some point during my sample period. Thus, the outcomes for the "exit" sample reflect the business response before the owners exit. Standard errors are clustered at the household level and reported in parentheses. $* * * \mathrm{p}<0.01, * * \mathrm{p}<0.05, * \mathrm{p}<0.10$

\begin{tabular}{|c|c|c|c|c|c|c|c|c|c|c|c|c|c|c|c|c|}
\hline \multirow[b]{2}{*}{ Child's Age } & \multicolumn{7}{|c|}{ Stay } & \multicolumn{9}{|c|}{ Exit } \\
\hline & $\begin{array}{c}\text { Consumption } \\
\text { (1) }\end{array}$ & & $\begin{array}{c}\text { Groceries } \\
\text { (2) }\end{array}$ & & $\begin{array}{c}\text { Restaurants } \\
\text { (3) }\end{array}$ & & $\begin{array}{c}\text { Medical } \\
\text { (4) }\end{array}$ & & $\begin{array}{c}\text { Consumption } \\
\text { (5) }\end{array}$ & & $\begin{array}{c}\text { Groceries } \\
\text { (6) }\end{array}$ & & $\begin{array}{l}\text { Restaurants } \\
\text { (7) }\end{array}$ & & $\begin{array}{c}\text { Medical } \\
(8)\end{array}$ & \\
\hline 18 & $\begin{array}{l}0.021 \\
(.001)\end{array}$ & $* * *$ & $\begin{array}{l}0.004 \\
(.002)\end{array}$ & $*$ & $\begin{array}{l}0.038 \\
(.002)\end{array}$ & $* * *$ & $\begin{array}{l}0.010 \\
(.004)\end{array}$ & $* * *$ & $\begin{array}{l}0.014 \\
(.004)\end{array}$ & $* * *$ & $\begin{array}{l}-0.013 \\
(.007)\end{array}$ & $*$ & $\begin{array}{l}0.015 \\
(.007)\end{array}$ & $* *$ & $\begin{array}{l}-0.002 \\
(.012)\end{array}$ & \\
\hline 19 & $\begin{array}{l}0.018 \\
(.001)\end{array}$ & $* * *$ & $\begin{array}{l}0.001 \\
(.002)\end{array}$ & & $\begin{array}{l}0.038 \\
(.002)\end{array}$ & $* * *$ & $\begin{array}{l}0.003 \\
(.004)\end{array}$ & & $\begin{array}{l}0.000 \\
(.004)\end{array}$ & & $\begin{array}{l}-0.027 \\
(.007)\end{array}$ & $* * *$ & $\begin{array}{l}0.002 \\
(.007)\end{array}$ & & $\begin{array}{l}-0.008 \\
(.012)\end{array}$ & \\
\hline 20 & $\begin{array}{l}0.016 \\
(.001)\end{array}$ & $* * *$ & $\begin{array}{l}0.000 \\
(.002)\end{array}$ & & $\begin{array}{l}0.037 \\
(.002)\end{array}$ & $* * *$ & $\begin{array}{l}-0.008 \\
(.004)\end{array}$ & $* *$ & $\begin{array}{l}-0.002 \\
(.004)\end{array}$ & & $\begin{array}{l}-0.030 \\
(.007)\end{array}$ & $* * *$ & $\begin{array}{l}-0.004 \\
(.007)\end{array}$ & & $\begin{array}{l}-0.056 \\
(.011)\end{array}$ & $* * *$ \\
\hline 21 & $\begin{array}{l}0.021 \\
(.001)\end{array}$ & $* * *$ & $\begin{array}{l}0.006 \\
(.002)\end{array}$ & $* * *$ & $\begin{array}{l}0.046 \\
(.002)\end{array}$ & $* * *$ & $\begin{array}{l}-0.009 \\
(.004)\end{array}$ & $* *$ & $\begin{array}{l}-0.005 \\
(.004)\end{array}$ & & $\begin{array}{l}-0.024 \\
(.007)\end{array}$ & $* * *$ & $\begin{array}{l}0.007 \\
(.007)\end{array}$ & & $\begin{array}{l}-0.045 \\
(.011)\end{array}$ & $* * *$ \\
\hline 22 & $\begin{array}{l}0.020 \\
(.001)\end{array}$ & $* * *$ & $\begin{array}{l}0.001 \\
(.002)\end{array}$ & & $\begin{array}{l}0.048 \\
(.002)\end{array}$ & $* * *$ & $\begin{array}{l}-0.019 \\
(.004)\end{array}$ & $* * *$ & $\begin{array}{l}-0.011 \\
(.004)\end{array}$ & $* * *$ & $\begin{array}{l}-0.035 \\
(.007)\end{array}$ & $* * *$ & $\begin{array}{l}-0.005 \\
(.007)\end{array}$ & & $\begin{array}{l}-0.035 \\
(.011)\end{array}$ & $* * *$ \\
\hline 23 & $\begin{array}{l}0.014 \\
(.001)\end{array}$ & $* * *$ & $\begin{array}{l}-0.009 \\
(.002)\end{array}$ & $* * *$ & $\begin{array}{l}0.041 \\
(.002)\end{array}$ & $* * *$ & $\begin{array}{l}-0.026 \\
(.004)\end{array}$ & $* * *$ & $\begin{array}{l}-0.004 \\
(.004)\end{array}$ & & $\begin{array}{l}-0.034 \\
(.007)\end{array}$ & $* * *$ & $\begin{array}{l}0.001 \\
(.007)\end{array}$ & & $\begin{array}{l}-0.064 \\
(.011)\end{array}$ & $* * *$ \\
\hline 24 & $\begin{array}{l}0.013 \\
(.001)\end{array}$ & $* * *$ & $\begin{array}{l}-0.017 \\
(.002)\end{array}$ & $* * *$ & $\begin{array}{l}0.036 \\
(.002)\end{array}$ & $* * *$ & $\begin{array}{l}-0.038 \\
(.004)\end{array}$ & $* * *$ & $\begin{array}{l}-0.005 \\
(.004)\end{array}$ & & $\begin{array}{l}-0.045 \\
(.007)\end{array}$ & $* * *$ & $\begin{array}{l}-0.006 \\
(.006)\end{array}$ & & $\begin{array}{l}-0.061 \\
(.011)\end{array}$ & $* * *$ \\
\hline 25 & $\begin{array}{l}0.020 \\
(.001)\end{array}$ & $* * *$ & $\begin{array}{l}-0.018 \\
(.002)\end{array}$ & $* * *$ & $\begin{array}{l}0.040 \\
(.002)\end{array}$ & $* * *$ & $\begin{array}{l}-0.035 \\
(.003)\end{array}$ & $* * *$ & $\begin{array}{l}0.001 \\
(.004)\end{array}$ & & $\begin{array}{l}-0.045 \\
(.006)\end{array}$ & $* * *$ & $\begin{array}{l}-0.004 \\
(.006)\end{array}$ & & $\begin{array}{l}-0.065 \\
(.010)\end{array}$ & $* * *$ \\
\hline $\begin{array}{l}\text { Number of } \\
\text { Observations }\end{array}$ & $1,557,267$ & & $1,557,267$ & & $1,557,267$ & & $1,557,244$ & & 167,762 & & 167,762 & & 167,762 & & 167,762 & \\
\hline
\end{tabular}




\section{Table 7: Post-Exit Consumption and Income Paths}

Notes: This table reports consumption and income paths of households that exit from self-employment using the reduced form equation 5. The table reports $\beta_{s}$, which captures the average effect of post-exit response $s$ periods after exiting. Consumption measure captures total household consumption net of education expenditure. Labor income refers to any direct deposits and payroll income from employer or payroll processor companies. Gig income refers to any income derived from participating in the online platform economy (labor, capital nontransport, and leasing platforms). UI receipt can be identified from UI inflows. Standard errors are clustered at the household level and reported in parentheses. $* * * \mathrm{p}<0.01,{ }^{*} \mathrm{p}<0.05, * \mathrm{p}<0.10$

\begin{tabular}{|c|c|c|c|c|c|c|c|c|}
\hline \multirow[b]{2}{*}{ Quarters from Exit } & \multicolumn{8}{|c|}{ Outcomes Relative to Pre-Exit Mean } \\
\hline & $\begin{array}{c}\text { Consumption } \\
\text { (1) }\end{array}$ & & $\begin{array}{l}\text { Labor } \\
\text { Income } \\
\text { (2) }\end{array}$ & & $\begin{array}{c}\text { Gig } \\
\text { Income } \\
(3)\end{array}$ & & $\begin{array}{c}\text { UI } \\
\text { Receipt } \\
\text { (4) }\end{array}$ & \\
\hline$t+1$ & $\begin{array}{l}0.110 \\
(.004)\end{array}$ & $* * *$ & $\begin{array}{l}1.122 \\
(.029)\end{array}$ & $* * *$ & $\begin{array}{l}0.776 \\
(.049)\end{array}$ & $* * *$ & $\begin{array}{l}0.000 \\
(.002)\end{array}$ & \\
\hline$t+2$ & $\begin{array}{l}0.093 \\
(.005)\end{array}$ & $* * *$ & $\begin{array}{l}1.345 \\
(.033)\end{array}$ & $* * *$ & $\begin{array}{l}0.939 \\
(.055)\end{array}$ & $* * *$ & $\begin{array}{l}0.000 \\
(.002)\end{array}$ & \\
\hline$t+3$ & $\begin{array}{l}0.117 \\
(.005)\end{array}$ & $* * *$ & $\begin{array}{l}1.585 \\
(.037)\end{array}$ & $* * *$ & $\begin{array}{l}1.003 \\
(.059)\end{array}$ & $* * *$ & $\begin{array}{l}-0.003 \\
(.002)\end{array}$ & \\
\hline$t+4$ & $\begin{array}{l}0.135 \\
(.005)\end{array}$ & $* * *$ & $\begin{array}{l}1.793 \\
(.041)\end{array}$ & $* * *$ & $\begin{array}{l}1.279 \\
(.070)\end{array}$ & $* * *$ & $\begin{array}{l}-0.004 \\
(.003)\end{array}$ & $*$ \\
\hline$t+5$ & $\begin{array}{l}0.156 \\
(.006)\end{array}$ & $* * *$ & $\begin{array}{l}1.973 \\
(.045)\end{array}$ & $* * *$ & $\begin{array}{l}1.284 \\
(.074)\end{array}$ & $* * *$ & $\begin{array}{l}0.000 \\
(.003)\end{array}$ & \\
\hline$t+6$ & $\begin{array}{l}0.171 \\
(.006)\end{array}$ & $* * *$ & $\begin{array}{l}2.178 \\
(.050)\end{array}$ & $* * *$ & $\begin{array}{l}1.329 \\
(.080)\end{array}$ & & $\begin{array}{l}0.000 \\
(.003)\end{array}$ & \\
\hline$t+7$ & $\begin{array}{l}0.183 \\
(.007)\end{array}$ & $* * *$ & $\begin{array}{l}2.383 \\
(.054)\end{array}$ & $* * *$ & $\begin{array}{l}1.485 \\
(.088)\end{array}$ & $* * *$ & $\begin{array}{l}-0.001 \\
(.003)\end{array}$ & $*$ \\
\hline$t+8$ & $\begin{array}{l}0.189 \\
(.007)\end{array}$ & $* * *$ & $\begin{array}{l}2.515 \\
(.054)\end{array}$ & $* * *$ & $\begin{array}{l}1.477 \\
(.093)\end{array}$ & $* * *$ & $\begin{array}{l}-0.005 \\
(.003)\end{array}$ & $*$ \\
\hline Number of Observations & 298,408 & & 298,408 & & 298,408 & & 298,408 & \\
\hline
\end{tabular}




\section{A Conceptual Framework}

I present a simple conceptual framework that highlights why education spending might lead to business responses of self-employed households. To fix ideas, I outline a parsimonious model that highlights the link between education spending and business outcomes in the presence of a liquidity constraint. The goal of this section is to illustrate that education spending can affect self-employed households' labor margins, or the households' decision to grow the business using personal funds or exit to become wage-earners. The model heavily draws from Evans and Jovanovic (1989) and Holtz-Eakin et al. (1994).

A small business owner $h$ with entrepreneurial ability $\theta_{h}$ operates a business that generates gross receipts of $R_{h}=\theta_{h} f\left(k_{h}\right) \epsilon$. The decreasing returns to scale production function $f(\cdot)$ uses capital $k_{h}$ (i.e., operating expense) as its only input ${ }^{18}$, and there is an idiosyncratic component to production $\epsilon \sim N\left(1, \sigma^{2}\right)$ with mean 1 and finite variance. A business owner has available personal assets $A_{h}$ that earn gross return $r$. Therefore, any remaining assets after purchasing business input $A_{h}-k_{h}$ can earn capital income. Then a business owner's net income is given by the sum of gross receipts and capital income generated by unused personal income: $Y_{h}^{E}=\theta_{h} f\left(k_{h}\right) \epsilon+r\left(A_{h}-k_{h}\right) .{ }^{19}$ If a business owner does not have enough personal assets to buy capital inputs (i.e., liquidity constrained), she can borrow from financial markets, but only up to a point $k_{h} \leq \Phi\left(A_{h}\right)$. The borrowing capacity $\Phi\left(A_{h}\right)$ is imposed by imperfect financial markets, and the size of the capacity increases in the owner's personal assets such that $\Phi^{\prime}\left(A_{h}\right)>0$.

Under this condition, a business owner chooses her optimal capital $k_{h}^{*}$ by maximizing the expected net business income

$$
\begin{array}{r}
\max _{k_{h}} \mathbb{E}\left[\theta_{h} f\left(k_{h}\right) \epsilon+r\left(A_{h}-k_{h}\right)\right] \\
\text { s.t. } k_{h} \leq \Phi\left(A_{h}\right)
\end{array}
$$

The maximization leads to three possible solutions. The first solution is the case when the liquidity constraint doesn't bind. In this case, the expected marginal product of capital is equal to the gross return $r$, or $\theta_{h} f^{\prime}\left(k_{h}^{*}\right)=r$. In this case, $k_{h}^{*}$ rises with the entrepreneur's ability. The second solution is a case where liquidity constraint still does not bind, but the expected marginal product of capital falls below $r$ because of low entrepreneurial ability $\theta_{h}$. If a business owner has an outside opportunity as a wage earner and has sufficiently low $\theta_{h}$, such that the expected net income of running a business is lower than

\footnotetext{
${ }^{18} \mathrm{I}$ abstract away from labor input because more than $85 \%$ of the businesses in my sample are non-employer firms.

${ }^{19}$ By definition, $k_{h}-A_{h}$ is the amount of capital financed by borrowing.
} 
being a wage earner, $Y_{h}^{E} \leq Y_{h}^{W}=w_{h}+r A_{h}$, she exits. Finally, when the liquidity constraint binds, she sets $k_{h}^{*}=\Phi\left(A_{h}\right)$.

The solutions imply that capital input is sensitive to the change in personal assets for liquidity constrained households. For constrained households, firm's capital input increases as $A_{h}$ increases because $\frac{\partial k_{h}^{*}}{\partial A_{h}}=\Phi^{\prime}\left(A_{h}\right)>0$, while it does not change for unconstrained households: $\frac{\partial k_{h}^{*}}{\partial A_{h}}=0$. Thus, $k_{h}^{*}$ becomes a function of $A_{h}$, in addition of $r$ and $\theta_{h}$, which in turn affects the revenue of the firm

$$
R_{h}=\theta_{h} f\left(k_{h}^{*}\right) \epsilon \equiv R\left(\theta_{h}, A_{h}, r, \epsilon\right)
$$

This result highlights a potential reason why education spending can affect business outcomes. Other things equal, entrepreneur's personal assets that are available to finance capital inputs are lower for households with college-entering dependents, because some of the assets will be used for education spending: $\tilde{A}_{h}=A_{h}-E_{h}$, where $\tilde{A}_{h} \leq A_{h}$ denotes personal assets for households with education payment obligations, $E_{h}$. Therefore, the decrease from $A_{h}$ to $\tilde{A}_{h}$ moves business owner's capital stock farther away from the optimal level, which in turn leads to lower business expenses, revenues, and higher exit probabilities. 


\section{B Placebo and Diagnostics}

The 2SLS identification hinges on the assumption that the instruments have a clear effect in the first stage. The strong first stage estimates reported in table 3 and the visual evidence in figure 1 of a sudden rise in spending on education at the 18 year-old-mark support this assumption. Another way to confirm the validity of my instruments is to conduct a placebo test of whether education spending increases for households with children of non-college entry age. If the interactions between quarter-to-quarter transition dummies and college-entry age dummy are valid predictors of spending on education that arises from sending kids to school, I should not detect strong first stage effects for households that do not have college-entering kids.

Table A.4 presents a placebo test that restricts the sample of self-employed households to those with children aged between 15 and 17. I compare the first stage and reduced form estimates of households with 15 year olds to 16 and 17 year olds. If the 2SLS assumptions hold, the business outcomes should not respond to a child's being 16 or 17 (i.e., not statistically different from the outcomes of the households with 15 year olds). Column 1 shows that education spending rises with a child's age. However, the magnitude of this increase is small relative to the baseline estimate of $40 \log$ points reported in table 3. Moreover, the increase in education spending is not large enough to induce large business spending response.

In addition to placebo, I run additional diagnostic tests to confirm the validity of my instruments (i.e. $Z_{h, t}=$ Quarter Transitions $\times \mathbb{1}($ College-going age $)$ ). Table A.5 reports statistics from these tests based on the 2SLS results reported in table 3. The weak instruments diagnostics tests the null hypothesis that all instruments are weak. I reject this null, confirming that my instruments are strong. The Wu-Hausman test for endogeneity confirms whether the Instrumental Variable approach is the appropriate empirical strategy- i.e., that education spending is indeed correlated with the error term in equation 1 and thus there is a need for instruments. I reject the null that $H_{0}: \operatorname{Cov}(E d, \eta)=0$, confirming the existence of endogeneity and the need for instruments. Overall, my estimates pass a placebo test as there is no first stage effect for households with dependents that are not yet college-age. A battery of diagnostic tests further confirm the validity of my instruments and identification strategy. 


\section{Figure A.1: Age Distribution of First-Year Students}

Notes: This figure reports the age distribution of first-time, full-time, first-year students in the U.S who enrolled in 2015. Age is reported as of the last day of the enrollment year (December 31, 2015). The sample is based on over 10 million students surveyed by the Cooperative Institutional Research Program at the Higher Education Research Institute (CIRP HERI) at UCLA (Eagan et al., 2016).

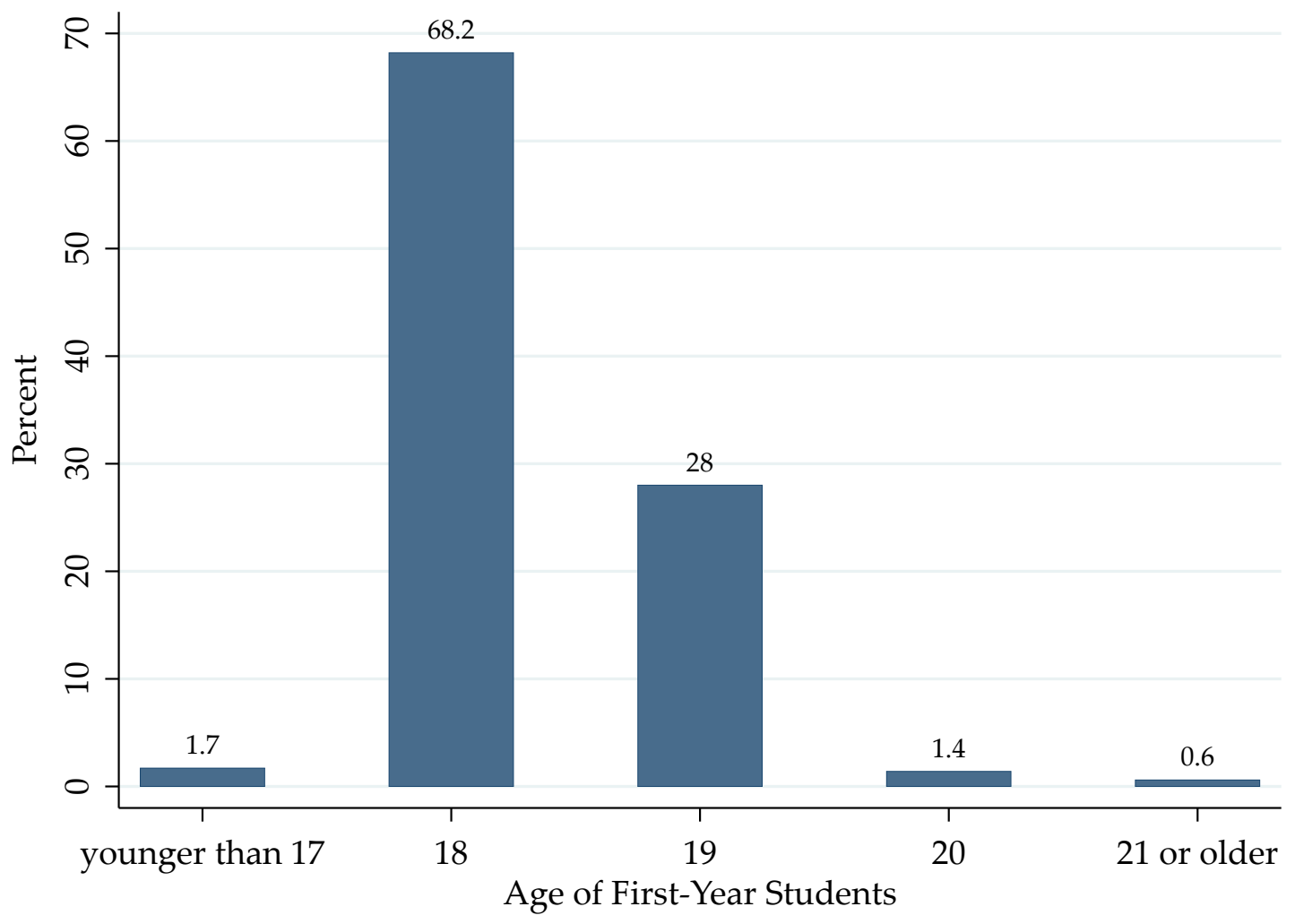




\section{Figure A.2: Business Investment and Exit Rates by Average Growth Rates}

Notes: This figure plots $\beta_{a}$ of equation 4, which captures the effect of self-employed households having an $a$-year old dependent on business spending on machineries and exit rates by businesses with different growth propensities. Business growth rates are calculated as the average year-over-year revenue growth before a child turns 18 years old. Self-employed households are grouped into quartile bins by average growth rates. Bin 1 includes firms that has the lowest pre-18 average growth rates and bin 4 includes those with the highest pre18 growth rates. The sample is restricted to self-employed households that ever had 18 or 19 year olds during the sample period. All regressions control for the age of the business and its owner, the number of dependents in a household, business industry, state of residence, and employer status of a business. Whiskers show $95 \%$ confidence intervals.

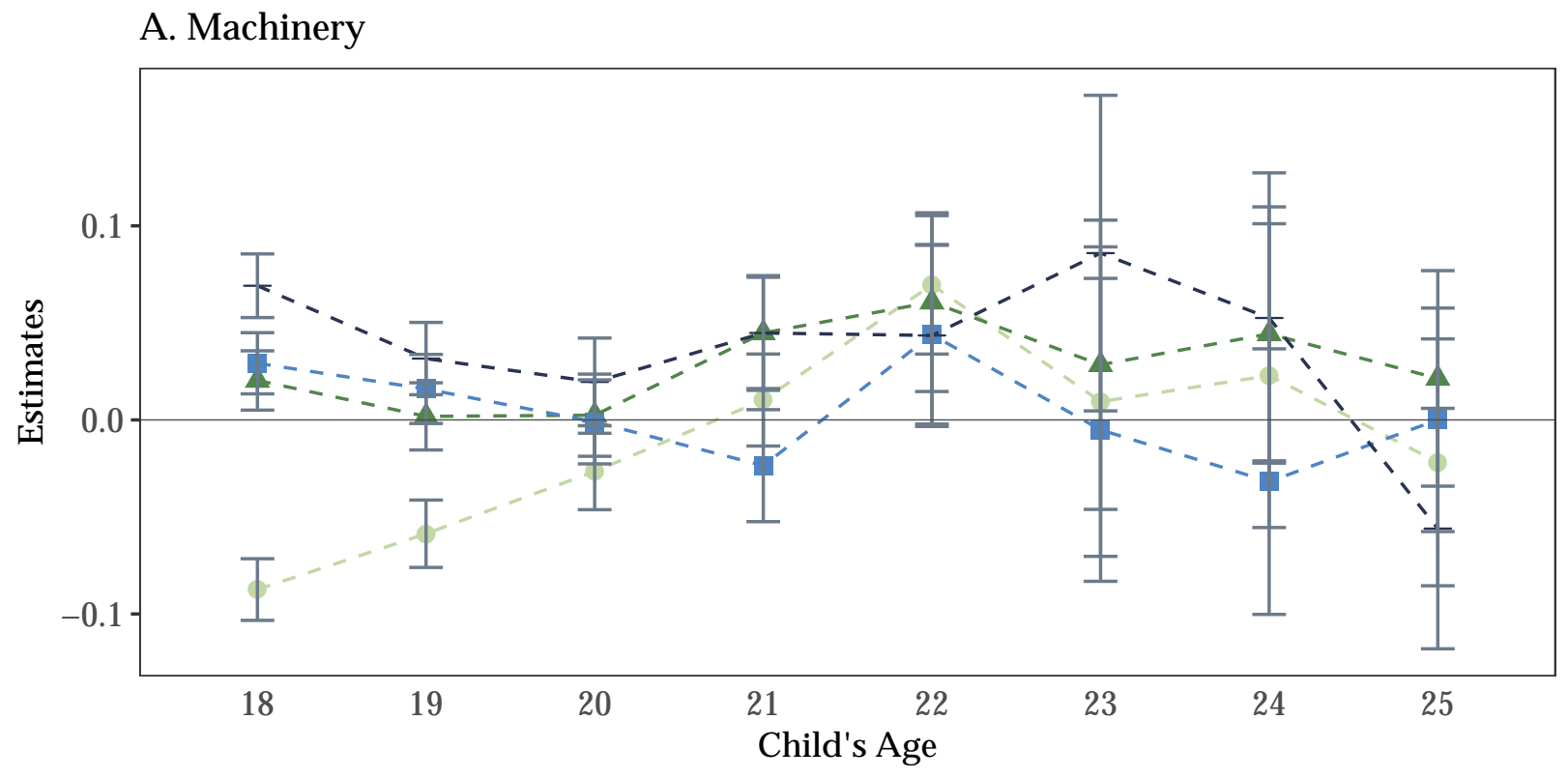

B. Exit

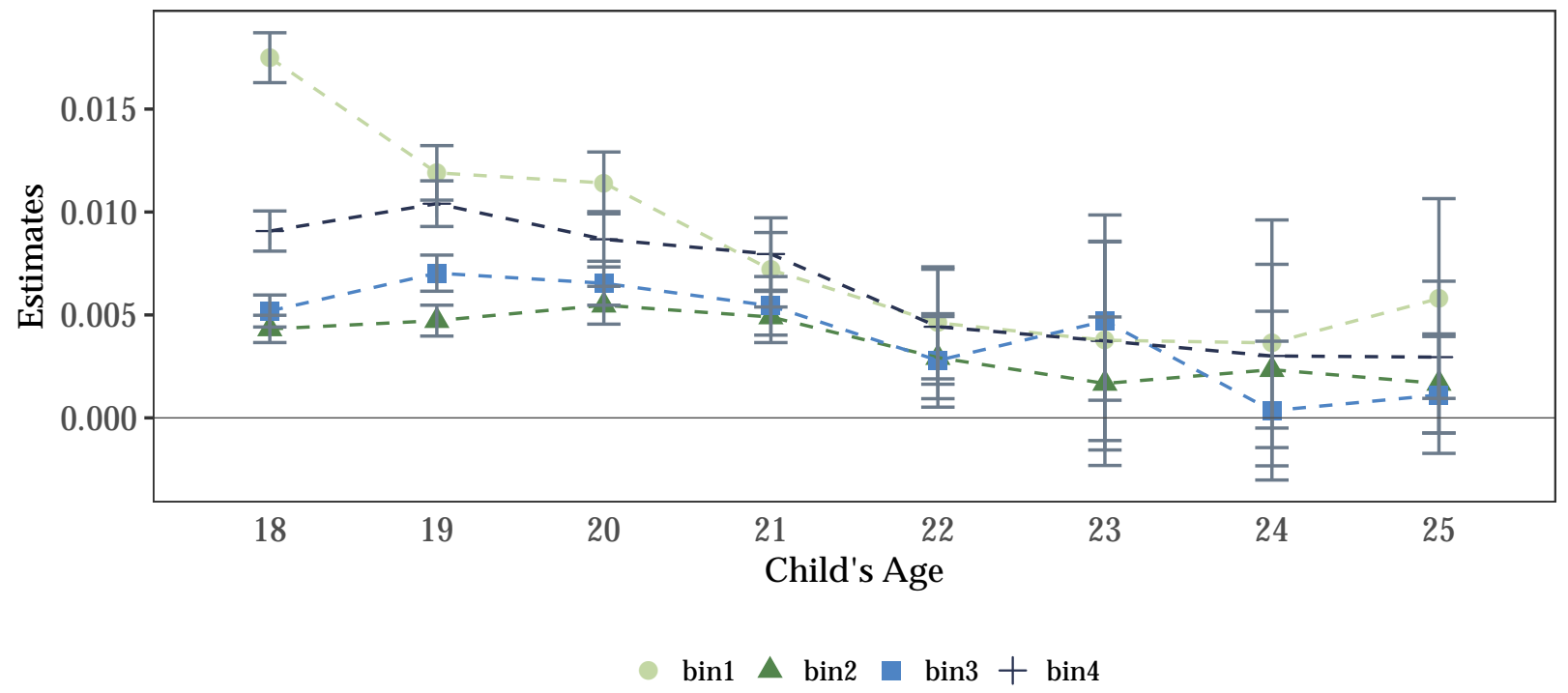




\section{Figure A.3: Household Expenditures by Average Growth Rates}

Notes: This figure plots $\beta_{a}$ of equation 4, which captures the effect of self-employed households having an $a$-year old dependent on household spending on durable goods and services net of education expenditure by businesses with different growth propensities. Business growth rates are calculated as the average year-over-year revenue growth before a child turns 18 years old. Self-employed households are grouped into quartile bins by average growth rates. Bin 1 includes firms that has the lowest pre-18 average growth rates and bin 4 includes those with the highest pre-18 growth rates. The sample is restricted to self-employed households that ever had 18 or 19 year olds during the sample period. All regressions control for the age of the business and its owner, the number of dependents in a household, business industry, state of residence, and employer status of a business. Whiskers show $95 \%$ confidence intervals.

\section{A. Durable Goods}

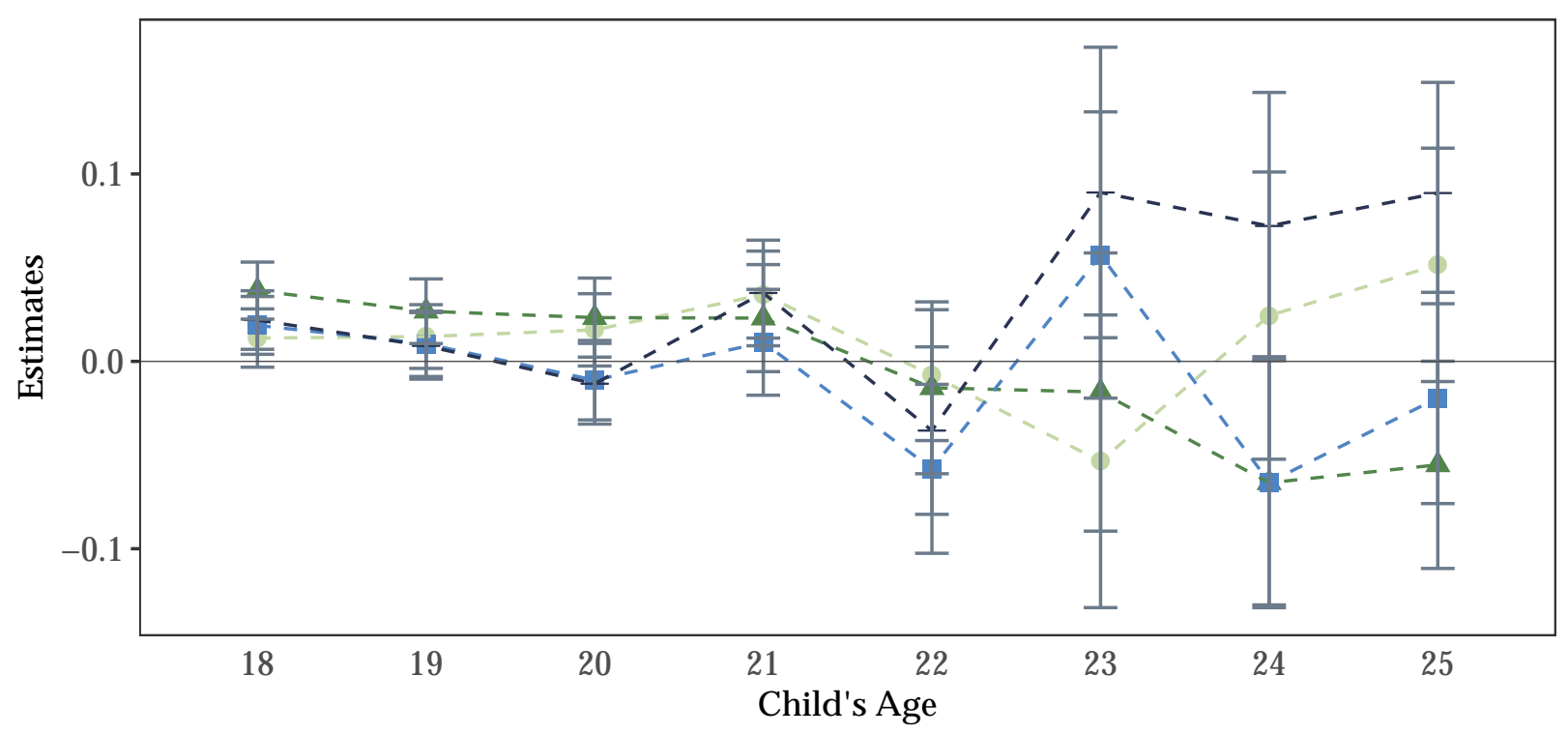

B. Services

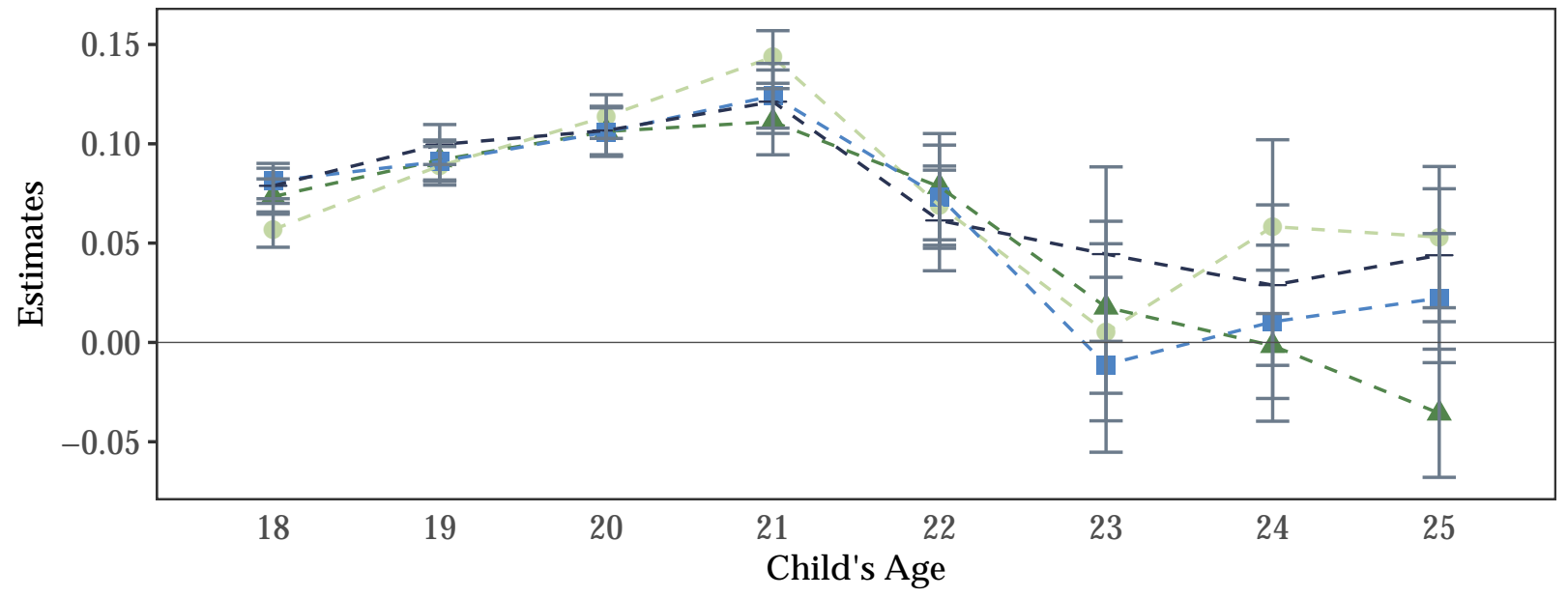

$\operatorname{bin} 1 \Delta \operatorname{bin} 2 \square \operatorname{bin} 3+\operatorname{bin} 4$ 


\section{Figure A.4: The Link between Career Choice and Business Production}

Notes: This figure plots the estimates reported in table 5 by households that do and don't exit from selfemployment. Whiskers show 95\% confidence intervals. Solid fitted lines are estimated from local regressions, and $95 \%$ confidence bands of the fitted lines are shown in grey.

A. Education Spending

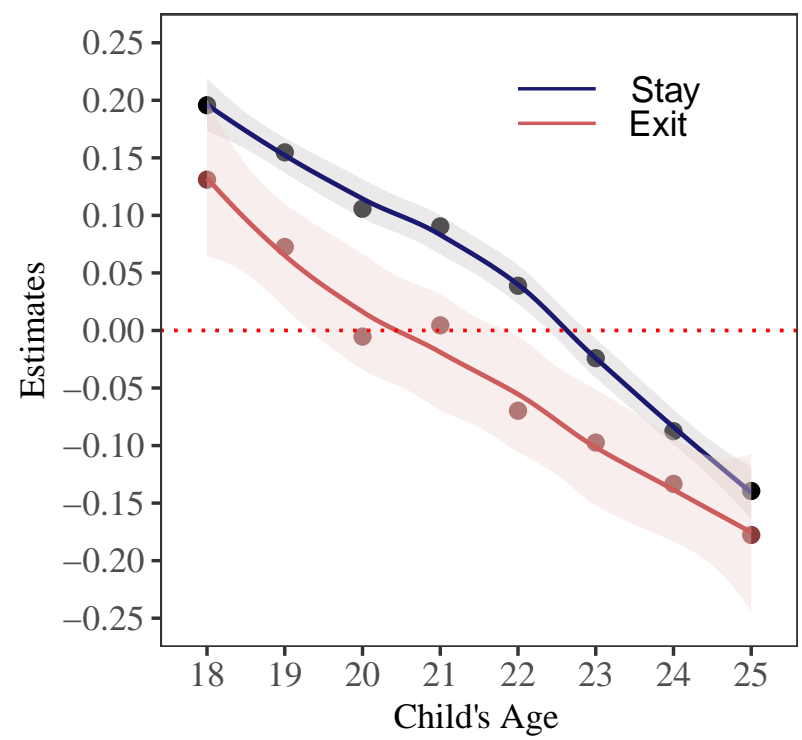

C. Revenues

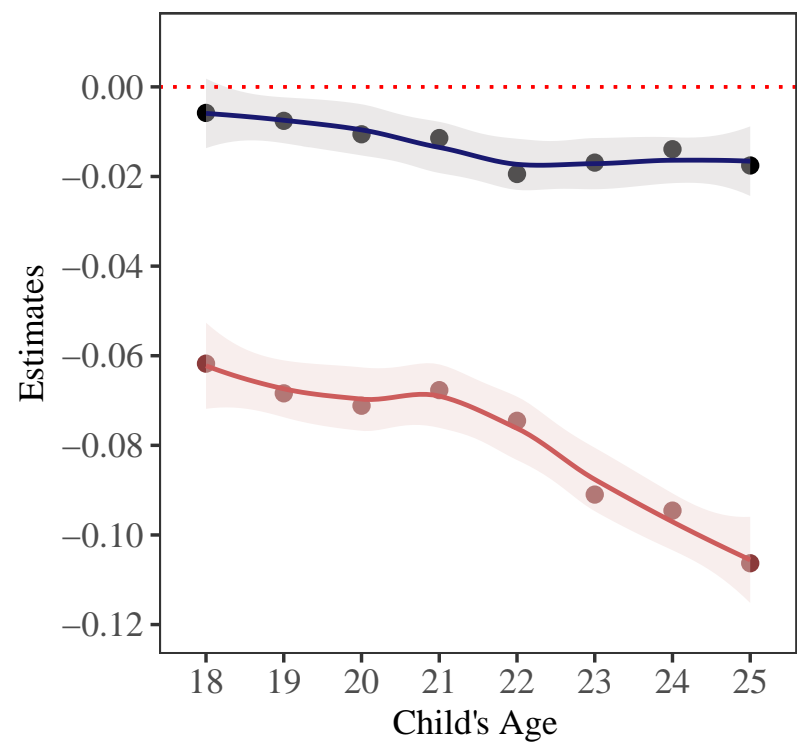

B. Expenses

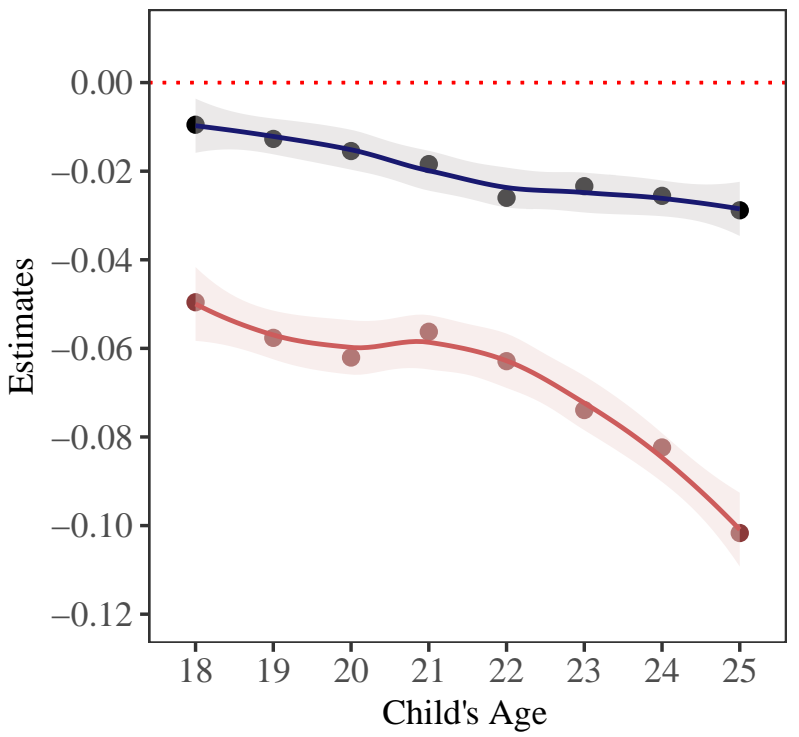

D. Machinery

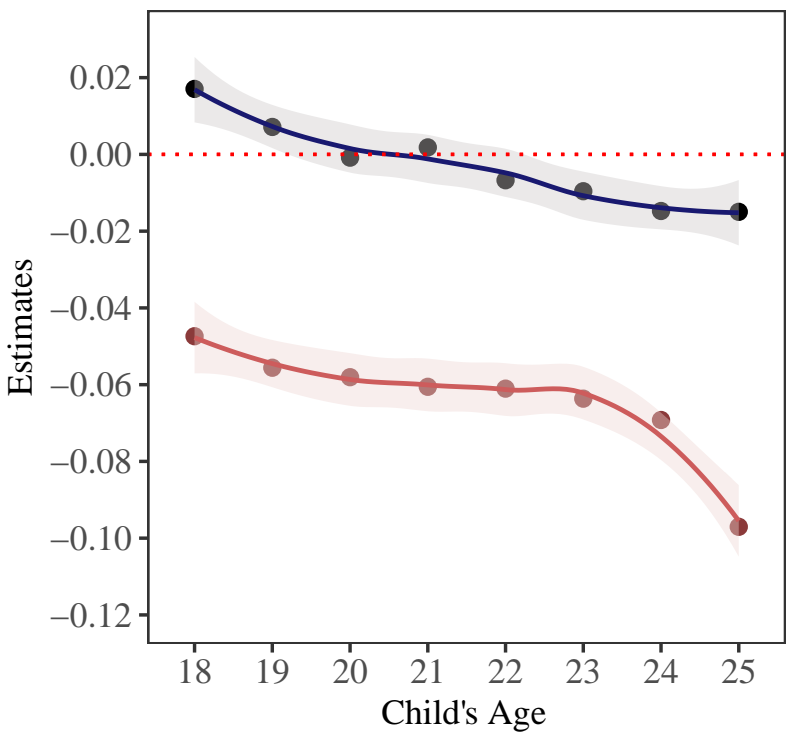




\section{Figure A.5: The Link between Career Choice and Household Consumption}

Notes: This figure plots the estimates reported in table 6 by households that do and don't exit from selfemployment. Whiskers show 95\% confidence intervals. Solid fitted lines are estimated from local regressions, and $95 \%$ confidence bands of the fitted lines are shown in grey.

A. Consumption

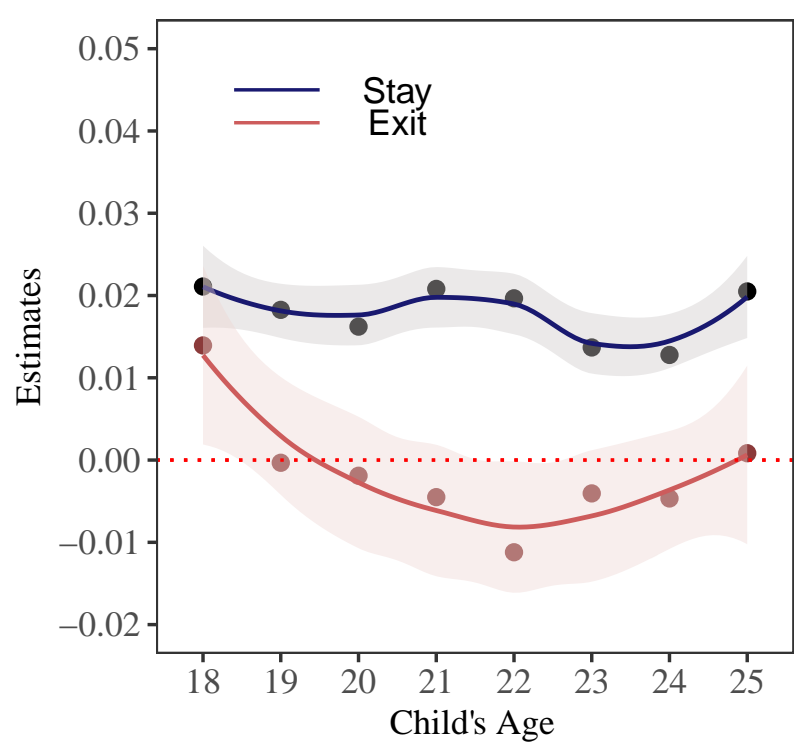

C. Restaurant

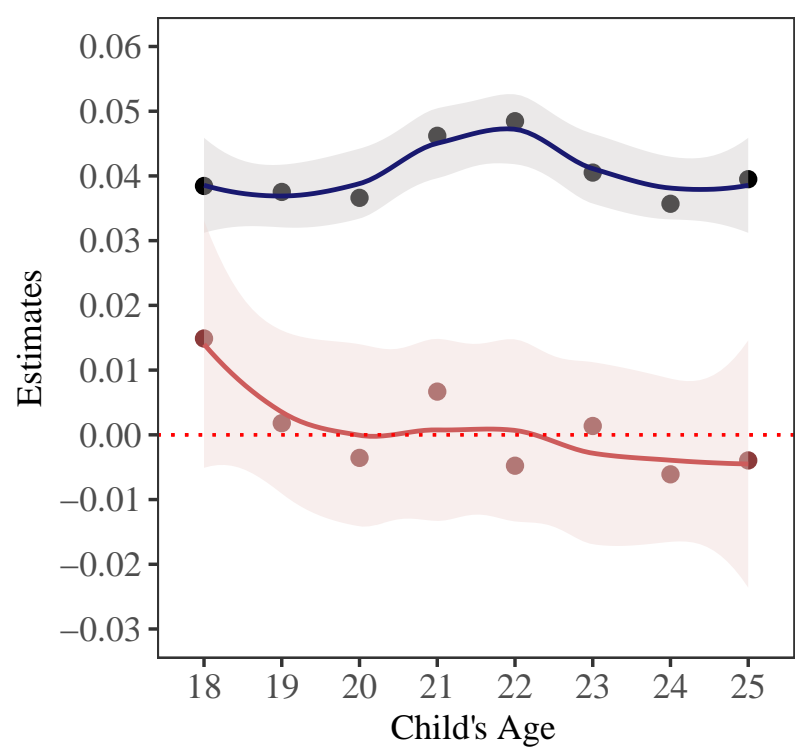

B. Groceries

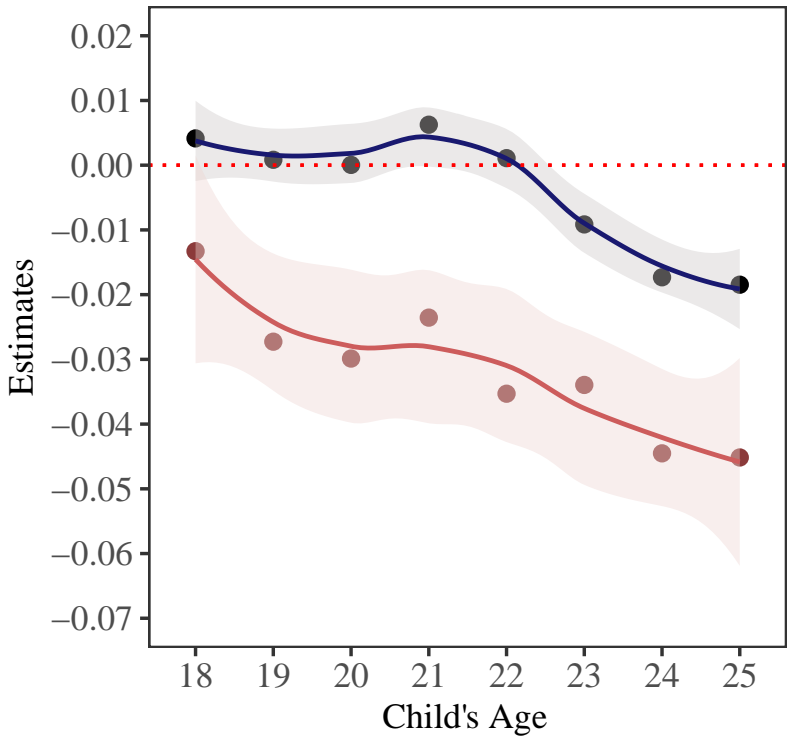

D. Medical

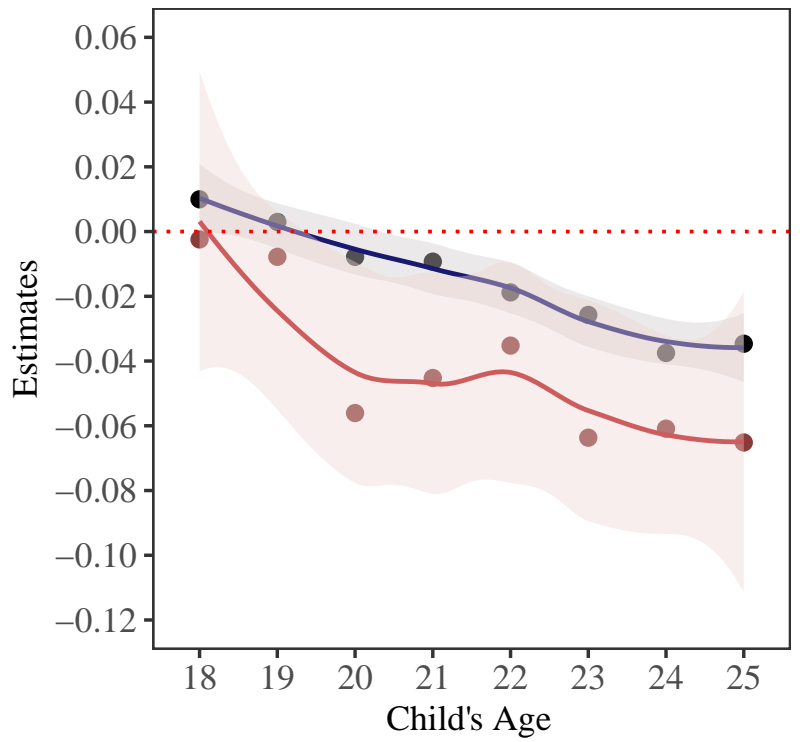




\section{Figure A.6: Exit Rates over a Child's Age Profile}

Notes: This figure plots the exit rates from self-employment over a child's age profile. The top panel plots the share of households that exit in each age bin conditional on exiting. The bottom panel plots the cumulative distribution of exit rates. Business exit is inferred from account closures or prolonged inactivity of business checking accounts in the sample period I analyze (2012 Q4 to 2018 Q2). The shaded area in grey indicates the period when the dependents are most likely to be enrolled in college (18-23).

\section{A. Exit Share by Age}

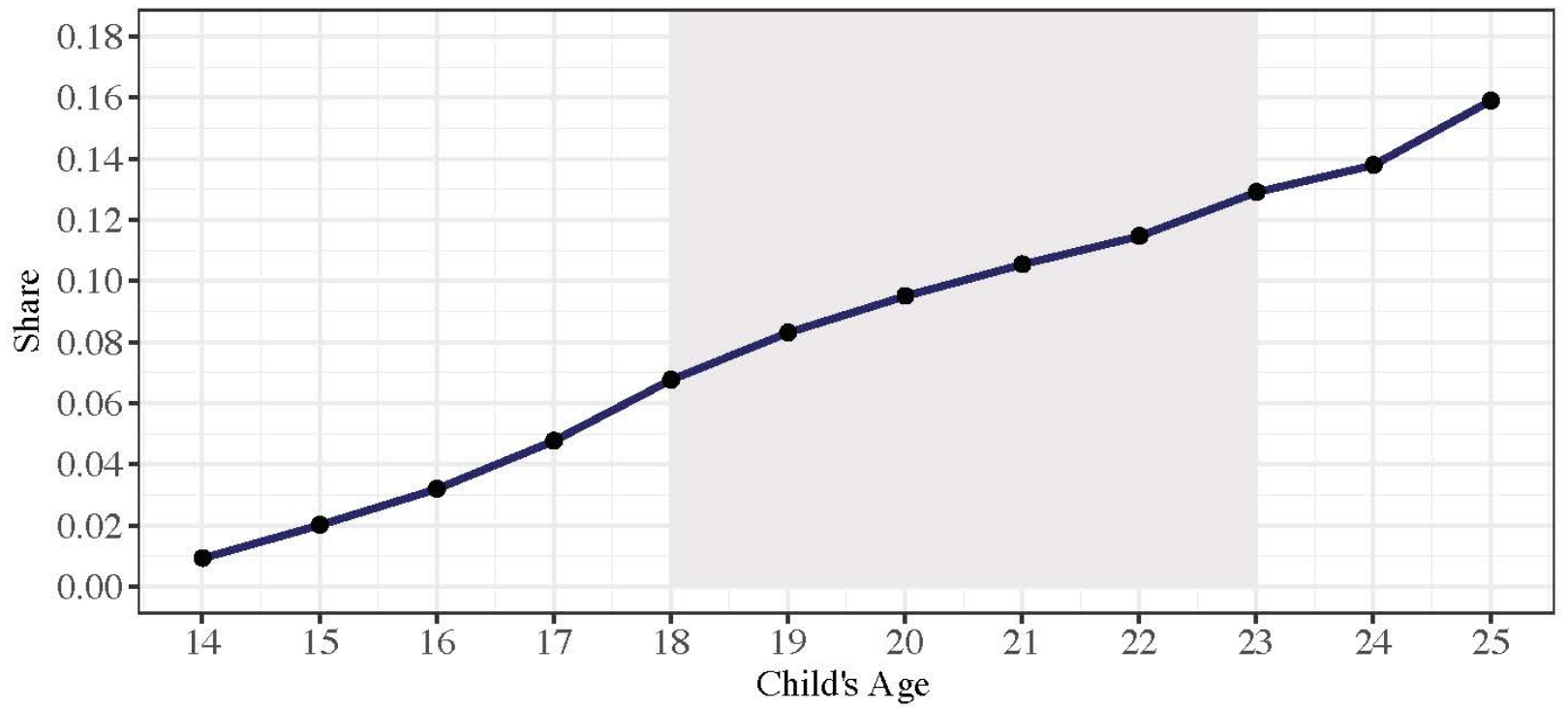

B. Cumulative Exit

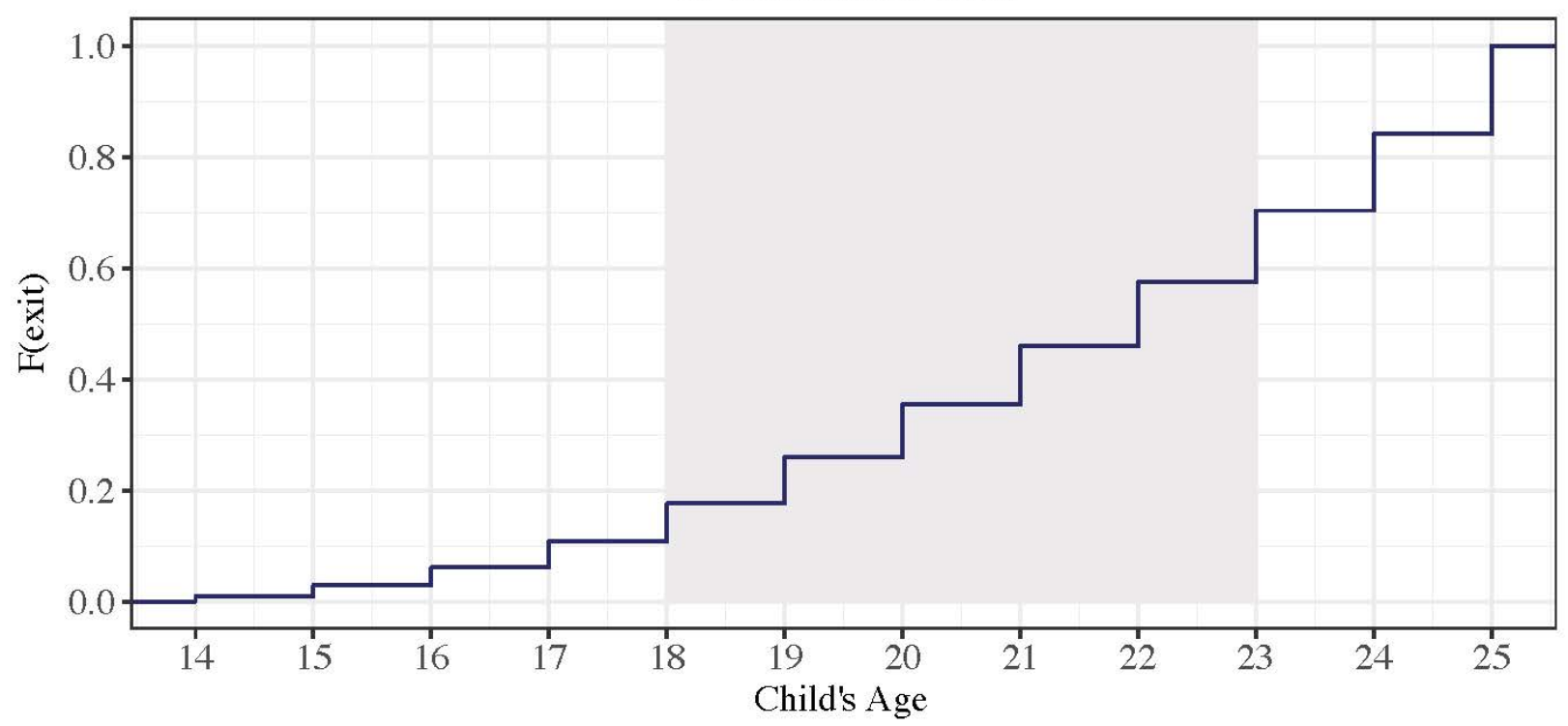




\section{Table A.1: Tuition Payment Types}

Notes: This table reports the breakdown of tuition payment types made to a mid-sized research university in the Northeast for the fiscal years 2013 and 2018. Check payments include any paper checks made from students' or parents' bank or 529 account. Other category includes tuition paid through scholarships or lockbox transfers. Wire transfers are all other online payment types excluding check or other payment types.

\begin{tabular}{lcccc}
\hline & \multicolumn{2}{c}{ Fiscal Year 2013 } & \multicolumn{2}{c}{ Fiscal Year 2018 } \\
& $\%$ of Transactions & $\%$ of Dollars (\$) & $\%$ of Transactions & $\%$ of Dollars (\$) \\
& $(1)$ & $(2)$ & $(3)$ & $(4)$ \\
\hline Wire & $87 \%$ & $78 \%$ & $89 \%$ & $81 \%$ \\
Check & $5 \%$ & $10 \%$ & $6 \%$ & $17 \%$ \\
Other & $8 \%$ & $12 \%$ & $5 \%$ & $3 \%$ \\
\hline \hline
\end{tabular}




\section{Table A.2: Comparing Near-College Entering and College-Entering Households}

Notes: This table reports the average characteristics of self-employed households with near-college entering dependents (ages 15-17) that make up the control group and those with college-entering dependents (ages 18-19) that make up the treated. Parent's age refers to the oldest member in a household and the child's age refers to the oldest child in a household. Net consumption refers to household consumption net of education spending.

\begin{tabular}{lcc}
\hline & $\begin{array}{c}\text { Control } \\
\text { Mean } \\
(1)\end{array}$ & $\begin{array}{c}\text { Treated } \\
\text { Mean } \\
(2)\end{array}$ \\
\hline Number of Family Members & 3.2 & 3.4 \\
Number of Dependents & 1.2 & 1.3 \\
Parent's Age & 50.2 & 51.9 \\
Child's Age & 15.9 & 18.5 \\
Business Years in Operation & 5.6 & 6.1 \\
Share of Employer Firms & 0.17 & 0.16 \\
Share of Households with 529 & 0.04 & 0.04 \\
Business Expenses (\$) & 66,095 & 64,399 \\
Business Revenues (\$) & 77,743 & 75,631 \\
Net Consumption $(\$)$ & 16,619 & 16,710 \\
\hline \hline
\end{tabular}




\section{Table A.3: Reduced Form Effects on Business Outcomes}

Notes: This table reports the estimated coefficients $\beta_{a}$ of the regression equation 4 . The outcomes are scaled by each household's pre-18 baseline levels if a household exists in both pre-18 and post-18 time period. Otherwise, the scaling factor is the household-specific average of the outcome. The estimates capture the effect of the dependent's age being $a$ on business outcomes of the self-employed households. Standard errors are clustered at the household level and reported in parentheses. $* * * \mathrm{p}<0.01, * * \mathrm{p}<0.05, * \mathrm{p}<0.10$

\begin{tabular}{|c|c|c|c|c|c|c|c|c|}
\hline \multirow{3}{*}{ Child's Age } & \multicolumn{7}{|c|}{ Outcomes Relative to Pre-18 Levels } & \\
\hline & $\begin{array}{l}\text { Business } \\
\text { Expenses }\end{array}$ & & $\begin{array}{l}\text { Business } \\
\text { Revenues }\end{array}$ & & Machinery & & Exit & \\
\hline & (1) & & (2) & & (3) & & (4) & \\
\hline 18 & $\begin{array}{l}-0.013 \\
(.002)\end{array}$ & $* * *$ & $\begin{array}{l}-0.011 \\
(.002)\end{array}$ & $* * *$ & $\begin{array}{l}0.011 \\
(.003)\end{array}$ & $* * *$ & $\begin{array}{c}0.002 \\
(.00)\end{array}$ & $* * *$ \\
\hline 19 & $\begin{array}{l}-0.017 \\
(.002)\end{array}$ & $* * *$ & $\begin{array}{l}-0.014 \\
(.002)\end{array}$ & $* * *$ & $\begin{array}{l}0.001 \\
(.003)\end{array}$ & & $\begin{array}{l}0.003 \\
(.00)\end{array}$ & $* * *$ \\
\hline 20 & $\begin{array}{l}-0.020 \\
(.002)\end{array}$ & $* * *$ & $\begin{array}{l}-0.017 \\
(.002)\end{array}$ & $* * *$ & $\begin{array}{l}-0.006 \\
(.003)\end{array}$ & $*$ & $\begin{array}{l}0.004 \\
(.00)\end{array}$ & $* * *$ \\
\hline 21 & $\begin{array}{l}-0.022 \\
(.002)\end{array}$ & $* * *$ & $\begin{array}{l}-0.017 \\
(.002)\end{array}$ & $* * *$ & $\begin{array}{l}-0.004 \\
(.003)\end{array}$ & & $\begin{array}{l}0.004 \\
(.00)\end{array}$ & $* * *$ \\
\hline 22 & $\begin{array}{l}-0.030 \\
(.002)\end{array}$ & $* * *$ & $\begin{array}{l}-0.025 \\
(.002)\end{array}$ & $* * *$ & $\begin{array}{l}-0.012 \\
(.003)\end{array}$ & $* * *$ & $\begin{array}{c}0.004 \\
(.00)\end{array}$ & $* * *$ \\
\hline 23 & $\begin{array}{l}-0.028 \\
(.002)\end{array}$ & $* * *$ & $\begin{array}{l}-0.024 \\
(.002)\end{array}$ & $* * *$ & $\begin{array}{l}-0.015 \\
(.003)\end{array}$ & $* * *$ & $\begin{array}{c}0.005 \\
(.00)\end{array}$ & $* * *$ \\
\hline 24 & $\begin{array}{l}-0.031 \\
(.002)\end{array}$ & $* * *$ & $\begin{array}{l}-0.022 \\
(.002)\end{array}$ & $* * *$ & $\begin{array}{l}-0.020 \\
(.003)\end{array}$ & $* * *$ & $\begin{array}{l}0.005 \\
(.00)\end{array}$ & $* * *$ \\
\hline 25 & $\begin{array}{r}-0.036 \\
(.002)\end{array}$ & $* * *$ & $\begin{array}{l}-0.027 \\
(.002)\end{array}$ & $* * *$ & $\begin{array}{c}-0.024 \\
(.003)\end{array}$ & $* * *$ & $\begin{array}{c}0.005 \\
(.00)\end{array}$ & $* * *$ \\
\hline Number of Observations & $1,649,212$ & & $1,649,212$ & & $1,649,212$ & & $1,649,212$ & \\
\hline
\end{tabular}




\section{Table A.4: Placebo}

Notes: This table reports first stage and reduced form $\beta_{t}$ restricting the sample to self-employed households with younger dependents (ages 15 - 17). The specification includes interactions of quarter transition dummies with age dummies that equals 1 if a dependent's age is 16 or 17 years old. All regressions control for baseline covariates reported in table 3. Standard errors are reported in parenthesis. $* * * \mathrm{p}<0.01, * * \mathrm{p}<0.05, * \mathrm{p}<0.10$

\begin{tabular}{|c|c|c|c|c|c|c|c|c|c|}
\hline \multirow[b]{2}{*}{$\begin{array}{l}\text { Quarter Transitions } \\
\quad \times \mathbb{1}(\text { Age }=a)\end{array}$} & \multirow{2}{*}{$\begin{array}{c}\text { First Stage } \\
\text { Education } \\
\text { spending } \\
\text { (1) }\end{array}$} & \multicolumn{8}{|c|}{ Reduced Form } \\
\hline & & & $\begin{array}{c}\text { Expense } \\
\text { (2) }\end{array}$ & & $\begin{array}{c}\text { Revenue } \\
\text { (3) }\end{array}$ & & $\begin{array}{c}\text { Machinery } \\
\text { (4) }\end{array}$ & $\begin{array}{l}\text { Exit } \\
(5)\end{array}$ & \\
\hline $\mathrm{Q} 1$ to $\mathrm{Q} 2 \times 16$ & $\begin{array}{l}0.025 \\
(.025)\end{array}$ & & $\begin{array}{l}-0.002 \\
(.006)\end{array}$ & & $\begin{array}{l}0.003 \\
(.007)\end{array}$ & & $\begin{array}{l}-0.013 \\
(.019)\end{array}$ & $\begin{array}{l}0.000 \\
(.001)\end{array}$ & \\
\hline $\mathrm{Q} 2$ to $\mathrm{Q} 3 \times 16$ & $\begin{array}{l}0.052 \\
(.022)\end{array}$ & $* *$ & $\begin{array}{l}-0.001 \\
(.005)\end{array}$ & & $\begin{array}{l}0.000 \\
(.006)\end{array}$ & & $\begin{array}{l}0.006 \\
(.016)\end{array}$ & $\begin{array}{l}0.000 \\
(.001)\end{array}$ & \\
\hline $\mathrm{Q} 3$ to $\mathrm{Q} 4 \times 16$ & $\begin{array}{l}0.059 \\
(.021)\end{array}$ & $* * *$ & $\begin{array}{l}-0.003 \\
(.005)\end{array}$ & & $\begin{array}{l}-0.001 \\
(.006)\end{array}$ & & $\begin{array}{l}0.012 \\
(.016)\end{array}$ & $\begin{array}{l}0.001 \\
(.001)\end{array}$ & \\
\hline $\mathrm{Q} 4$ to $\mathrm{Q} 1 \times 16$ & $\begin{array}{l}0.021 \\
(.026)\end{array}$ & & $\begin{array}{l}-0.006 \\
(.006)\end{array}$ & & $\begin{array}{l}-0.002 \\
(.007)\end{array}$ & & $\begin{array}{l}-0.037 \\
(.020)\end{array}$ & $\begin{array}{l}0.000 \\
(.001)\end{array}$ & \\
\hline $\mathrm{Q} 1$ to $\mathrm{Q} 2 \times 17$ & $\begin{array}{l}0.168 \\
(.024)\end{array}$ & $* * *$ & $\begin{array}{l}-0.005 \\
(.006)\end{array}$ & & $\begin{array}{l}-0.001 \\
(.007)\end{array}$ & & $\begin{array}{l}-0.024 \\
(.018)\end{array}$ & $\begin{array}{l}0.002 \\
(.001)\end{array}$ & $* *$ \\
\hline $\mathrm{Q} 2$ to $\mathrm{Q} 3 \times 17$ & $\begin{array}{l}0.232 \\
(.020)\end{array}$ & $* * *$ & $\begin{array}{l}-0.004 \\
(.005)\end{array}$ & & $\begin{array}{l}-0.005 \\
(.006)\end{array}$ & & $\begin{array}{l}-0.006 \\
(.015)\end{array}$ & $\begin{array}{c}0.000 \\
(0.001)\end{array}$ & \\
\hline $\mathrm{Q} 3$ to $\mathrm{Q} 4 \times 17$ & $\begin{array}{l}0.307 \\
(.020)\end{array}$ & $* * *$ & $\begin{array}{l}-0.012 \\
(.005)\end{array}$ & $* *$ & $\begin{array}{l}-0.015 \\
(.006)\end{array}$ & $* *$ & $\begin{array}{l}0.001 \\
(.015)\end{array}$ & $\begin{array}{l}0.002 \\
(.001)\end{array}$ & $* * *$ \\
\hline $\mathrm{Q} 4$ to $\mathrm{Q} 1 \times 17$ & $\begin{array}{l}0.145 \\
(.024)\end{array}$ & $* * *$ & $\begin{array}{l}-0.004 \\
(.006)\end{array}$ & $* *$ & $\begin{array}{l}0.000 \\
(.007)\end{array}$ & & $\begin{array}{l}-0.019 \\
(.018)\end{array}$ & $\begin{array}{l}0.001 \\
(.001)\end{array}$ & \\
\hline Number of Observations & 212,947 & & 212,947 & & 212,947 & & 212,947 & 212,947 & \\
\hline
\end{tabular}




\section{Table A.5: 2SLS Diagnostic Tests}

Notes: This table reports statistics from 2SLS diagnostic tests that validate the assumptions behind my instruments based on the 2SLS results in table 3. My instruments are Quarter Transitions $\times \mathbb{1}$ (College-going age). Weak instruments diagnostics use the first stage F-test to validate the relevance of my instruments. Wu-Hausman tests the consistency of the OLS estimates under the assumption that the IV is consistent.

\begin{tabular}{lcccccc}
\hline & \multicolumn{2}{c}{ Business Expense } & \multicolumn{2}{c}{ Business Revenues } & \multicolumn{2}{c}{ Exit } \\
& statistics & p-value & statistics & p-value & statistics & p-value \\
& $(1)$ & $(2)$ & $(3)$ & $(4)$ & $(5)$ & $(6)$ \\
\hline Weak Instruments & 744.61 & 0.00 & 744.61 & 0.00 & 744.61 & 0.00 \\
Wu-Hausman & 350.84 & 0.00 & 208.10 & 0.00 & 2.74 & 0.00 \\
\hline \hline
\end{tabular}


Table A.6: Variable Descriptions

\begin{tabular}{ll}
\hline Variable Name & Definition \\
\hline Firm & A collection of business checking accounts linked to the same owner. \\
Education Spending & $\begin{array}{l}\text { Any payments to post-secondary institutions (e.g., tuition, room, and } \\
\text { board), testing service agencies, student loan servicing companies, and } \\
\text { savings to } 529 \text { accounts. The measure does not include paper checks to } \\
\text { post-secondary institutions, room and board expenses if a student lives off- } \\
\text { campus, cost of health or dental insurance for a child, discretionary finan- } \\
\text { cial support that a family provides for a child, or additional off-the-book } \\
\text { borrowing from friends or family. }\end{array}$
\end{tabular}

Business Expense

Business Revenue

Exit

Household Consumption

Non-business income
Operating expense out of business checking accounts. Excludes financial transactions, such as transfers between accounts or fee payments, that are unlikely to capture the actual cost of operating the business. It does not include spending on education.

Operating revenues into business checking accounts. Excludes financial transactions, such as transfers between accounts or fee reversals, that are unlikely to capture the actual revenues incurred from operating the business.

A closure or inactivity of business accounts. Inactivity is defined as having less than $\$ 500$ in outflows and less than 10 transactions for 3 out of 12 consecutive months.

Any durable and non-durable spending from personal checking accounts. Consumption includes goods (e.g., groceries, fuel, home improvement, etc), services (e.g., restaurants, doctor's visits, air fares, etc), other uncategorizable bill payments using Paypal or wire transfers, utilities (e.g., phone bills, internet, cable), non-housing debt payments (auto, personal, or student loans), housing debt (HELOC, mortgages), and credit card payments.

Any income that does not come from running a business. Includes labor income (e.g., direct deposit or payroll), capital income (e.g., investment income from pensions or annuity accounts), government benefits (e.g., transfers or tax refunds), and other miscellaneous direct deposits. Transfers from business to household accounts are excluded. 